\title{
ESTIMATIVA DA EVAPOTRANSPIRAÇÃO DA BACIA DO JI-PARANÁ (RO) ATRAVÉS DE TÉCNICAS DE SENSORIAMENTO REMOTO E GEOPROCESSAMENTO
}

\author{
Daniel de Castro Victoria
}

\begin{abstract}
Dissertação apresentada à Escola Superior de Agricultura "Luiz de Queiroz", Universidade de São Paulo, para a obtenção do título de Mestre em Ecologia de Agroecossistemas.
\end{abstract}

PIRACICABA

Estado de São Paulo - Brasil

Novembro - 2004 


\title{
ESTIMATIVA DA EVAPOTRANSPIRAÇÃO DA BACIA DO JI-PARANÁ (RO) ATRAVÉS DE TÉCNICAS DE SENSORIAMENTO REMOTO E GEOPROCESSAMENTO
}

\author{
Daniel de Castro Victoria
}

Engenheiro Agrônomo

Orientadora:Profa. Dra. MARIA ViCTORIA RAMOS BALleSTER

\footnotetext{
Dissertação apresentada à Escola Superior de Agricultura "Luiz de Queiroz", Universidade de São Paulo, para a obtenção do título de Mestre em Ecologia de Agroecossistemas.
}

PIRACICABA

Estado de São Paulo - Brasil

Novembro - 2004 


\section{Dados Internacionais de Catalogação na Publicação (CIP) DIVISÃO DE BIBLIOTECA E DOCUMENTAÇÃO - ESALQ/USP}

Victoria, Daniel de Castro

Estimativa da evapotranspiração da bacia do Ji-Paraná (RO) através de técnicas de sensoriamento remoto e geoprocessamento / Daniel de Castro Victoria. - - Piracicaba, 2004.

88 p. : il.

Dissertação (Mestrado) - - Escola Superior de Agricultura Luiz de Queiroz, 2004.

Bibliografia.

1. Bacia hidrográfica 2. Balanço hídrico 3. Evapotranspiração 4. Geoprocessamento 5. Ji-Paraná, (RO) 6. Sensioramento remoto 7. Sistema de Informação Geográfica I. Título

CDD 551.572

\section{"Permitida a cópia total ou parcial deste documento, desde que citada a fonte - O autor"}


Aos meus pais, avós e minha irmã

que me moldaram na pessoa que sou hoje por minha formação pessoal e acadêmica e por me ensinar a importância do saber

dedico. 


\section{AGRADECIMENTOS}

Este trabalho não poderia ser realizado sem a ajuda e colaboração de diversas pessoas. Agradeço à Prof. Dra. Maria Victoria Ramos Ballester, pela orientação, amizade, incentivo e ensinamentos.

Ao Prof Dr. Antônio Roberto Pereira, pelos incentivos, idéias, discussões e pelo apoio ao trabalho desde o início.

Ao Dr. Jeff E. Richey, por sempre acreditar no meu trabalho e pelas oportunidades concedidas.

Ao Dr. Luiz Antonio Martinelli, pelo apoio e ensinamentos.

À ESALQ/USP, pela oportunidade concedida.

Ao Laboratório de Geoprocessamento e Tratamento de Imagens (LGTI), pelas facilidades de pesquisa.

Aos amigos e integrantes do LGTI e Laboratório de Ecologia Isotópica, Adriana, Alailson, Alex, Alexandra, André, Cátia, Fátima, José Mauro, Letícia, Marcos, Michelle, Nei, Rafael, Sérgio, Tannus, Vânia, dentre outros, pelo auxílio e amizade.

À Lílian Bellucci, pela amizade, apoio, compreensão mas horas difíceis.

Ao amigo Sílvio, pelo apoio, incentivo e amizade.

À Eliana, pela revisão das citações e formatação.

À FAPESP, pela bolsa concedida.

A todos aqueles que, de alguma forma, contribuíram para a realização deste trabalho. 


\section{SUMÁRIO}

Página

LISTA DE FIGURAS ......................................................................... vii

LISTA DE TABELAS .........................................................................

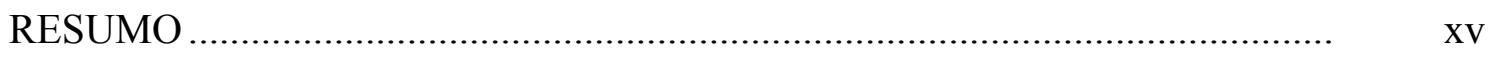

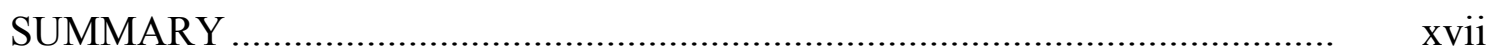

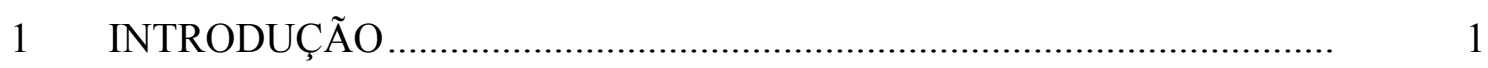

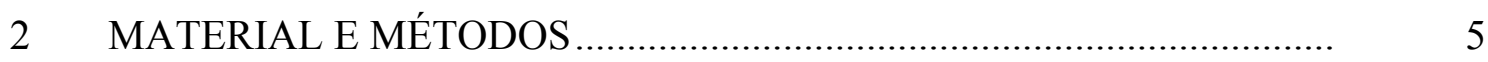

2.1 Descrição da área de estudo ............................................................ 5

2.2 Modelo de balanço hídrico de Thornthwaite-Mather................................ 6

2.3 Aquisição e interpolação dos dados pluviométricos ................................

2.4 Delimitação das sub-bacias ........................................................... 11

2.5 Balanço de massa para as sub-bacias ................................................. 12

2.6 Geração das imagens compostas mensais de temperatura da superfície .................................................................................. 13

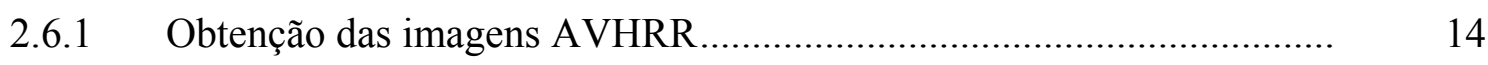

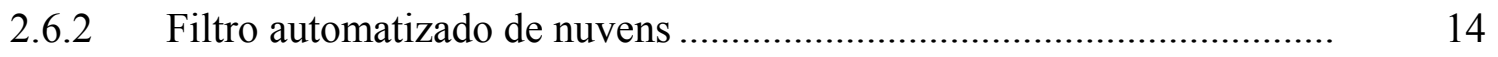

2.6.3 Cálculo da temperatura e geração da composta mensal........................ 15

2.6.4 Correção dos valores de temperatura extremos e nulos por filtros de vizinhança........................................................................... 17

2.6.5 Correção da temperatura em função do horário de passagem do satélite e elaboração das imagens compostas...................................... 
2.6.6 Correção das imagens compostas mensais de temperatura pela temperatura normal .................................................................... 22

2.7 Geração das imagens de evapotranspiração potencial .............................. 23

2.8 Capacidade de água disponível ........................................................ 25

2.8.1 Geração dos mapas de teor de argila e classe textural ........................... 26

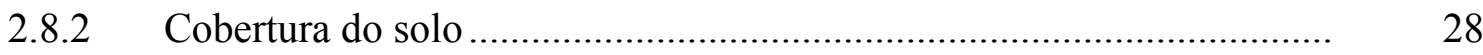

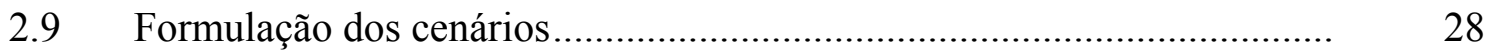

3 RESULTADOS E DISCUSSÃO........................................................ 29

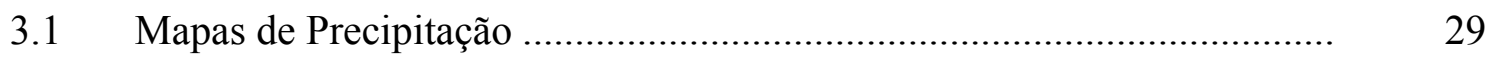

3.2 Balanço de massa nas sub-bacias......................................................... 35

3.3 Imagens compostas de temperatura .............................................. 39

3.3.1 Remoção de nuvens e média mensal das imagens diárias .................... 39

3.3.2 Correção dos valores extremos e preenchimento de falhas ................... 40

3.3.3 Correção das imagens compostas de temperatura................................. 45

3.4 Evapotranspiração potencial ............................................................. 55

3.5 Capacidade de água disponível .......................................................... 58

3.5.1 Mapa de teor de argila e classe textural ........................................... 58

3.5.2 Mapa da capacidade de água disponível (CAD) ................................. 59

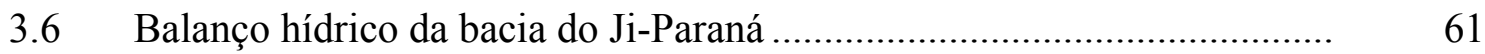

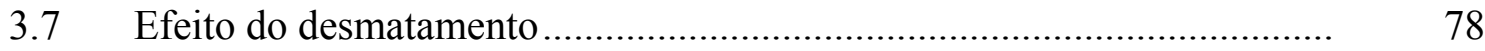

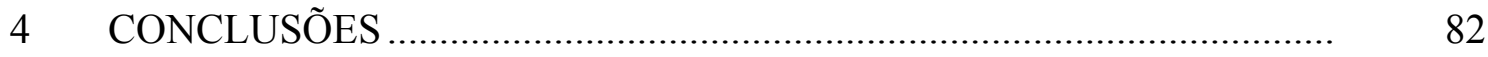

REFERÊNCIAS BIBLIOGRÁFICAS ..................................................... 84 


\section{LISTA DE FIGURAS}

Página

1 Localização da bacia de drenagem do rio Ji-Paraná, Rondônia................. 6

2 Representação esquemática de duas situações no balanço hídrico:

a) com excedente hídrico, resultando em escoamento superficial e alteração de armazenamento nulo; b) entrada de água menor que saída, acarretando em uma redução da quantidade de água armazenada no solo

3 Localização dos 36 postos pluviométricos da base da Agência Nacional de Águas utilizados no estudo da bacia do Ji-Paraná

4 Localização das estações fluviométricas na bacia do Ji-Paraná e suas respectivas sub-bacias

5 Localização das torres de medição meteorológica do projeto ABRACOS e uso do solo na bacia do Ji-Paraná em 1996

6 Relação entre a temperatura máxima e média sobre área de floresta (torre Jaru) para o período seco

7 Relação entre a temperatura máxima e média sobre área de floresta (torre Jaru) para o período chuvoso

8 Relação entre a temperatura máxima e média sobre área de pastagens (torre Nossa Senhora) para o período seco

9 Relação entre a temperatura máxima e média sobre área de pastagem (torre Nossa Senhora) para o período chuvoso 
10 Temperaturas médias mensais das duas torres meteorológicas do projeto ABRACOS (Jaru sobre floresta e Nossa Senhora sobre pastagem), juntamente com a média normal de Porto Velho, RO, para os anos de 1995 e 1996

11 Localização dos pontos amostrais de textura do solo utilizados na interpolação geoestatística

12 Imagens mensais de precipitação para o ano de 1995, obtidas pela interpolação das estações pluviométricas da ANA para a bacia do Ji-Paraná

13 Imagens mensais de precipitação para o ano de 1996, obtidas pela interpolação das estações pluviométricas da ANA para a bacia do Ji-Paraná

14 Comparação entre a precipitação normal acumulada e a média da bacia do Ji-Paraná acumulada, obtida por interpolação utilizando o método spline

15 Precipitação normal de Porto Velho e precipitações médias interpoladas para a bacia do Ji-Paraná para os anos de 1995 e 1996

16 Comparação entre a precipitação acumuladas das estações a) Theobroma, Mineração Oriente Novo, b) Fazenda Flor do Campo, Ouro Preto do Oeste, c) Mirante da Serra e Vista Alegre Br-364 com a normal de Porto Velho (RO)

17 Precipitação mensal de Março de 1995, interpolada pelo método spline (a) e pelo IDW (b). Intervalo das linhas de contorno é de 20 $\mathrm{mm}$

18 Precipitação mínima, média e máxima das superfícies de precipitação mensal interpoladas por duas metodologias diferentes, inverso da distância ao quadrado (idw) e spline 
19 Razão descarga/precipitação em relação ao desmatamento de cada sub-bacia.

20 Razão ET/precipitação em relação ao desmatamento de cada subbacia.

21 Precipitação das 10 sub-bacias em relação a porcentagem de cobertura de pasto de cada uma

22 Precipitação anual normal (média 1931 - 1990) no Brasil. Note a menor precipitação ao sul de Rondônia

23 Falsa composta colorida de imagem AVHRR sobre a bacia do Jiparaná, março de 1995 (bandas 2, 4 e 3-4)

24 Falsa composta colorida sobreposta por máscara gerada pelo algoritmo de detecção automática de nuvens

25 Curva de densidade das compostas mensais de temperatura para fevereiro de 1995, antes e após aplicação do filtro e corte da bacia. Note-se que antes da aplicação do filtro, a curva de densidade se estende para fora do gráfico.....

26 Histograma de freqüência da imagem de temperatura mensal de Fevereiro de 1995, composta a partir de imagens diárias de AVHRR, na resolução de 1 x $1 \mathrm{~km}$, para a bacia do Ji-Paraná (temperatura em ${ }^{\circ} \mathrm{C}$ )

27 Histograma de freqüência da imagem de temperatura mensal de Novembro de 1996, composta a partir de imagens diárias de AVHRR, na resolução de 1 x $1 \mathrm{~km}$, para a bacia do Ji-Paraná (temperatura em ${ }^{\circ} \mathrm{C}$ ) 
28 Temperatura média da bacia do Ji-Paraná, a partir da composta mensal do sensor AVHRR, sem a correção e com a correção devido ao horário de passagem do satélite, para os anos de 1995 e 1996. Faixa pontilhada representa o intervalo entre as temperaturas máxima e mínima normais de Porto Velho.

29 Temperaturas máxima e mínima das imagens compostas corrigidas pelo filtro de máxima vs. média (linhas contínuas), comparada as temperaturas máxima e mínima normais de Porto Velho (RO) ................

30 Temperaturas máxima, mínima e média das imagens compostas mensais corrigidas utilizando a temperatura média normal, comparadas à amplitude térmica normal e à média climatológica

31 Temperaturas máximas e mínimas das imagens compostas mensais originais, corrigidas pela relação Máx vs. Méd e corrigidas utilizando-se a média normal.

32 Imagens compostas de temperatura mensal para o ano de 1995, resolução de $1 \mathrm{~km}$ da bacia do Ji-Paraná. A imagem de outubro tem resolução de $8 \mathrm{~km}$.

33 Imagens compostas de temperatura mensal para o ano de 1996, resolução de $1 \mathrm{~km}$, da bacia do Ji-Paraná

34 Relação entre a diferença entre temperatura média sobre pastagem e floresta e a correlação espacial entre a máscara de floresta e a imagem composta de temperatura. Note que, independentemente da diferença das temperaturas médias entre as das coberturas, a correlação espacial é sempre maior para os meses secos

35 Evapotranspiração potencial (ETP) e temperatura média da bacia ao longo do período de estudo

36 Evapotranspiração potencial (ETP) modelada na bacia do Ji-Paraná pelo método de Thornthwaite para o ano de 1995 
37 Evapotranspiração potencial modelada na bacia do Ji-Paraná pelo

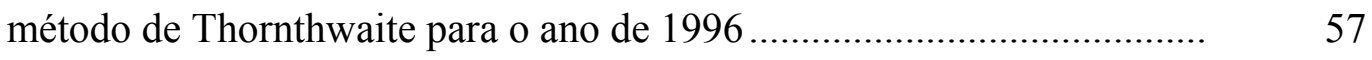

38 a) Teores de argila e b) Classes texturais da bacia do Ji-Paraná............... 59

39 Capacidade de Água disponível (CAD) da bacia do Ji-Paraná................. 60

40 Balanço hídrico modelado para a bacia do Ji-Paraná. ............................. 62

41 Balanço hídrico normal mensal para Porto Velho com CAD igual a $300 \mathrm{~mm}$

42 Temperatura média normal (1961 - 1990) para Manaus e Porto Velho.

43 Precipitação, Evapotranspiração Potencia (ETP), Evapotranspiração Real (ETr), Déficit e Excedente hídrico de outubro de 1996, modelados para a bacia do Ji-Paraná (RO).

44 Precipitação, Evapotranspiração Potencia (ETP), Evapotranspiração Real (ETr) e Déficit hídrico de julho de 1996, modelados para a bacia do Ji-Paraná (RO)

45 Balanço hídrico modelado para as sub-bacias a) Cachoeira Primavera e b) Jaru de fevereiro de 1995 a dezembro de 1996.

46 Balanço hídrico modelado para as sub-bacias a) Mineração Jacunda, b) Flor do Campo e c) Expansão de fevereiro de 1995 a dezembro de 1996.

47 Balanço hídrico modelado para as sub-bacias a) Comemoração, b) Piratininga e c) Pimenta Bueno de fevereiro de 1995 a dezembro de 1996.

48 Balanço hídrico modelado para a sub-bacia a) Tabajara e b) JiParaná de fevereiro de 1995 a dezembro de 1996 
49 Evapotranspiração real modelada vs. medida por balanço de massa para as 10 sub-bacias do Ji-Paraná. Símbolos vazios indicam sub-

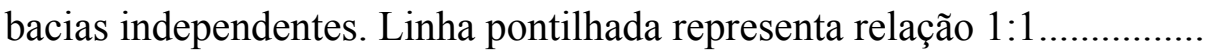

50 Excedente hídrico modelado vs. descarga observada para as 10 sub-bacias do Ji-Paraná. Símbolos vazios indicam as sub-bacias independentes. Linha pontilhada representa relação $1: 1$........................

51 Relação entre o erro da estimativa do excedente hídrico com a estimativa da evapotranspiração real

52 Erros estimados do excedente hídrico e da evapotranspiração real modelada em relação à área da sub-bacia

53 Erros estimados do excedente hídrico e da evapotranspiração real modelada em relação à CAD média da sub-bacia.

54 Evapotranspiração real média da bacia do Ji-Paraná para diferentes cenários e evapotranspiração potencial.

55 Déficit hídrico médio da bacia do Ji-Paraná para diferentes cenários

56 Excedente hídrico médio da bacia do Ji-Paraná para diferentes cenários 


\section{LISTA DE TABELAS}

Página

1 Valores médios da Capacidade de água disponível em função da textura do solo .................................................................................... 25

2 Limites para divisão das classes texturais a partir do teor de argila ..........

3 Área, porcentagem de cobertura de pasto, precipitação, vazão e evapotranspiração (ET) para cada sub-bacia da bacia do Ji-Paraná. Evapotranspiração calculada pela diferença entre precipitação e descarga. Dados referentes ao ano hidrológico de setembro de 1995 a agosto de 1996

4 Valores médio, mediano, quartis e extremos da imagem composta mensal de temperatura de fevereiro de 1995 da bacia do Ji-Paraná, antes e depois da aplicação do filtro. (em Celsius) ..................................

5 Temperaturas Mínima, Média e Máxima de cada composta mensal antes da correção para temperatura média mensal da bacia do JiParaná, expresso em Celsius

6 Temperaturas mínima, média e máxima de cada composta mensal da bacia do Ji-Paraná, expresso em Celsius

7 Temperaturas médias e desvio padrão das imagens compostas mensais nas áreas de floresta e pastagem da bacia do Ji-Paraná...............

8 Índices de correlação espacial entre as imagens compostas de temperatura e o mapa de cobertura da bacia do Ji-Paraná nos meses de fevereiro de 1995 a dezembro de 1996 
9 Evapotranspiração real e excedente hídrico para as 10 sub-bacias, comparando valores modelados e medidos ................................................ 


\title{
ESTIMATIVA DA EVAPOTRANSPIRAÇÃO DA BACIA DO JI-PARANÁ (RO) ATRAVÉS DE TÉCNICAS DE SENSORIAMENTO REMOTO E GEOPROCESSAMENTO
}

\author{
Autor: DANIEL DE CASTRO VICTORIA \\ Orientadora: Prof ${ }^{\mathrm{a}}$. Dr ${ }^{\mathrm{a}}$. MARIA VICTORIA RAMOS BALLESTER
}

\section{RESUMO}

O balanço hídrico para a bacia do Ji-Paraná (RO) nos anos de 1995 e 1996 foi modelado de modo simples, integrado a um Sistema de Informações Geográficas (SIG), utilizando como entrada, imagens de sensores remotos orbitais, dados climáticos (precipitação) e informações quanto à cobertura e o tipo de solo da bacia. Imagens diárias do sensor AVHRR foram utilizadas na geração de imagens compostas mensais de temperatura da bacia, as quais foram utilizadas na estimativa da evapotranspiração potencial mensal, através do método empírico de Thornthwaite. Estas, juntamente com mapas de precipitação interpolados a partir de postos pluviométricos, foram então utilizadas para se efetuar o balanço hídrico da bacia conforme Thornthwaite - Mather. Todo o sistema está inserido em um SIG, de forma que os resultados são espacialmente distribuídos. A evapotranspiração média da bacia foi de aproximadamente $3,2 \mathrm{~mm} \mathrm{dia}^{-1}$. A máxima ocorreu nos meses de outubro (aproximadamente $4,2 \mathrm{~mm} \mathrm{dia}^{-1}$ ), período onde se tem tanto energia e água disponível para a evapotranspiração. A mínima ocorreu no auge da estação seca, nos meses de julho e agosto (aproximadamente 1,7 mm dia ${ }^{-1}$ ). Esta sazonalidade indica que o modelo é fortemente influenciado pela disponibilidade hídrica. Os resultados obtidos com a modelagem foram comparados com o balanço de 
massa anual de 10 sub-bacias presentes na bacia do Ji-Paraná. O modelo aqui proposto sub estimou ligeiramente a evapotranspiração real (aprox $9 \%$ ), principalmente no período seco, apontando que a restrição hídrica exerce muita influência sobre os resultados. No entanto, um melhor ajuste da capacidade de armazenamento de água do solo $(\mathrm{CAD})$ pode levar a melhores resultados. 


\title{
WATER BALANCE FOR THE JI-PARANÁ BASIN (RO) USING REMOTE SENSING AND GIS
}

\author{
Author: DANIEL DE CASTRO VICTORIA \\ Adviser: Prof. MARIA VICTORIA RAMOS BALLESTER
}

\section{SUMMARY}

Water balance for the Ji-Paraná (RO) basin for 1995 and 1996 was done through a simple model, integrated into a Geographic Information System (GIS), using as input, remote sensing images, climatic data (precipitation), soils and land cover maps. Daily AVHRR images were used to obtain mean monthly temperature composites, which were converted to monthly potential evapotranspiration, using Thornthwaite's empirical formulation. Along with precipitation maps, derived from the interpolation of rain gages, the water balance was obtained according to Thornthwaite - Mather approach. All modeling was done inside a GIS, allowing for the results to be spatially distributed. Mean evapotranspiration for the basin is approximately $3.2 \mathrm{~mm}$ day $^{-1}$. Maximum evapotranspiration, close to $4.2 \mathrm{~mm} \mathrm{day}^{-1}$, occurred in October, when there is sufficient water and available energy. Minimum evapotranspiration, approximately $1.7 \mathrm{~mm} \mathrm{day}^{-1}$, occurred at the peak of the dry season, July and August. This indicates that the model is strongly influenced by water availability. The results obtained by the model were checked against annual water balances for 10 sub-basins in the Ji-Paraná basin. Evapotranspiration was sub-estimated by aprox. $9 \%$. However, a better adjustment of the water holding capacity (CAD) can lead to better results. 


\section{INTRODUÇÃO}

A água e o seu ciclo são fundamentais para o funcionamento de todos ecossistemas da Terra. Estão intimamente relacionados com o balanço energético do planeta, através da interação com a radiação solar, tanto na atmosfera, na forma de vapor e nuvens, quanto na forma líquida presente na superfície, controlando o balanço entre calor sensível e calor latente.

Porém, a água não afeta apenas o balanço de energia do planeta, atua também nos ciclos biogeoquímicos, sendo um dos principais meios de transporte de elementos e nutrientes nos ecossistemas. O ciclo hidrológico atua praticamente em todos os grandes ciclos biogeoquímmicos, seja na lixiviação do nitrogênio, no carregamento de partículas contendo fósforo, no transporte de carbono, tanto na forma orgânica quanto inorgânica, nos rios. Portanto, entender o ciclo hidrológico e, conseqüentemente o balanço hídrico, é imprescindível para o conhecimento de qualquer sistema ecológico que se pretenda estudar e manejar.

A crescente demanda por recursos hídricos, tanto no meio agrícola, através da irrigação, quanto no meio urbano, através do aumento da industrialização e dos grandes centros urbanos, faz com que a disponibilidade deste precioso recurso se torne uma preocupação crescente.

Desde o início da revolução industrial, a distribuição de água doce no planeta tem mudado como resultado direto dos esforços humanos em manejar a água e como conseqüência das alterações no uso do solo (urbano e rural) que interferem no fluxo e armazenamento da mesma (L'vovich et al., 1995).

$\mathrm{O}$ Homem encontrou vários métodos para alterar o ciclo hidrológico em seu benefício, construindo barragens para abastecimento, desviando cursos naturais e 
criando outros artificiais. No entanto, o balanço hídrico também é afetado por outras intervenções antrópicas como mudanças do uso e cobertura do solo. Estas têm efeito direto nos fluxos e compartimentos do ciclo hidrológico, modificando a capacidade de infiltração do solo, a geração de escoamento superficial e a evapotranspiração da bacia (Bruijnzeel, 1996; Ziegler et al.., 2004). Porém, tais alterações não são facilmente percebidas pela população em geral, pois além de não envolverem grandes obras, dependem muito da escala dos fenômenos. Mudanças na cobertura de pequenas bacias são mais facilmente relacionadas a alterações no regime hídrico das mesmas. Vários estudos com micro-bacias pareadas, onde uma tem sua cobertura florestal removida, comprovam que a retirada da vegetação florestal tem como conseqüência o aumento da descarga (Bosh \& Hewelett, 1989). Em estudo recente, Costa et al. (2003), analisando a série histórica de precipitação e vazão de 50 anos para uma bacia de $175.360 \mathrm{~km}^{2}$ no estado de Tocantins, mostram que tal efeito também ocorre em grandes bacias.

Dentro do balanço hídrico, a evapotranspiração tem papel fundamental, retornando para a atmosfera entre 60 a $80 \%$ da precipitação (Tateishi \& Ahn, 1996). Na bacia amazônica, em torno de 50\% da precipitação é evapotranspirada, o que significa um volume d'água cuja ordem de magnitude é de $10^{12} \mathrm{~m}^{3}$ ano $^{-1}$ (Leopoldo, 1995). Portanto, devido a sua grande participação no balanço hídrico, ações que possam alterar a intensidade da evapotranspiração, como a substituição de florestas por pastagens, a criação de reservatórios, o aumento da irrigação e abastecimento de grandes centros urbanos, podem resultar em mudanças significativas no ciclo hidrológico. Além disso, tais mudanças podem afetar as atividades humanas e até a economia local ou, dependendo da magnitude das mudanças, atingir proporções regionais e globais. Como exemplos podemos citar a redução do lago Chad, na África, que hoje apresenta apenas 1/20 do seu tamanho original, e do mar de Aral, que também vem se reduzindo devido a práticas como desvio da água para o abastecimento de cidades e irrigação (UNEP).

Medidas diretas de evapotranspiração são raras, principalmente em regiões mais afastadas de centros urbanos, pois esta não pode ser quantificada com os aparelhos comumente encontrados nas estações meteorológicas. Deve-se então lançar mão de estimativas através de modelos físicos e/ou empíricos, pois a quantificação deste 
processo é indispensável para o correto manejo hídrico local, tanto na operação de reservatórios e irrigação de áreas agrícolas, quanto em estudos de ciclos biogeoquímicos (Tucci, 1993).

A Amazônia é um dos ecossistemas mais importantes do planeta, abrangendo em torno de 5 milhões de $\mathrm{km}^{2}$ de floresta, a maior extensão de florestas tropicais do planeta. Apesar da maior parte desta região permanecer ainda intacta, o rápido desenvolvimento nas duas últimas décadas vem provocando a destruição de mais de $589 \mathrm{mil} \mathrm{km}^{2}$ de floresta apenas no Brasil (Instituto Nacional de Pesquisas Espaciais, 2001). Mudanças no uso e cobertura do solo na Amazônia, particularmente o extensivo processo de derrubada e queima, atingiram níveis considerados dramáticos entre 1985 e 1990. Estimativas das taxas de desmatamento neste período variam de 30 a $40 \mathrm{mil} \mathrm{km}^{2}$ por ano. No início da década de 90 , as taxas de desmatamento foram um pouco menores. Contudo, houve um incremento significativo em 1995, quando foram desmatados 29 mil $\mathrm{km}^{2}$. Os menores valores foram observados em $1996\left(13 \mathrm{mil} \mathrm{km}^{2}\right)$ e em 1999, voltaram ao patamar de cerca de $18 \mathrm{mil} \mathrm{km}^{2}$ (Instituto Nacional de Pesquisas Espaciais, 2001).

$\mathrm{O}$ uso e a cobertura do solo têm um papel fundamental no delineamento do ambiente em escalas global, regional e local. Mudanças no uso e cobertura do solo influenciam a diversidade biológica (Sala et al., 2000), o clima (Gash et al., 1996) e os ciclos biogeoquímicos e da água (Meixner \& Eugster, 1999). A retirada da floresta nativa pode resultar em aumentos da temperatura do solo, da erosão, em modificações do balanço hídrico e na disponibilidade de nutrientes (Vitousek \& Melillo 1979; Swank $\&$ Crossley, 1988). Conseqüentemente, o transporte para os rios de sedimentos, material orgânico e nutrientes associados é também alterado (Hunsaker \& Levine, 1995; Sharpley et al., 1995). Entender como os processos e os controles ambientais variam entre florestas nativas, planícies de inundação, áreas agrícolas e de rebrota é crucial para identificar fatores que poderão, no futuro, serem utilizados para determinar racionalmente o zoneamento agro-ecológico da região.

Neste contexto, torna-se imprescindível à utilização de modelos hidrológicos para compreender a influência do uso e cobertura no ciclo hidrológico e conseqüente resposta em todo o ecossistema. Portanto, presente trabalho teve como objetivo, estimar 
o balanço hídrico da bacia do Ji-Paraná, no estado de Rondônia, utilizando um modelo hidrológico simples, que necessite de poucos dados de entrada, inserido em um Sistema de Informações Geográficas (SIG), de forma a funcionar espacialmente, ideal para se obter estimativas rápidas da evapotranspiração de uma bacia onde não se possua muita informação. 


\section{MATERIAL E MÉTODOS}

\subsection{Descrição da área de estudo}

O rio Ji-Paraná atravessa a parte leste do estado de Rondônia, drenando uma área de aproximadamente $75400 \mathrm{~km}^{2}$, sendo formado pelos rios Comemoração e Pimenta Bueno, desembocando no rio Madeira (Figura 1). Sua bacia de drenagem se caracteriza por ser de transição, com elevada ação antrópica ao sul e menor desmatamento ao norte. A parte alta da bacia (sul) é dominada pela presença de pastagens e culturas agrícolas. Já a parte baixa da bacia, após a confluência dos rios Jaru e Machadinho, apresenta áreas com menor grau de desmatamento. Esta característica de transição permite a comparação entre os mecanismos de ciclagem de nutrientes e água sob diferentes usos do solo (Ballester et al., 2003).

A temperatura média normal da região (normal climatológica de Porto Velho, RO - INMET) está em torno de $25^{\circ} \mathrm{C}$, variando de $23,5{ }^{\circ} \mathrm{C}$ em junho a de $26{ }^{\circ} \mathrm{C}$ em outubro. A descarga média anual (1978 a 2003) no último ponto de medida (Estação Tabajara) é de $1366 \mathrm{~m}^{3} \mathrm{~s}^{-1}$.

A principal cobertura do solo na bacia, em 1996, é florestal, com $61 \%$ de sua área. Exploração agro-pastoril é responsável por $28 \%$ da cobertura da bacia enquanto que o restante está dividido em cerrado (7\%) e rebrota (3\%), sendo que a cobertura por urbanização é menor que $1 \%$ (Hanada, 2004).

As principais classes de solo da bacia são Latossolos, com 45,2 \%, Argissolos (antigos podssólicos) com 38,2 \% e Neossolos Quartzarênicos (antigas Areias Quartsozas) com 12,6 \% da bacia, estes estando mais concentrados na porção sul da bacia. 


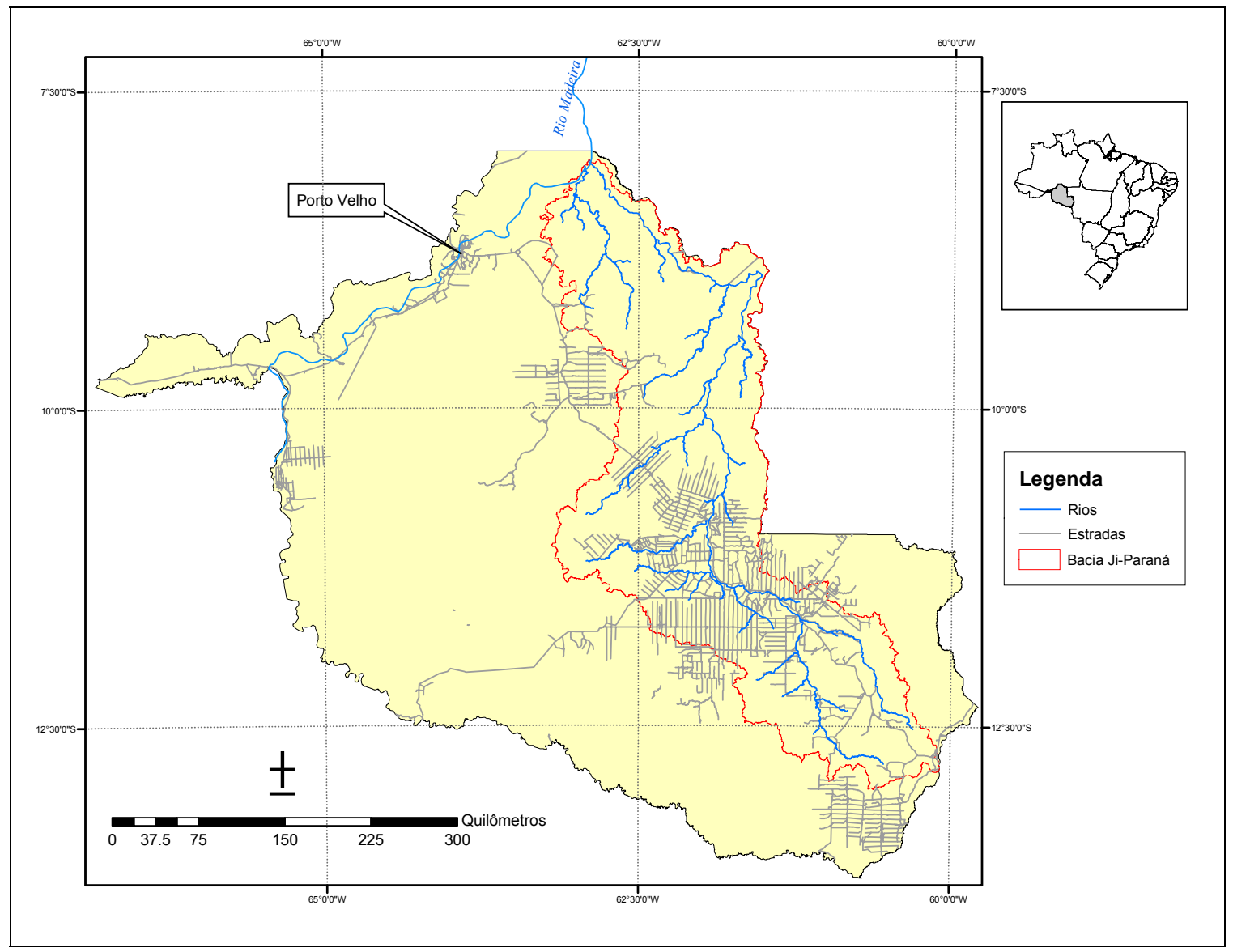

Figura 1 - Localização da bacia de drenagem do rio Ji-Paraná, Rondônia

\subsection{Modelo de balanço hídrico de Thornthwaite-Mather}

O balanço hídrico foi calculado utilizando o modelo clássico e bem difundido de Thornthwaite - Mather (1955) que utiliza como dados de entrada a evapotranspiração potencial e a precipitação (Tateishi \& Ahn, 1996). Neste modelo, considera-se que o solo possui um armazenamento máximo de água, definido pela capacidade de água disponível (CAD). Qualquer quantidade a mais de água é considerada como excedente hídrico. A retirada de água obedece a uma função exponencial, enquanto a adição é linear. Através deste modelo simples, pode-se calcular o déficit e excedente hídricos, juntamente com a alteração da quantidade de água armazenada, o armazenamento atual e 
a evapotranspiração real, apenas utilizando dados de precipitação, evapotranspiração real, textura e cobertura do solo.

As equações 1 a 8 resumem o funcionamento do modelo do balanço hídrico, juntamente com a Figura 2, que apresenta um esquema do mesmo.

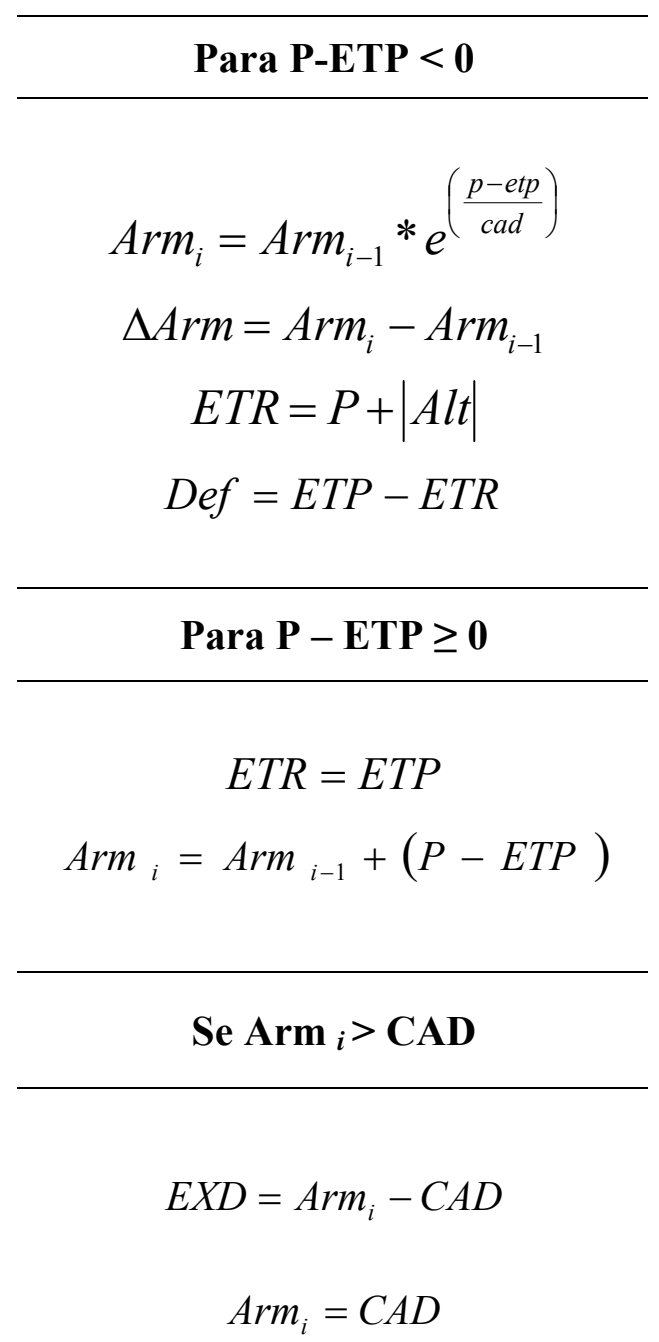




\section{$\operatorname{Arm}_{i} \geq \operatorname{Arm}_{i-1}$ \\ $P \geq E T$}

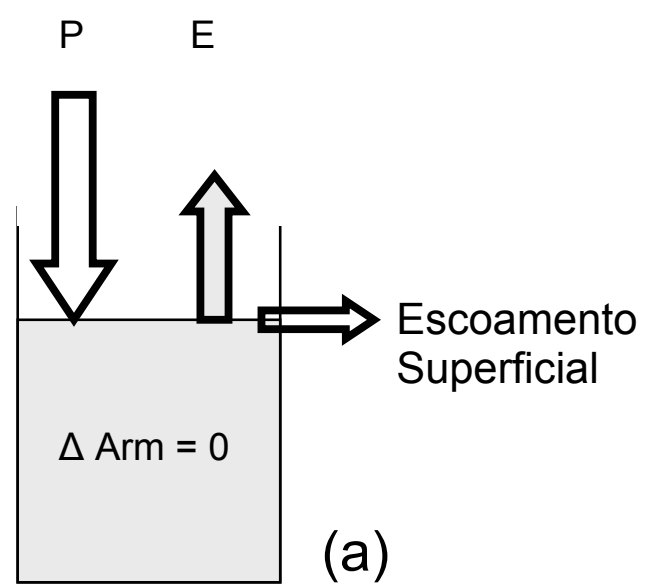

$$
\mathrm{P}<\mathrm{ET}
$$

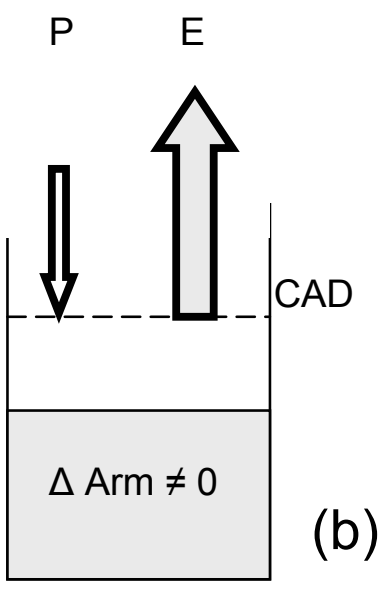

Figura 2 - Representação esquemática de duas situações no balanço hídrico: a) com excedente hídrico, resultando em escoamento superficial e alteração de armazenamento nulo; b) entrada de água menor que saída, acarretando em uma redução da quantidade de água armazenada no solo (FONTE: Tateishi \& Ahn, 1996)

Onde:

$\operatorname{Arm}_{\mathrm{i}}=$ armazenamento de água no solo no mês $i(\mathrm{~mm})$

$\mathrm{P}=$ precipitação no mês $i(\mathrm{~mm})$

$\mathrm{ETP}=$ evapotranspiração potencial no mês a $i(\mathrm{~mm})$

$\mathrm{CAD}=$ capacidade de água disponível $(\mathrm{mm})$

$\mathrm{ETR}=$ evapotranspiração real no mês a $i(\mathrm{~mm})$

$\mathrm{DEF}=$ déficit hídrico no mês $i(\mathrm{~mm})$

$\mathrm{EXD}=$ excedente hídrico no mês a $i(\mathrm{~mm})$

$\Delta \mathrm{Arm}=$ variação do armazenamento entre o mês $i-1$ e $i(\mathrm{~mm})$

Neste estudo, o modelo acima descrito foi codificado na linguagem Arc Macro Language (AML), e aplicado de forma espacializada as imagens de precipitação e de evapotranspiração potencial (ETP) da bacia do Ji-Paraná para os anos de 1995 e 1996, com resolução espacial de $1 \mathrm{~km}$ x $1 \mathrm{~km}$. A escolha dos anos em que o modelo foi rodado se baseou na disponibilidade de medidas pluviométricas e fluviométricas para a bacia do 
Ji-Paraná, juntamente com a disponibilidade de imagens do sensor AVHRR, utilizado na estimativa da temperatura média mensal.

Imagens de precipitação foram obtidas a partir da interpolação de dados observacionais de estações pluviométricas obtidas do banco de dados da Agência Nacional de Águas (ANA). Uma alternativa à interpolação de dados observacionais seria a utilização de estimativas de precipitação por satélites, como o TRMM (Tropical Rainfall Measuring Mission), ou estimativas feitas pelo GPCP (Global Precipitation Climatoligy Project), que utiliza vários sensores orbitais juntamente com dados observacionais para estimativas mensais de precipitação. No entanto, estas estimativas não puderam ser utilizadas uma vez que, os dados disponíveis para os anos de 1995 e 1996 possuem resolução espacial de 2,5 graus ( $\sim 250 \mathrm{~km}$ no equador), o que recobriria a bacia do Ji-Paraná com apenas duas células, perdendo completamente a variabilidade espacial da precipitação. Estimativas com melhor resolução espacial $(4 \mathrm{~km})$ já estão disponíveis, porém apenas a partir de 1998.

Imagens de evapotranspiração potencial foram geradas aplicando-se a metodologia de Thornthwaite (1948) a imagens compostas mensais de temperatura, obtidas a partir do sensor remoto Advanced Very High Resolution Radiometer (AVHRR), a bordo do satélite NOAA - 14 da National Oceanic and Atmospheric Administration.

Como resultado, foram obtidos mapas de Evapotranspiração Real (ETR), déficit e excedente hídricos (DEF e EXD), armazenamento no solo (ARM) e alteração da CAD (ALT).

O código fonte completo do modelo de Thornthwaite - Mather em AML pode ser obtido, entrando em contato com o autor pelo e-mail dvictori@cena.usp.br.

\subsection{Aquisição e interpolação dos dados pluviométricos}

Dados pluviométricos diários, para os anos de 1995 e 1996, de estações localizadas dentro e próximas à bacia do Ji-Paraná foram obtidos da Agência Nacional de Águas (ANA). Ao todo, 36 estações pluviométricas foram selecionadas, sendo que 
destas, 17 se encontram dentro da área de estudo (Figura 3). A partir dos valores diários de precipitação, a precipitação mensal de cada estação foi calculada. Meses com 5 ou mais dias sem observações foram descartados. Todas as estações pluviométricas foram inserida no sistema de informação geográfica (SIG) ArcGIS Desktop v. 8.1 (ESRI, 2001a), onde foi gerada uma superfície de precipitação para cada mês. A interpolação foi efetuada utilizando-se o algoritmo spline com tensão da extensão Spatial Analyst do ArcGIS. Este método, por ajustar uma superfície com curvatura mínima sobre os pontos observados, pode resultar em locais interpolados com valores negativos próximo a áreas com baixa precipitação. Tais locais foram reclassificados para 0 .

Das 36 estações, apenas 11 apresentavam registro de precipitação completo durante os anos de estudo. Na média, a interpolação foi efetuada com 34 estações por mês, sendo janeiro, abril e novembro de 1995 e janeiro de 1996 os meses com o menor número de estações utilizadas, 32 ao todo. O máximo de estações utilizadas na interpolação de um determinado mês foi 35, para os meses de junho de 1995 e junho, julho e agosto de 1996.

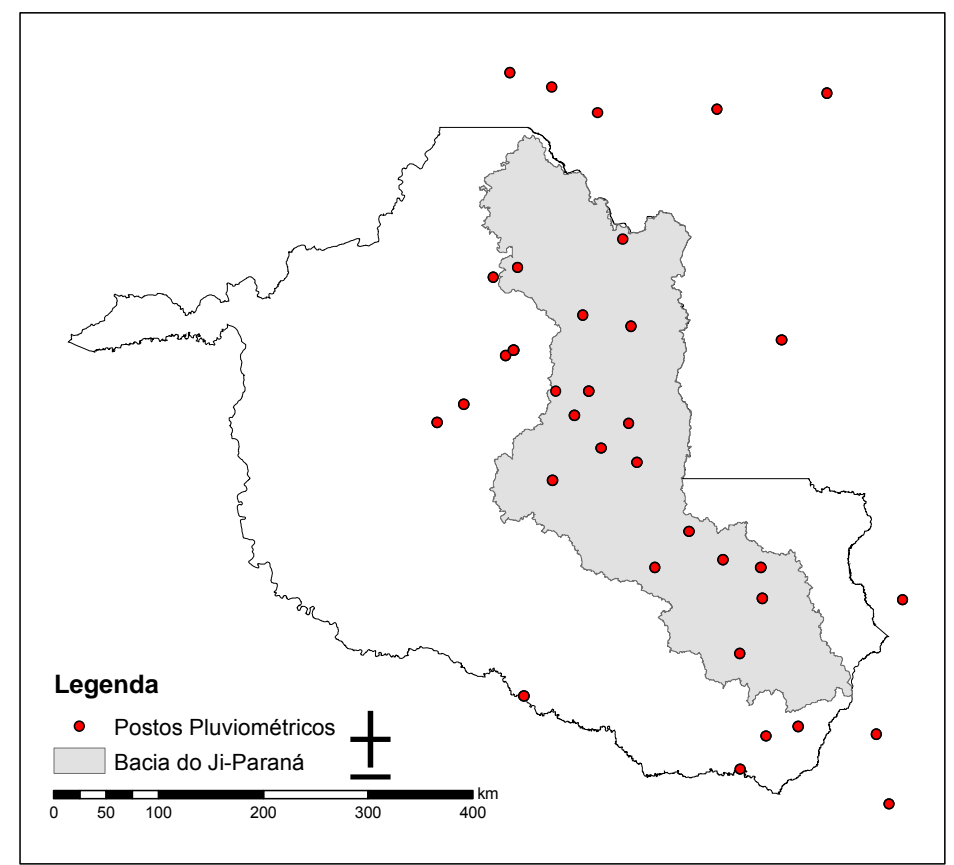

Figura 3 - Localização dos 36 postos pluviométricos da base da Agência Nacional de Águas utilizados no estudo da bacia do Ji-Paraná 


\subsection{Delimitação das sub-bacias}

A verificação do modelo de balanço hídrico foi efetuada a partir da comparação com o balanço de massa calculado para diferentes sub-bacias que contenham dados de vazão. Para calcular o balanço de massa, foram selecionadas 10 estações fluviométricas do banco de dados da ANA, localizadas dentro dos limites da bacia do rio Ji-Paraná e com dados para os anos de 1995 e 1996. A posição geográfica de cada estação foi inserida no SIG e a área de contribuição de cada ponto foi delimitada utilizando a extensão Hydrologic Modeling do SIG ArcGIS (ESRI, 2001a).

Para delimitar a área de contribuição de cada ponto foi utilizado o modelo digital de elevação do terreno (MDET), obtido do banco de dados do projeto temático em que este estudo está inserido (http://juruti.cena.usp.br). A partir do MDET calculou-se o sentido de fluxo, ou seja, a direção que um corpo d’água tomaria no terreno, bem como o acúmulo de fluxo. Em seguida, todas as células que drenam diretamente ou indiretamente para uma estação fluviométrica foram selecionadas, caracterizando assim a área de contribuição da mesma (Figura 4). 


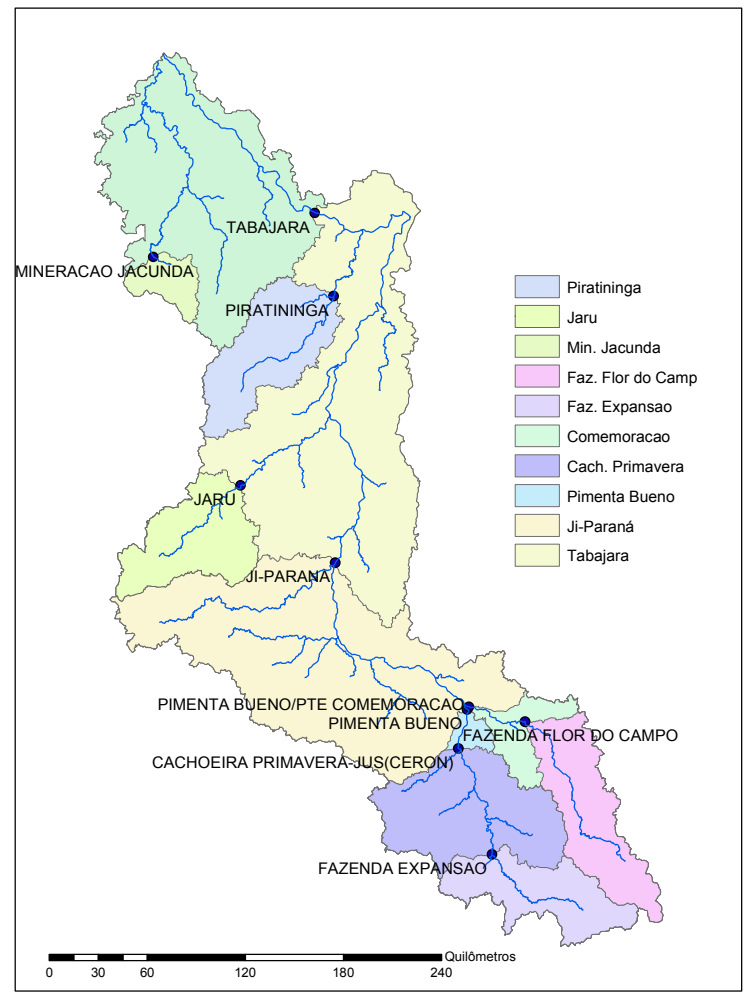

Figura 4 - Localização das estações fluviométricas na bacia do Ji-Paraná e suas respectivas sub-bacias

\subsection{Balanço de massa para as sub-bacias}

O balanço hídrico a partir do balanço de massa para cada sub-bacia foi calculado do seguinte modo:

$$
E T=P-Q \pm \Delta S
$$

onde:

ET = evapotranspiração da bacia

$\mathrm{P}=$ precipitação sobre a bacia

$\mathrm{Q}=$ descarga da bacia

$\Delta \mathrm{S}=$ variação no armazenamento do solo

Para longos períodos de tempo como um ano hidrológico, pode-se considerar a variação do armazenamento do solo como sendo desprezível, o que possibilita estimar a evapotranspiração apenas pela diferença entre a precipitação e descarga total do período (Dunne \& Leopold, 1978). Esta suposição é reforçada pela elevada precipitação da 
região (superior a $2000 \mathrm{~mm}$ ), que gera excedente hídrico e repõe o armazenamento do solo.

A precipitação total de cada sub-bacia foi calculada recortando a superfície de precipitação para cada área de contribuição e, em seguida, calculando-se o volume de chuva que caiu sobre a sub-bacia.

A comparação entre os dados do balanço de massa e do modelo utilizado no presente trabalho foi efetuada para o ano hidrológico da região (setembro-95 a agosto96), considerando que durante este período, a variação da umidade do solo é desprezível. Porém, o balanço hídrico através do modelo foi simulado utilizando passo de tempo mensal, com início em fevereiro de 1995. Considerou-se que o armazenamento de água no solo para o mês inicial era máximo. Tal consideração pode ser feita uma vez que na região, o volume das chuvas de final de ano é suficiente para completar o armazenamento. Em seguida o modelo foi rodado por 23 meses, terminando em dezembro de 1996. Este período de inicialização do modelo, de fevereiro a agosto de 1995 é necessário para que a simulação seja iniciada com o armazenamento do solo completo. Problemas no satélite NOAA 14 impossibilitaram o início do modelo em janeiro de 1995, devido à falta de imagens.

\subsection{Geração das imagens compostas mensais de temperatura da superfície}

O cálculo do balanço hídrico de forma espacializada requer a obtenção de imagens mensais de evapotranspiração potencial, as quais foram obtidas de imagens compostas mensais de temperatura para a bacia do Ji-Paraná. Estas são obtidas a partir da junção de imagens diárias do sensor AVHRR, satélite NOAA-14, na resolução de 1 x $1 \mathrm{~km}$, que recobrem a bacia de estudo. Todas as imagens diárias passaram por um filtro de detecção de nuvens automático para a remoção das mesmas e em seguida foram convertidas em imagens diárias de temperatura. Foi efetuada então a média de todas as imagens pertencentes a um mesmo mês, obtendo assim imagens compostas mensais de temperatura para a bacia do Ji-Paraná para os anos de 1995 e 1996. 


\subsubsection{Obtenção das imagens AVHRR}

Foram obtidas as 5 bandas das imagens diárias do satélite NOAA 14, sensor AVHRR, com 1 x 1 km de resolução espacial, de fevereiro de 1995 a dezembro de 1996, todas estas disponíveis gratuitamente no Satellite Active Archive da NOAA (http://www.saa.noaa.gov).

Os meses de outubro e novembro de 1995 apresentaram poucas imagens satisfatórias. Para novembro, apenas 17 imagens puderam ser utilizadas na confecção da composta, Para outubro de 1995, apenas três imagens disponíveis nos arquivos estavam em condições de uso, as quais não foram suficientes para gerar uma imagem composta mensal. Foi então utilizada a composta mensal na resolução de 8 x $8 \mathrm{~km}$ disponível para a região (http://eosdata.gsfc.nasa.gov), empregada em estudo preliminar no qual se testou o algoritmo do balanço hídrico (Victoria et. al., 2003a).

As imagens diárias foram importadas pelo programa ERDAS Imagine 8.4, o qual fez a correção geométrica das imagens automaticamente, utilizando pontos de controle disponíveis junto à imagem bruta. Também foi efetuada, de forma automatizada, a correção radiométrica das imagens, transformando os valores dos números digitais das bandas 1 e 2 em reflectância e das bandas 3 a 5 em temperatura de brilho (Brigthness Temperature).

\subsubsection{Filtro automatizado de nuvens}

O grande número de imagens utilizadas tornou obrigatória a utilização de um método automatizado de detecção de nuvens. O algoritmo adotado foi o proposto por Simpson e Gobat (1996). Existem vários outros algoritmos capazes de realizar a detecção automática de nuvens. Porém, estes se baseiam em valores limites definidos pelo operador, enquanto o método de Simpson e Gobat utiliza limites calculados a partir da própria imagem. Portanto, este método não apresenta nenhuma dependência quanto ao local da imagem, época do ano ou interpretação do usuário. 
Basicamente, o algoritmo consiste de duas etapas. Na primeira, a imagem é submetida a uma classificação não supervisionada com número de classes variável de modo a minimizar a variância dentro das classes e maximizar a variância entre as mesmas. Esta classificação funciona através de iterações onde duas classes semelhantes são unidas e aquelas com variabilidade interna elevada são separadas em cada passo. Esse processo repete-se até que o número de classes se mantenha estável, ou seja, não exista mais junção ou divisão de classes, tolerando uma variância de $5 \%$ entre dois passos consecutivos do processo de iteração. A classificação é efetuada utilizando as bandas 2 (albedo), 4 (temperatura) e a diferença da temperatura entre as bandas 3 e 4 . Em seguida, o valor central de cada classe é posicionado em um espaço tri-dimensional no qual cada eixo representa uma das 3 bandas (2, 4 e 3-4). Três limites são calculados a partir das três bandas, um para cada eixo. Estes limites, no espaço tri-dimensional, delimitam um plano, o qual divide as classes em nuvem ou não.

Todo este processo foi codificado na forma de um script capaz de funcionar no pacote de geoprocessamento e sensoriamento remoto gratuito GRASS GIS (Geographic Resources Analysis Suport System). Cada imagem diária assim processada resultou em uma imagem diária somente com áreas que não estavam cobertas por nuvens. $\mathrm{O}$ programa utilizado é disponível e pode ser obtido entrando em contato com o autor.

\subsubsection{Cálculo da temperatura e geração da composta mensal}

A temperatura da superfície foi calculada a partir das imagens diárias sem nuvens, utilizando as bandas 4 e 5 do sensor AVHRR. O cálculo foi realizado aplicando a metodologia proposta por Ulivieri em 1994, citado por Kerényi \& Putsay, 2000 (Equação 10). 
$T_{s}=T_{4}+1.8 *\left(T_{4}-T_{5}\right)+48 *(1-\varepsilon)-75 *\left(\varepsilon_{4}-\varepsilon_{5}\right)$

Onde:

Ts $=$ temperatura da superfície

$\mathrm{T} 4$ e $\mathrm{T} 5=$ temperatura de brilho para as bandas 4 e 5 respectivamente

$\varepsilon=$ média das emissividades das bandas 4 e 5

$\varepsilon_{4}$ e $\varepsilon_{5}=$ emissividade nas bandas 4 e 5 , respectivamente

As emissividades foram calculadas a partir de sua relação com o Índice da Diferença da Vegetação Normalizado (IDVN), conforme observado por Van de Griend (1993) (citado por Kerényi \& Putsay, 2000) (Equações 11 a 13).

$$
\begin{gathered}
\varepsilon_{8-14}=1.0094-0.047 * \ln (I D V N) \\
\varepsilon_{4}=\varepsilon_{8-14}-0.03 \\
\varepsilon_{5}=\varepsilon_{8-14}+0.01
\end{gathered}
$$

Onde:

$\mathcal{E}_{8-14}=$ emissividade da imagem entre 8 e $14 \mu \mathrm{m}$

$\mathcal{E}_{4}$ e $\varepsilon_{5}=$ emissividade para as bandas 4 e 5 , respectivamente

IDVN = Índice da Diferença da Vegetação Normalizado

O IDVN consiste em uma medida da atividade fotossintética da superfície e se baseia na forma em que a radiação solar é absorvida pela clorofila. Essa apresenta forte absorção nas regiões do azul e vermelho (banda 1 do sensor AVHRR) e uma alta reflexão na região do infravermelho próximo (banda 2 do sensor AVHRR). Para o sensor AVHRR, o IDVN é calculado por: 


$$
I D V N=\frac{C h 2-C h 1}{C h 2+C h 1}
$$

onde: Ch1 e Ch2 são os canais 1 e 2 do sensor AVHRR, respectivamente

Para o cálculo da emissividade (Equação 11), utilizou-se a composta mensal de IDVN, derivada pela técnica da retenção do maior valor de IDVN das imagens diárias sem nuvens.

Finalmente, as imagens de temperatura diária, sem nuvens, puderam ser calculadas pelo método de Ulivieri (Equação 10) e a composta foi obtida pela média das imagens diárias de cada mês. É importante ressaltar que o número de imagens utilizadas na composição da imagem mensal não significa, necessariamente, que todo pixel da imagem composta é calculado a partir da média de todas as imagens daquele mês. Cada pixel da imagem composta mensal representa uma média apenas dos pixeis que não estavam cobertos por nuvens nas imagens diárias. Portanto, o número de imagens utilizadas em cada pixel da imagem composta mensal é variável.

\subsubsection{Correção dos valores de temperatura extremos e nulos por filtros de vizinhança}

Algumas imagens compostas apresentaram regiões sem valor algum. Na maior parte das vezes as mesmas eram pequenas, de 3 a 5 pixeis. Isso ocorreu porque essas regiões sempre estiveram cobertas por nuvens durante o mês em que foi gerada a imagem composta. Estas áreas foram preenchidas utilizando-se um filtro de média, substituindo o valor nulo pela média dos vizinhos, utilizando-se vizinhança de 3 ou 5 células, conforme a necessidade.

Observou-se também que a maioria das imagens compostas mensais apresentavam valores muito extremos, tanto mínimos quanto máximos. Estes valores, provavelmente, resultaram da presença de células que apresentavam contaminações por nuvens, não detectadas pelo filtro por serem menores que a resolução espacial $(1$ x 1 $\mathrm{km})$. Outro fator que pode ter originado tais resultados são pixeis que não possuíam um 
número de imagens diárias suficientes. Nestes, o valor da composta era uma média de poucos dias, gerando valores extremos de temperatura.

Para a correção desses valores, primeiramente foram identificadas as células que se encontravam fora do intervalo definido pela temperatura média da imagem mais ou menos duas vezes o desvio padrão da imagem. Estes limites foram escolhidos por preservar a variação da temperatura da bacia, descartando apenas os valores muito extremos. $\mathrm{O}$ cálculo dos limites das imagens foi efetuado no programa estatístico $\mathrm{R}(R$ development core team), utilizando-se a extensão GRASS (Bivand, 2000) que permite a transferência de informações entre o SIG e o programa estatístico.

Em seguida, os píxeis que estavam fora do intervalo definido tiveram seus valores substituídos pela média dos vizinhos, aplicando um filtro de média com vizinhança de $3 \times 3$. Contudo, observou-se que mesmo após este procedimento, ainda restavam algumas células com valores fora do intervalo definido. Estes então foram substituídos usando o filtro de média com vizinhança de 5 x 5 .

\subsubsection{Correção da temperatura em função do horário de passagem do satélite e elaboração das imagens compostas}

Devido ao modo de composição das imagens de temperatura, ignorando os dias nublados, juntamente com o fato da passagem do satélite NOAA 14 ser por volta das 14:00 horas (local), as imagens de temperatura composta tendem a ser superestimadas, uma vez que, neste horário, a temperatura local é máxima.

Para corrigir esta super-estimativa, dados horários de duas torres meteorológicas do projeto Anglo-Brazilian Amazonian Climate Observation Study (ABRACOS) (INPE, 1998), localizadas na bacia do Ji-Paraná, uma na reserva Jaru e outra na Fazenda Nossa Senhora (Figura 5), foram utilizados para calcular a relação entre a temperatura máxima e temperatura média diária. A primeira torre está localizada em área coberta por floresta e a segunda por pastagem. Assim, considerando que a imagem composta se refere à temperatura máxima mensal, podemos transformá-la em uma imagem de temperatura média, através da relação linear obtida entre as temperaturas máxima e a média 
determinadas nas torres. Estas imagens de temperatura média mensal foram utilizadas no cálculo da evapotranspiração potencial pelo método de Thornthwaite (1948).

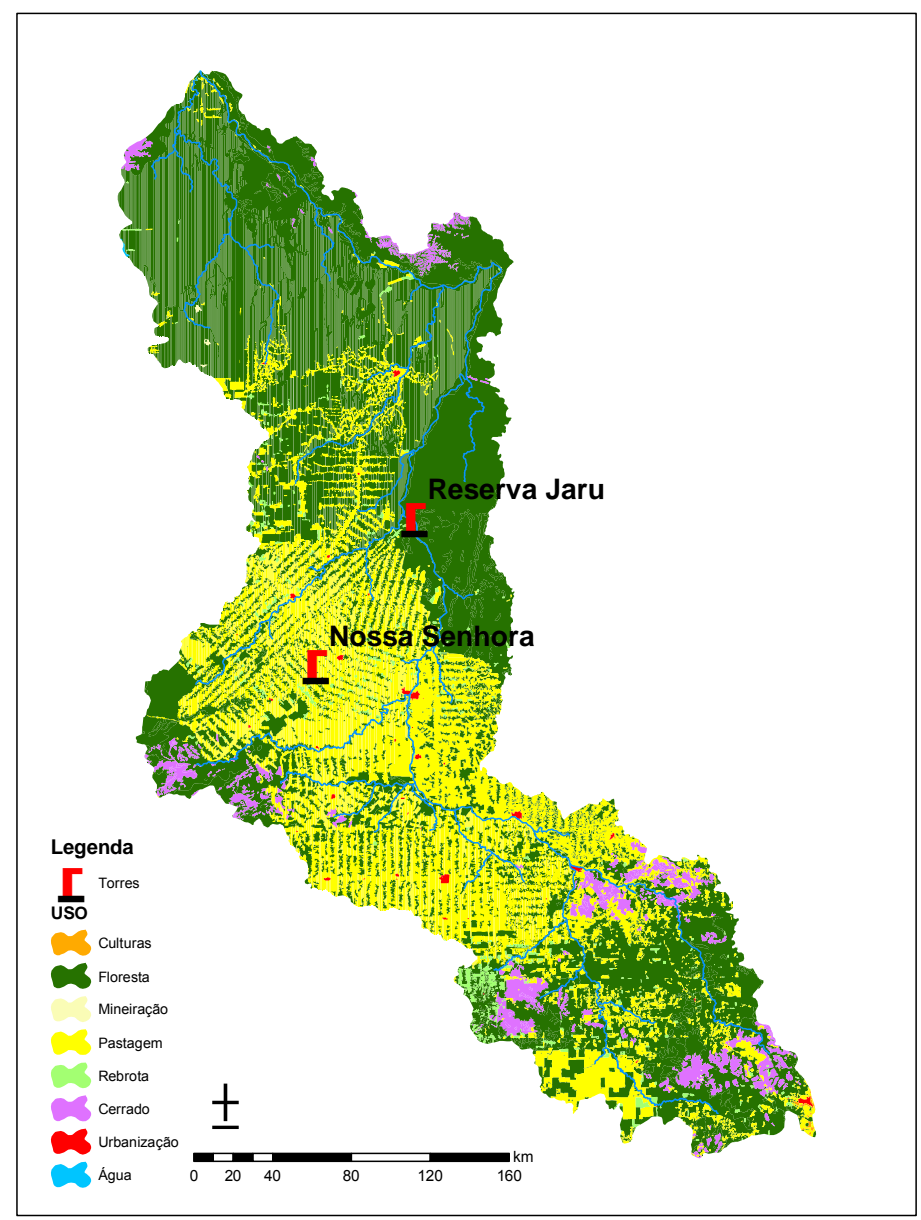

Figura 5 - Localização das torres de medição meteorológica do projeto ABRACOS e uso do solo na bacia do Ji-Paraná em 1996 (INPE, 1998; Hanada, 2004)

Inicialmente, seriam calculadas as relações entre a temperatura máxima e a média para cada mês do período de dois anos e para cada tipo de cobertura (pasto ou floresta). Porém, isso implicaria em 48 fórmulas distintas para a correção da temperatura (24 meses x 2 classes de cobertura). Cada imagem estaria sendo corrigida por duas fórmulas diferentes, cada uma das quais composta por observações de apenas um mês. Isto resultaria em um modelo com poucas observações. Somado a isso, alguns meses do projeto ABRACOS não possuem medidas. Optou-se então por trabalhar com períodos do ano, dividindo o mesmo em estação chuvosa (setembro a fevereiro) e seca (março a 
agosto), mantendo as duas coberturas distintas, floresta e pastagem. Para o cálculo da relação para cada período, foram utilizados dados de 1995 e 1996, com apenas quatro fórmulas necessárias para a correção das imagens. As Figuras 6 e 7 apresentam a relação entre temperatura máxima e média para os períodos seco e chuvoso, respectivamente, para a torre de Jaru (floresta). Observa-se que estas relações foram estaticamente significativas para o nível de $99 \%$ de confiança.

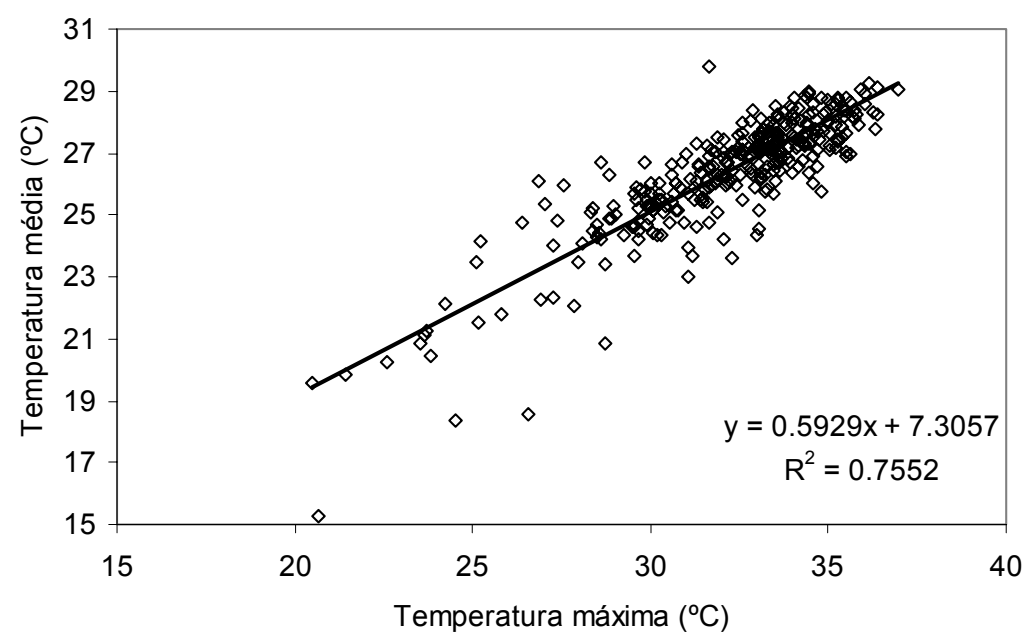

Figura 6 - Relação entre a temperatura máxima e média sobre área de floresta (torre Jaru) para o período seco

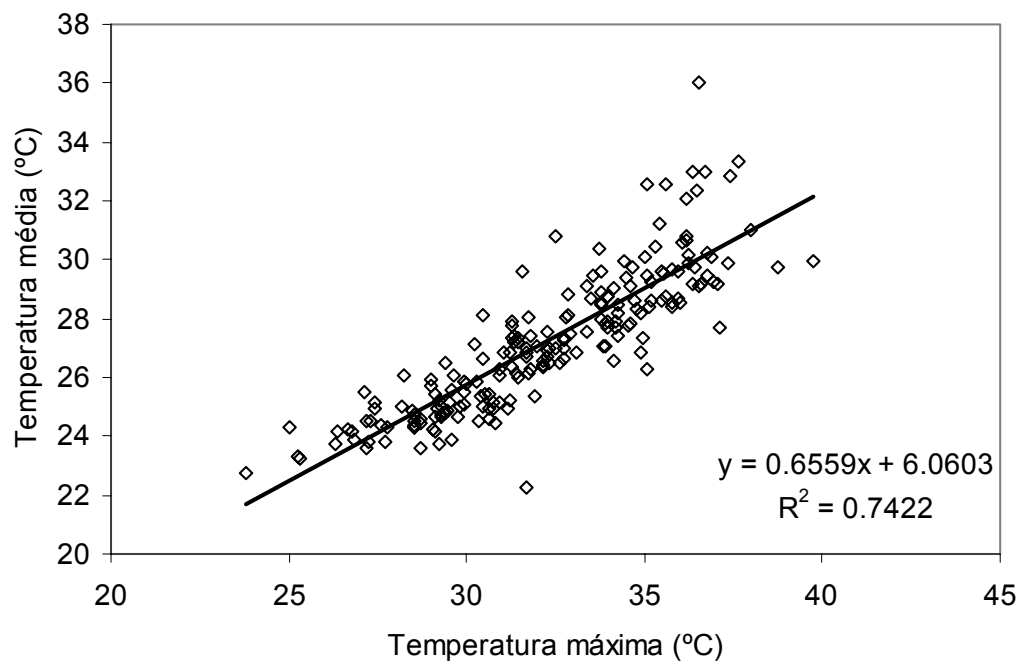

Figura 7 - Relação entre a temperatura máxima e média sobre área de floresta (torre Jaru) para o período chuvoso 
Nas Figuras 8 e 9 estão representadas as mesmas relações, calculadas para a torre de Nossa Senhora (pastagem), nos períodos seco e chuvoso, respectivamente. Estas relações foram estaticamente significativas para o nível de $99 \%$ de confiança.

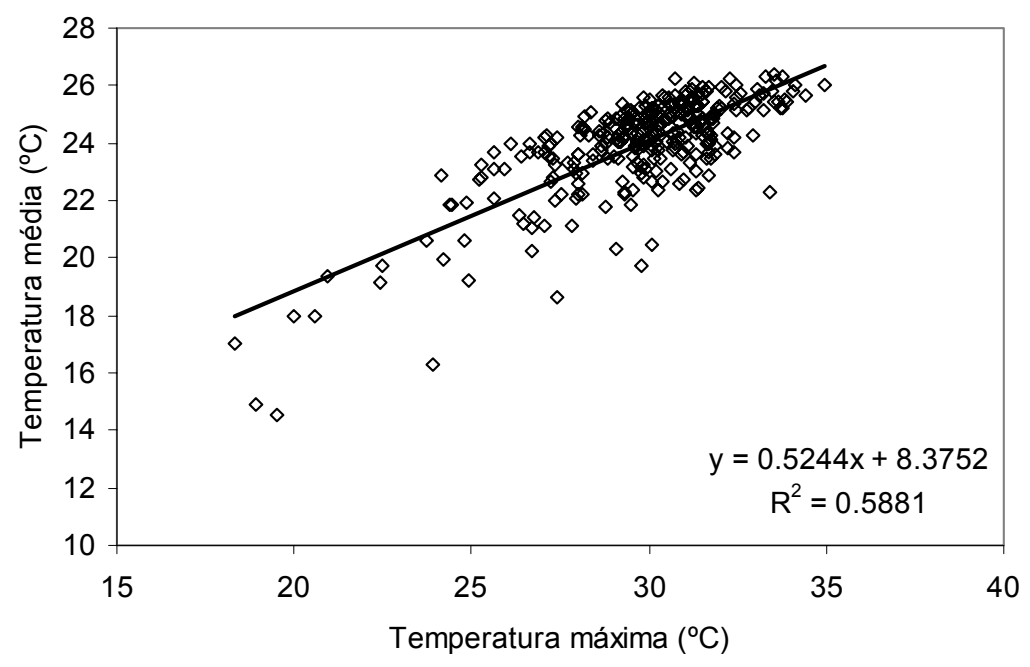

Figura 8 - Relação entre a temperatura máxima e média sobre área de pastagens (torre Nossa Senhora) para o período seco

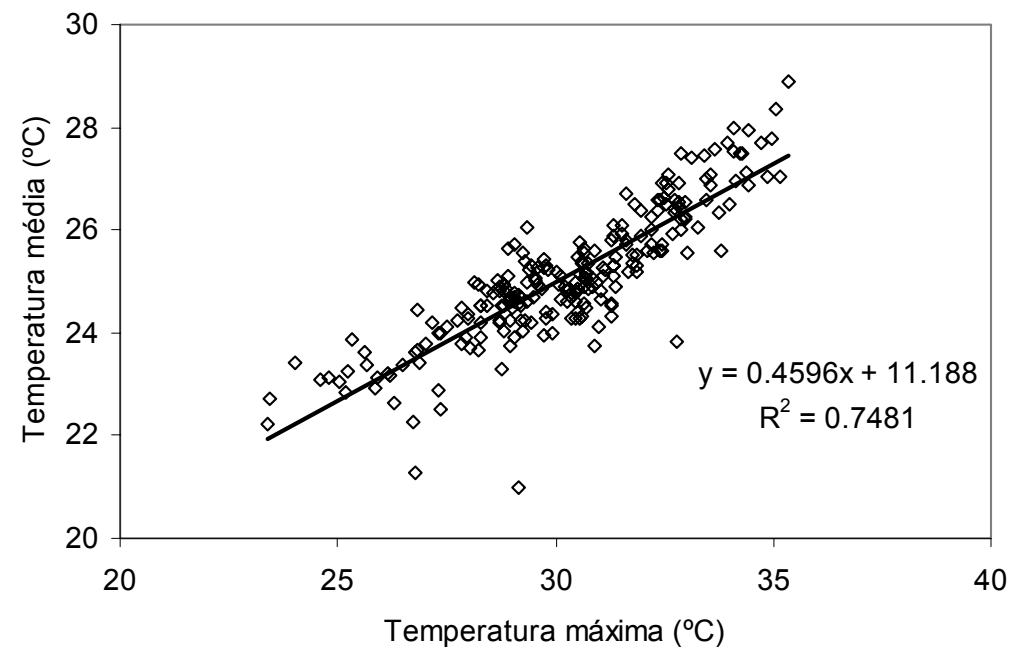

Figura 9 - Relação entre a temperatura máxima e média sobre área de pastagem (torre Nossa Senhora) para o período chuvoso 


\subsubsection{Correção das imagens compostas mensais de temperatura pela temperatura normal}

A correção utilizada no item anterior mostrou-se insuficiente, resultando em imagens mensais onde a temperatura média das imagens se encontrava muito abaixo da temperatura mínima normal da região em alguns meses. A causa mais provável do erro se deve a falta de correção atmosférica. Esta não foi efetuada uma vez que o algoritmo de Ulivieri, ao estimar a temperatura utilizando duas bandas termais adjacentes (banda 4 e 5), elimina os efeitos atmosféricos. No entanto, os efeitos atmosféricos não foram removidos das bandas 1 e 2 , utilizadas na estimativa do IDVN e conseqüente cálculo da emissividade.

Uma vez que as temperaturas para os anos de 1995 e 1996 medidas nas torres meteorológicas do projeto ABRACOS se encontravam próximas aos valores normais da região (Figura 10), uma outra correção foi aplicada às imagens compostas, ao invés da correção que relaciona a máxima mensal com a média. A correção consiste em calcular uma imagem da diferença entre a imagem de temperatura mensal da bacia e a temperatura normal climatológica do mesmo mês. Em seguida, esta diferença é multiplicada por um fator menor que um e adicionada à imagem original. Desta forma, as variações de temperatura da imagem composta mensal são mantidas, e o valor médio da imagem composta de temperatura se aproxima à média histórica daquele mês.

A escolha do fator foi feita de modo a aproximar a temperatura das imagens compostas à temperatura climatológica sem que se perdesse a variabilidade espacial das imagens. Foram testados vários fatores, de 0,1 a 0,9 , sendo que o fator de 0,7 se mostrou adequado. 


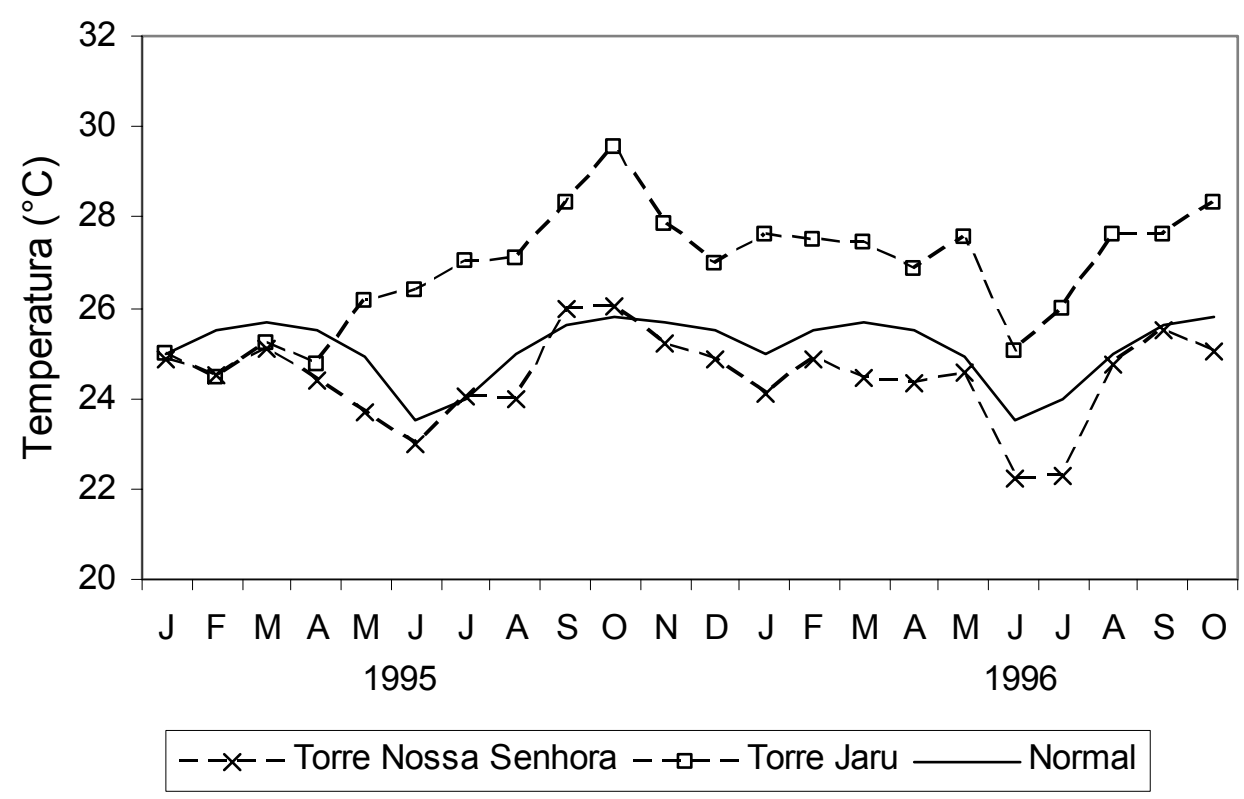

Figura 10 - Temperaturas médias mensais das duas torres meteorológicas do projeto ABRACOS (Jaru sobre floresta e Nossa Senhora sobre pastagem), juntamente com a média normal de Porto Velho, RO (INMET), para os anos de 1995 e 1996

\subsection{Geração das imagens de evapotranspiração potencial}

As imagens de evapotranspiração potencial foram calculadas conforme a metodologia de Thornthwaite (1948), adaptada por Pereira et al.. (2002). Esta utiliza a temperatura mensal média como parâmetro para o cálculo da evapotranspiração potencial padrão para um mês de 30 dias com fotoperíodo de 12 horas (Equação 15). Em seguida, aplica-se uma correção relativa ao o local e período que se pretende calcular a evapotranspiração potencial (Equação 16), conforme as equações 15 a 18 .

$$
\begin{gathered}
E T P p=16 *\left(10 \frac{T m}{I}\right)^{a} \\
E T P=E T P p * \frac{N}{12} * \frac{N D P}{30} \\
I=12 *(0.2 * T a)^{1.514} \\
a=0.49239+1.7912 \cdot 10^{-2} * I-7.71 \cdot 10^{-5} * I^{2}+6.75 \cdot 10^{-7} * I^{3}
\end{gathered}
$$


onde:

ETP $=$ Evapotranspiração potencial mensal $\left(\mathrm{mm}^{*} \mathrm{mês}^{-1}\right)$

$\mathrm{ETPp}=$ Evapotranspiração potencial padrão $\left(\mathrm{mm}^{*} \mathrm{mê}^{-1}\right)$

$\mathrm{N}=$ fotoperíodo do $15^{\circ}$ dia do mês (horas)

NDP $=$ Número de dias do período

$\mathrm{Tm}=$ Temperatura média mensal $\left({ }^{\circ} \mathrm{C}\right)$

$\mathrm{Ta}=$ Temperatura média anual $\left({ }^{\circ} \mathrm{C}\right)$

O fotoperíodo foi calculado a partir da Equação 19 para o $15^{\circ}$ dia de cada mês.

$$
\begin{gathered}
h_{n}=\arccos (-\operatorname{tg} \Phi \cdot \operatorname{tg} \delta) \\
\delta=23,45 \cdot \operatorname{sen}(360 / 365 \cdot(N D A-80))
\end{gathered}
$$

onde:

$\mathrm{h}_{\mathrm{n}}=$ Fotoperíodo (ângulo horário)

$\Phi=$ latitude

$\delta=$ declinação solar

$\mathrm{NDA}=$ Número de dia do ano, ou seja, 01 de Janeiro $=1 ; 01$ de Fevereiro $=32$ etc.

Para temperaturas médias iguais ou superiores a $26,5{ }^{\circ} \mathrm{C}$ utilizou-se a equação proposta por Willmott et al. (1985) no cálculo da evapotranspiração potencial padrão (ETPp), por ser esta mais adequada para temperaturas elevadas (Equação 21).

$$
E T P p=-415.85+32.24 * T m-0.43 * T^{2}
$$

onde:

ETPp $=$ Evapotranspiração potencial padrão $\left(\mathrm{mm}^{*} \mathrm{mê}^{-1}\right)$

$\mathrm{Tm}=$ Temperatura média mensal $\left({ }^{\circ} \mathrm{C}\right)$ 


\subsection{Capacidade de água disponível}

O balanço hídrico a ser aplicado necessita de um parâmetro denominado Capacidade de Água Disponível (CAD). Este parâmetro é definido pela quantidade máxima de água disponível às plantas (Pereira et al., 2002), e sua estimativa é efetuada de acordo com uma tabela de valores médios em função da textura do solo e da profundidade das raízes (Tabela 1).

Tabela 1. Valores médios da Capacidade de água disponível em função da textura do solo

\begin{tabular}{cc}
\hline Textura do solo & $\begin{array}{c}\text { Capacidade de água disponível } \\
\left(\mathrm{mm} \mathrm{H}_{2} \mathrm{O} \mathrm{cm}^{-1} \text { de solo }\right)\end{array}$ \\
\hline Arenosa & 0,5 a 0,75 \\
Média & 0,75 a 1,25 \\
Argilosa & 1,25 a 2,00 \\
\hline
\end{tabular}

FONTE: Pereira et al., 2002

Para a pastagem e demais culturas anuais, a profundidade média das raízes considerada foi de $70 \mathrm{~cm}$. Esta profundidade, aparentemente elevada para pastos, foi escolhida pois muitos dos pastos da região são ditos "sujos", ou seja, com a presença de árvores e arbustos, o que elevaria a profundidade média de raízes. Inicialmente, para as áreas de floresta, considerou-se a profundidade das raízes como $2 \mathrm{~m}$ (Nepstad et al., 1994). Contudo, testes preliminares mostraram que esta profundidade era insuficiente, resultando em uma redução muito drástica da evapotranspiração real na época seca. De acordo com observações de campo na região leste da Amazônia (Nepstad et al., 1994), as raízes das árvores de florestas nativas podem atingir até $8 \mathrm{~m}$ de profundidade. Já na bacia do Ji-Paraná, medidas de evapotranspiração da floresta mostraram que, mesmo após a redução da umidade do solo nos primeiros 3,6 metros de profundidade, a evapotranspiração não foi reduzida (Whright et al., 1996), indicando que as árvores da floresta são capazes de retirar água de profundidades superiores a 3,6 metros. Portanto, 
foi selecionado um valore de 4 metros de profundidade para as raízes de floresta. Áreas urbanas, por totalizar um percentual muito pequeno na bacia (0,24\% em 1996) (Hanada, 2004), foram tratadas como áreas de pasto, simplificando o balanço hídrico como um todo. Áreas de cerrado e rebrota também foram tratadas como pasto, uma vez que, na classificação supervisionada, estas últimas são geralmente pastos abandonados, com predominância de pastagem. Áreas de cerrado, por sua vez, apresentam regime hídrico similar às pastagens, secando nos períodos de estiagem.

\subsubsection{Geração dos mapas de teor de argila e classe textural}

O mapa de teor de argila nos solos da bacia do Ji-Paraná foi gerado a partir da interpolação geoestatística de pontos amostrais, obtidos do banco de dados do Sistema de Informação Geográfica para os Terrenos e Solos do Estado de Rondônia SIGTERON (Cochrane \& Cochrane, 1998). Foram utilizados 756 perfis amostrais (Figura 11), com profundidade média de $30 \mathrm{~cm}$ (horizonte A). Normalmente, tal análise deveria ser efetuada com amostras do horizonte B, por possuir maior expressão pedogênica. Porém, a falta de amostras para este horizonte impossibilitou a interpolação. 


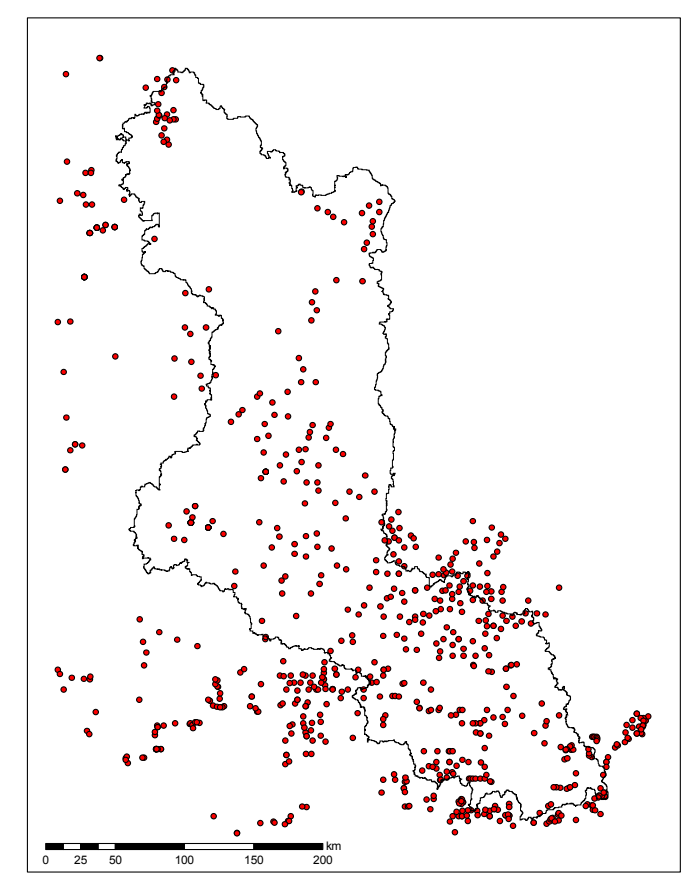

Figura 11 - Localização dos pontos amostrais de textura do solo utilizados na interpolação geoestatística

A análise geoestatística foi efetuada utilizando-se a extensão Geostatistical Analyst do SIG Arc GIS 8.1 (ESRI, 2001), conforme discutido por Victoria et al., 2003. Foi efetuada a krigagem simples com o modelo exponencial. $\mathrm{O}$ alcance do modelo foi de $40 \mathrm{~km}$ com efeito pepita de 67,6 e patamar de 332,7.

O mapa de argila foi dividido nas classes de textura arenosa, média, argilosa e muito argilosa para então ser calculado o valor de $\mathrm{CAD}$, conforme a Tabela 1. A divisão das classes texturais foi feita conforme a Tabela 2 .

Tabela 2. Limites para divisão das classes texturais a partir do teor de argila

\begin{tabular}{cc}
\hline Classe textural & Teor de argila $(\%)$ \\
\hline Arenoso & menor que 15 \\
Médio & 15 a 35 \\
Argiloso & 35 a 60 \\
Muito argiloso & maior que 60 \\
\hline
\end{tabular}
FONTE: EMBRAPA, 1999. 


\subsubsection{Cobertura do solo}

O mapa de cobertura do solo utilizado foi obtido do banco de dados do projeto temático em que este trabalho esta inserido. Este foi gerado a partir da classificação supervisionada das imagens de Landsat 5 que recobrem a bacia no ano de 1996 (Figura 5, página 19) (Hanada, 2004). Para a confecção do mapa de CAD, o número de classes deste mapa foi reduzindo, mantendo-se apenas as classes de pastagem e floresta. Conforme mencionado anteriormente, áreas urbanas e de rebrota foram tratadas como pastagens para simplificar a geração do mapa de CAD.

\subsection{Formulação dos cenários}

Para testar a influência da cobertura do solo no balanço hídrico, três cenários extremos foram utilizados. No primeiro, a bacia é completamente coberta por pastagens, com profundidade radicular de $0,7 \mathrm{~m}$. O segundo, toda a bacia é recoberta por florestas, com a profundidade radicular de $2 \mathrm{~m}$ e o terceiro consiste em aumentar a profundidade radicular do segundo cenário para $5 \mathrm{~m}$ para compreender melhor a influência da profundidade radicular no modelo.

Estes cenários foram implementados apenas alterando-se a profundidade das raízes no mapa de CAD. Portanto, não levam em consideração as mudanças referentes ao balanço de energia que a troca de floresta por pastagem acarretaria, uma vez que, para ambos os cenários, a imagem de temperatura média mensal é a mesma, o que significa que a evapotranspiração potencial entre dois cenários não se altera. 


\section{RESULTADOS E DISCUSSÃO}

\subsection{Mapas de Precipitação}

As Figuras 12 e 13 apresentam as superfícies de precipitação interpoladas para a bacia do Ji-Paraná, para os 23 meses de estudo.

A precipitação média interpolada de toda a bacia durante o período de estudo foi ligeiramente inferior a normal climatológica de Porto Velho (RO), conforme pode ser observado na Figura 14, que compara a precipitação normal acumulada com a precipitação média da bacia acumulada.

A sazonalidade da precipitação interpolada segue o mesmo padrão da normal de Porto Velho (Figura 15). No entanto, a precipitação normal apresenta um aumento no mês de agosto, o qual não ocorre na precipitação interpolada de 1995. Já em 1996, o pico na precipitação ocorre, porém de maneira reduzida. Isso se deve ao fato de Porto Velho estar fora da bacia, mais ao norte do Estado, onde a precipitação é mais elevada, conforme será discutido no item 3.2.

Estes resultados estão de acordo com as precipitações observadas nas estações pluviométricas (Figura 16a, b e c), que apresentam uma quantidade de chuva inferior à normal climatológica, exceto para a estação localizada na sub-bacia Mineração Oriente Novo, a estação mais próxima de Porto Velho, dentro da bacia do Ji-Paraná.

Os meses com as maiores precipitações médias foram fevereiro de 1995 e janeiro de 1996 (349 e 327 mm, respectivamente). As menores precipitações médias ocorreram em agosto de 1995 e julho de 1996 (6 e 3 mm, respectivamente).

A precipitação média sobre a bacia, durante o ano hidrológico (setembro 1995 a agosto 1996), foi de $2043 \mathrm{~mm}$, enquanto que a normal para Porto Velho é de $2354 \mathrm{~mm}$. 

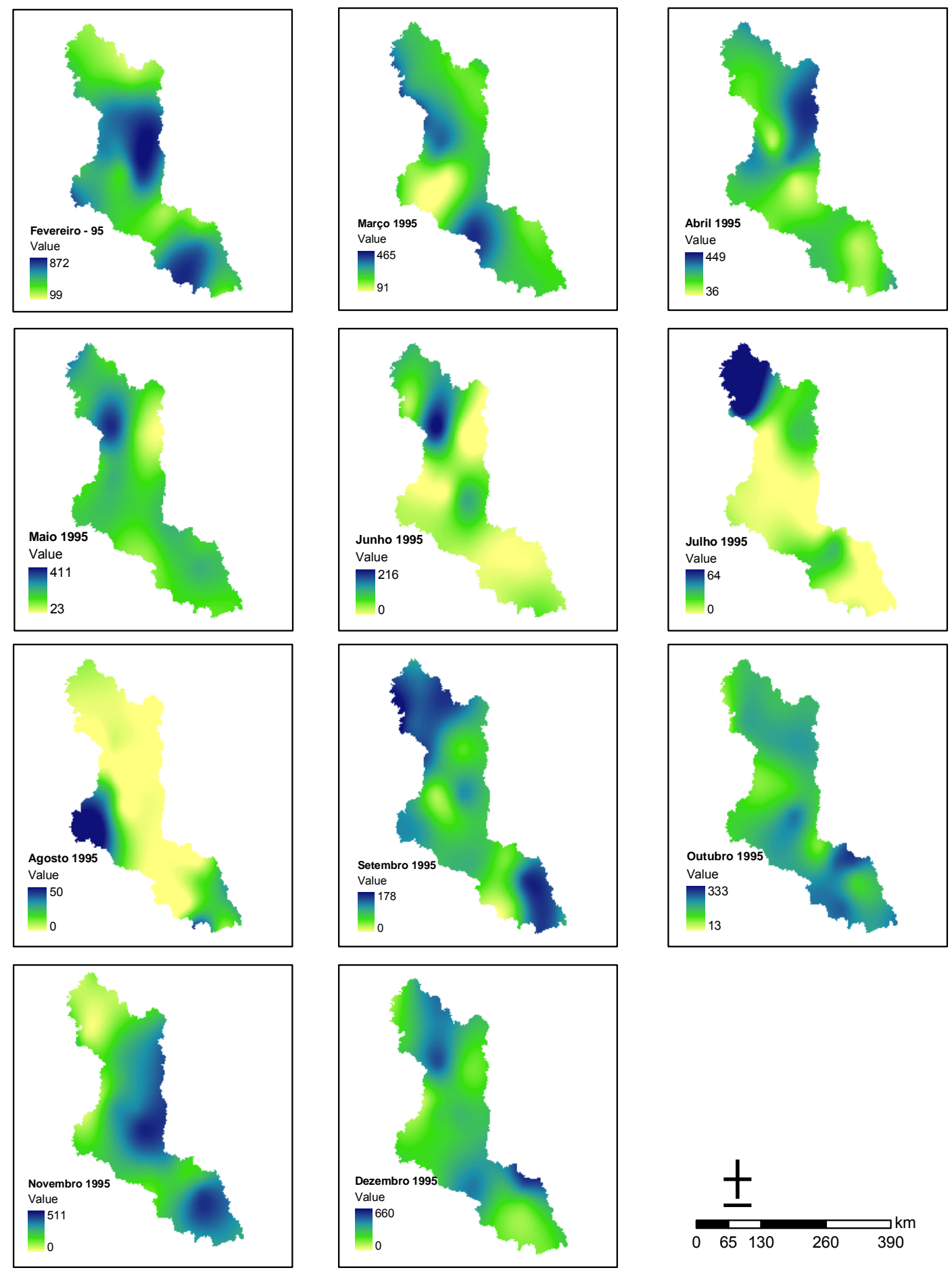

Figura 12 - Imagens mensais de precipitação para o ano de 1995, obtidas pela interpolação das estações pluviométricas da ANA para a bacia do Ji-Paraná 

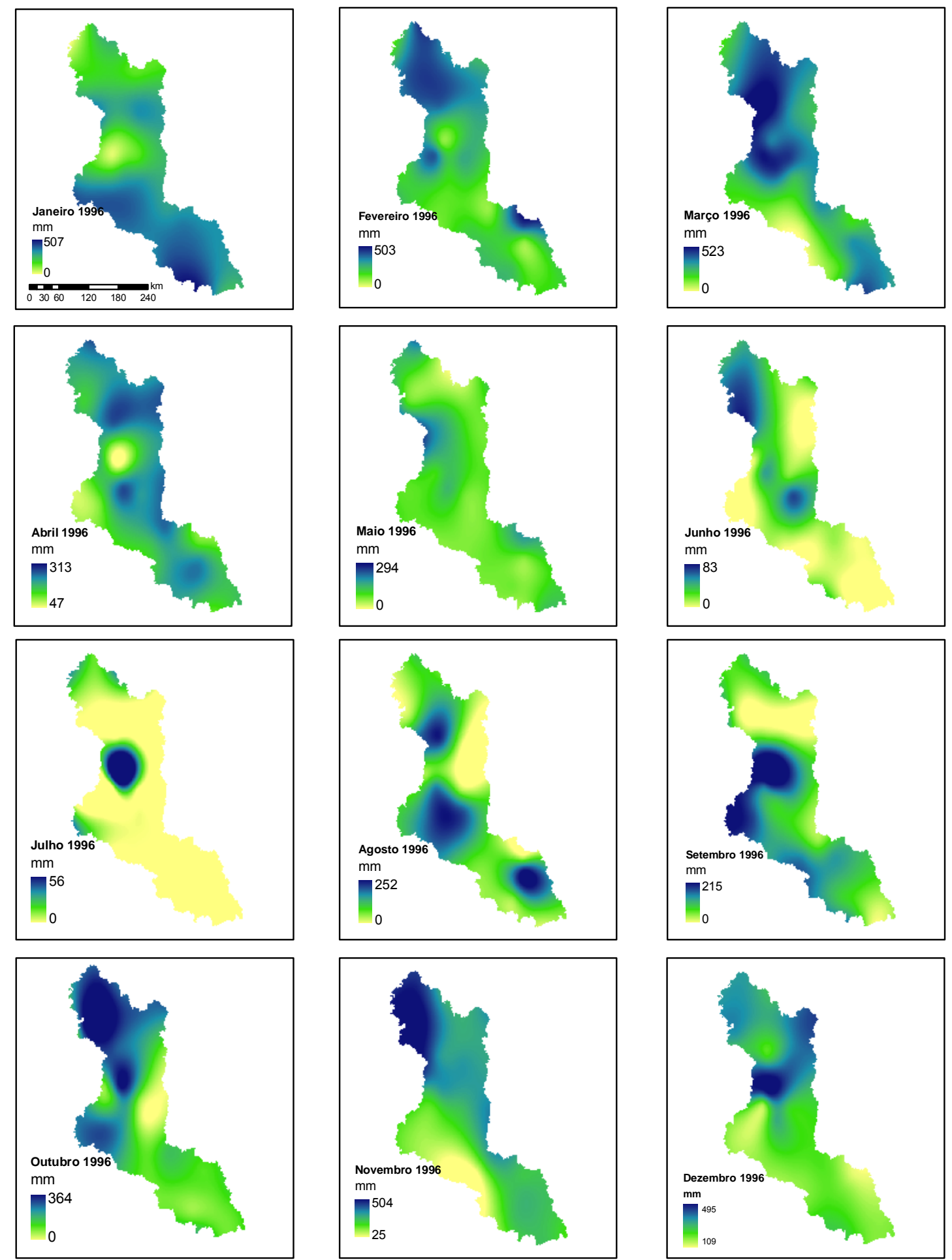

Figura 13 - Imagens mensais de precipitação para o ano de 1996, obtidas pela interpolação das estações pluviométricas da ANA para a bacia do Ji-Paraná 


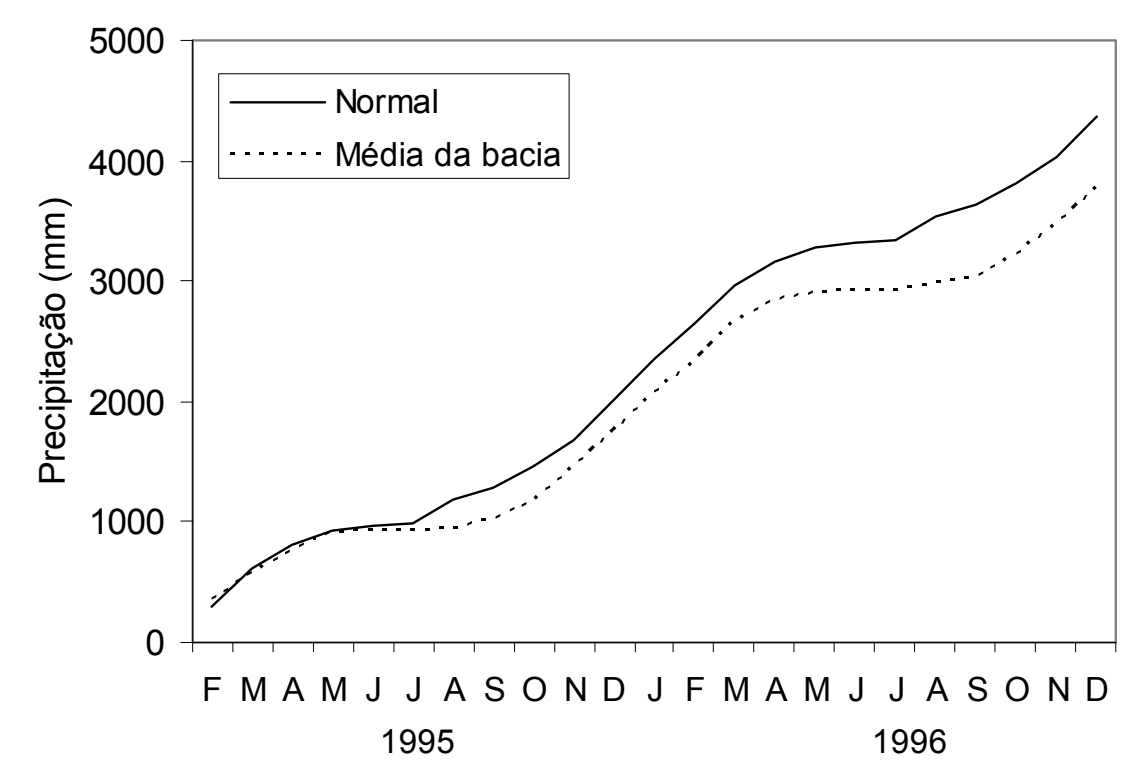

Figura 14 - Comparação entre a precipitação normal acumulada e a média da bacia do Ji-Paraná acumulada, obtida por interpolação utilizando o método spline

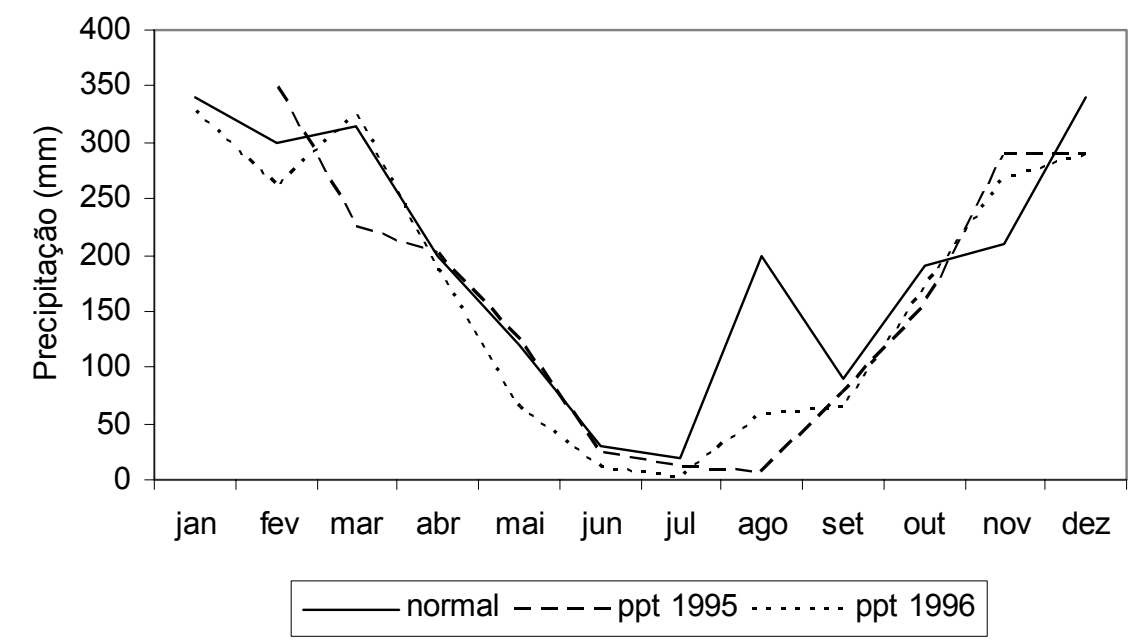

Figura 15 - Precipitação normal de Porto Velho e precipitações médias interpoladas para a bacia do JiParaná para os anos de 1995 e 1996 


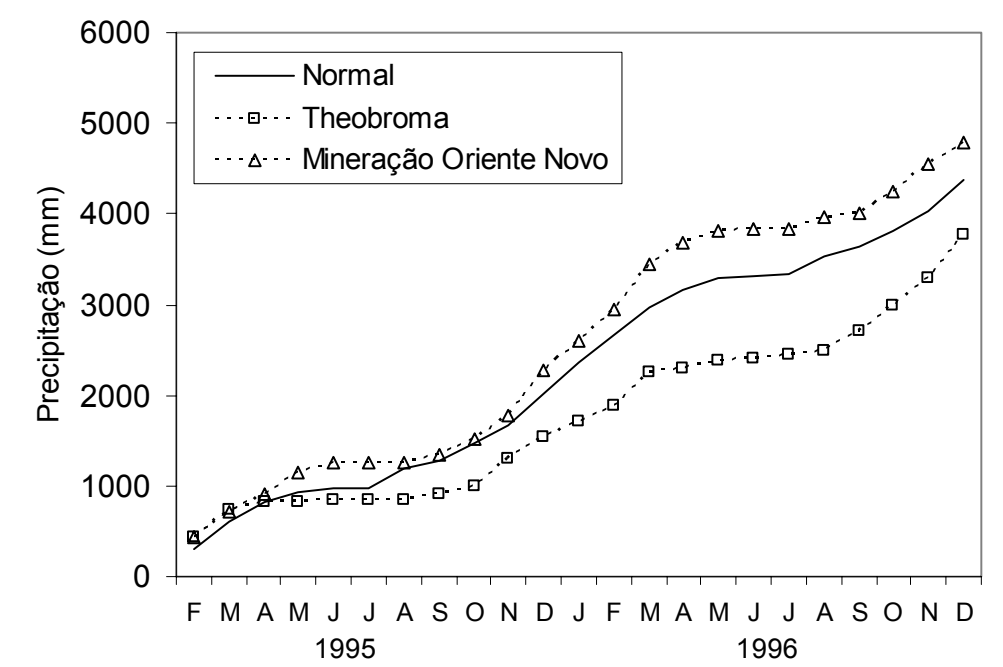

a)

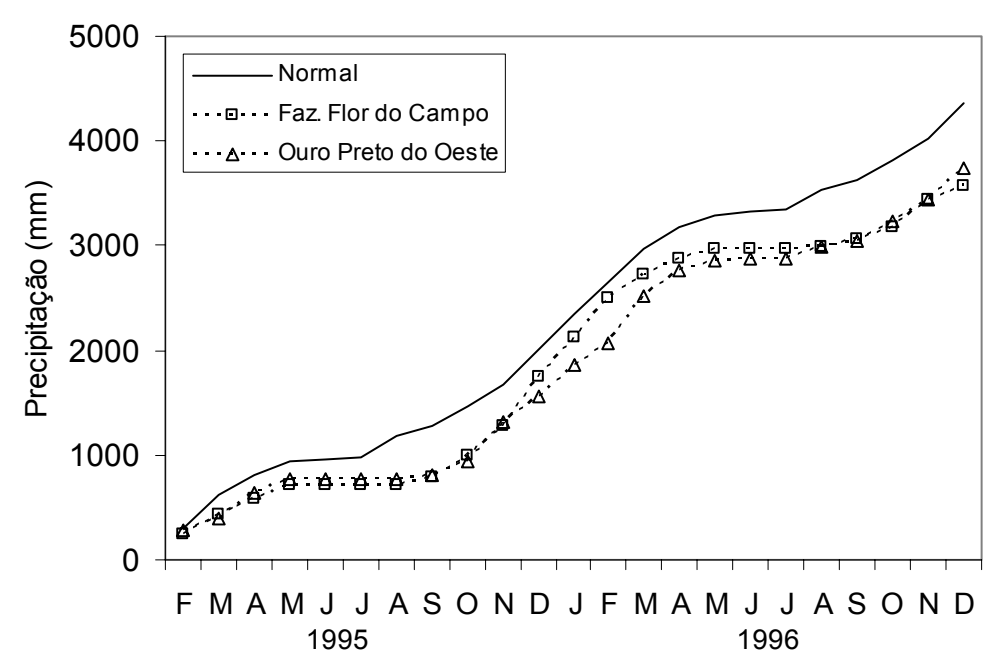

b)

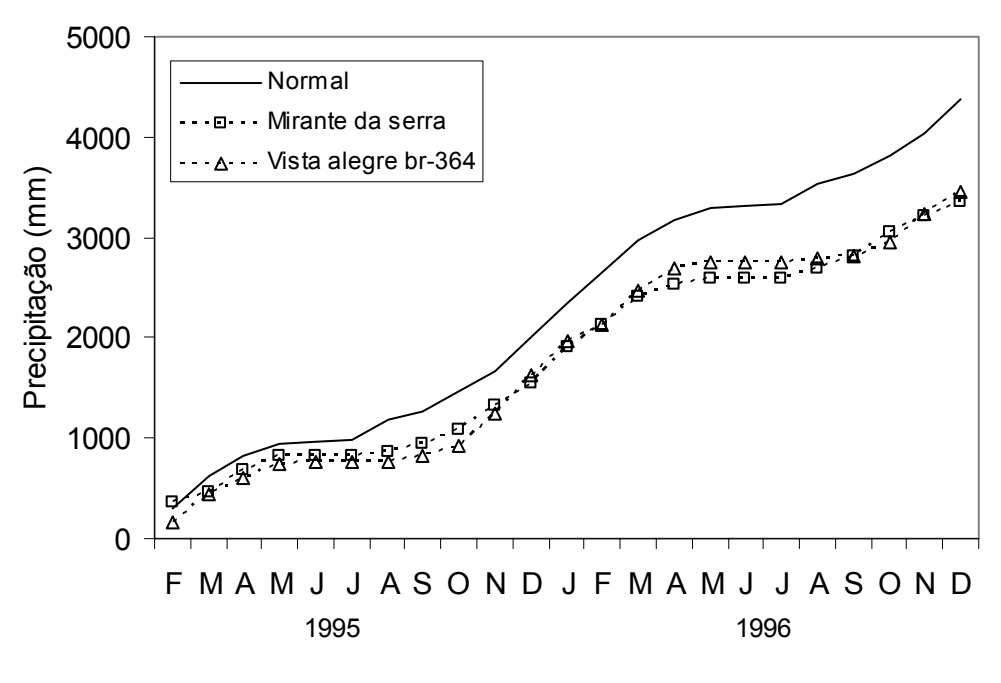

Figura 16 - Comparação entre a precipitação acumuladas das estações a) Theobroma, Mineração Oriente Novo, b) Fazenda Flor do Campo, Ouro Preto do Oeste, c) Mirante da Serra e Vista Alegre Br-364 com a normal de Porto Velho (RO) 
Inicialmente, as superfícies de precipitação foram interpoladas utilizado a metodologia do inverso da distância ao quadrado (IDW). Este método possui a vantagem de ser muito simples e rápido, porém resulta em artifícios de interpolação conhecidos como Bull's Eye, que são feições circulares que ocorrem nos locais onde se encontram os pontos observacionais. Conforme esperado, as superfícies interpoladas pelos dois métodos distintos (IDW e spline) apresentaram diferenças espaciais, principalmente devido às feições circulares geradas (Figura 17).

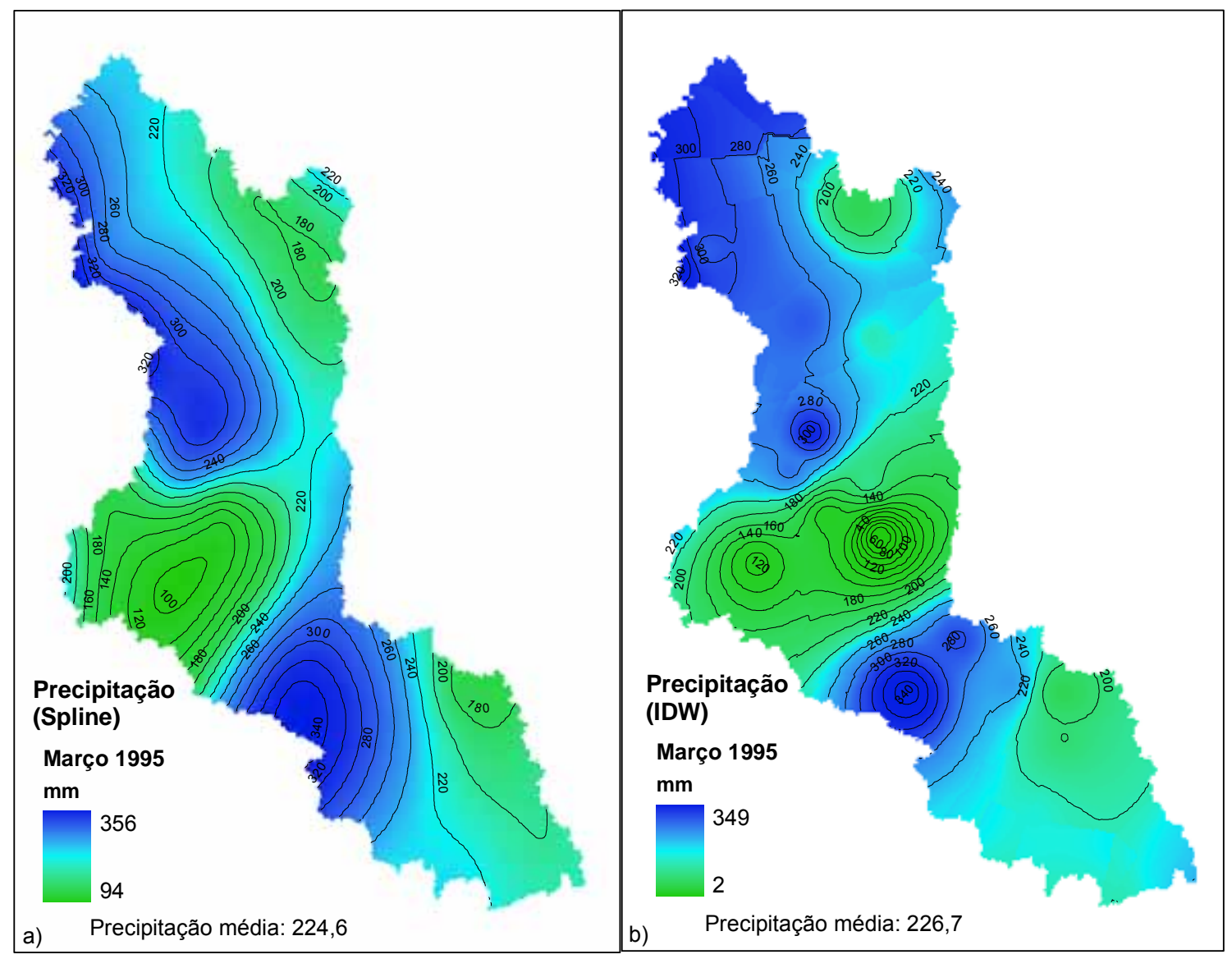

Figura 17 - Precipitação mensal de Março de 1995, interpolada pelo método spline (a) e pelo IDW (b). Intervalo das linhas de contorno é de $20 \mathrm{~mm}$

No entanto, apesar das superfícies interpoladas apresentarem diferenças na distribuição espacial, quantitativamente, a precipitação mensal obtida pelos dois métodos não são distintas, sendo que as precipitações médias mensais ao longo do ano 
praticamente não mudam (Figura 18). As maiores diferenças são encontradas apenas nos valores extremos da precipitação mensal (mínimo e máximo da superfície).

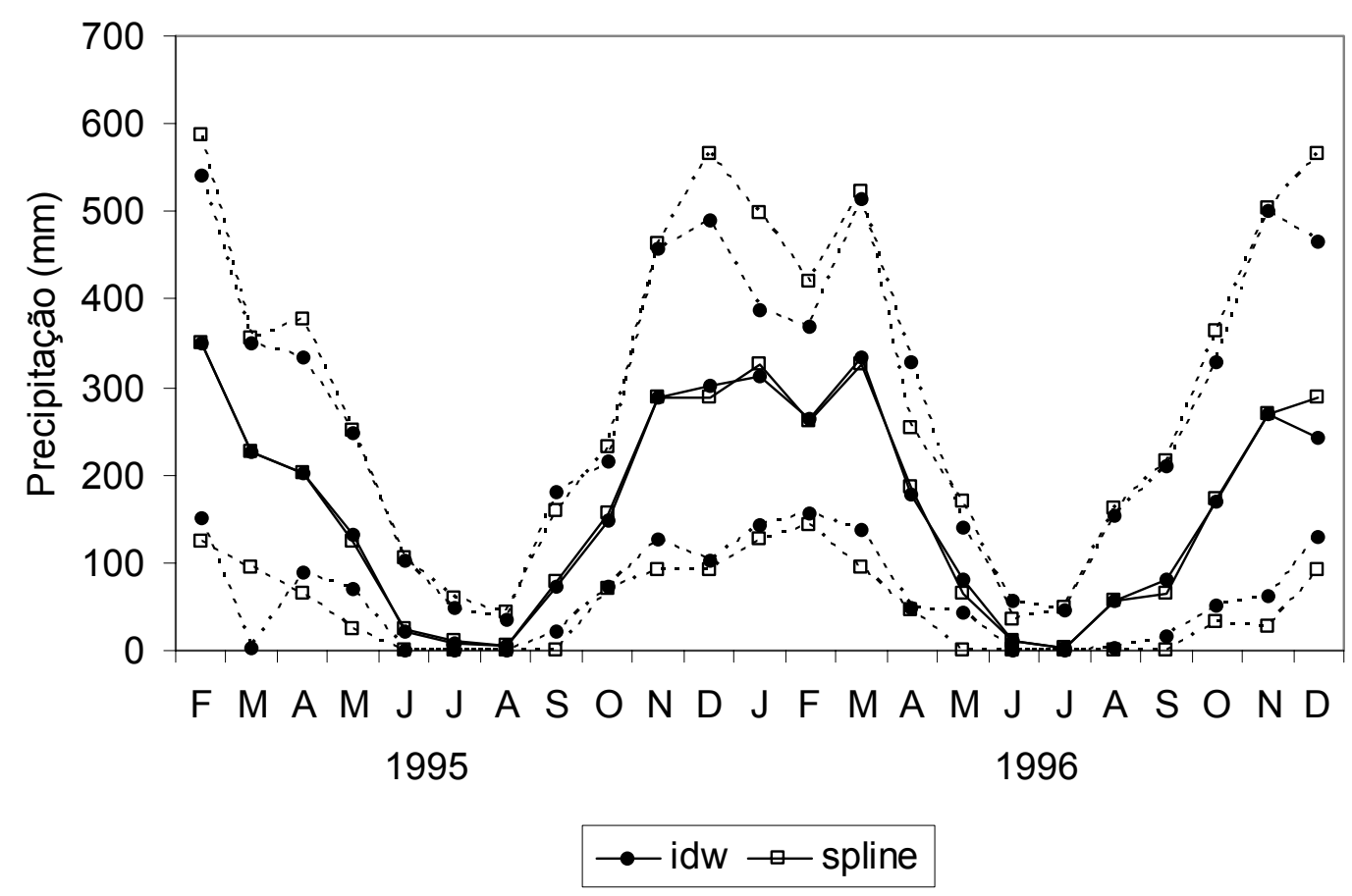

Figura 18 - Precipitação mínima, média e máxima das superfícies de precipitação mensal interpoladas por duas metodologias diferentes, inverso da distância ao quadrado (idw) e spline

\subsection{Balanço de massa nas sub-bacias}

A evapotranspiração anual média calculada pelo balanço de massa para as 10 sub-bacias definidas pelas estações fluviais é de $1274 \mathrm{~mm}$. Este valor difere em menos de 20 \% daqueles estimados para a bacia Amazônica por diversos autores, i.e. $1168 \mathrm{~mm}$ ano $^{-1}$ (Villa Nova et al., 1976), $1508 \mathrm{~mm}^{-1}$ ano $^{-1}$ (Ribeiro \& Villa Nova, 1979) e $1493 \mathrm{~mm}$ ano $^{-1}$ (Leopoldo et al., 1995). Considerando-se que esses valores são para a região central da Amazônia, onde a umidade é maior, e que Rondônia apresenta uma época seca distinta, conclui-se que o balanço de massa realizado deste trabalho é coerente com as informações que se têm da região. 
A área de cada sub-bacia, a porcentagem de pasto, a precipitação, descarga e a evapotranspiração real obtida pelo balanço de massa são apresentados na Tabela 3. Os resultados são referentes ao período de setembro de 1995 a agosto de 1996, período considerado como ano hidrológico da região.

Tabela 3. Área, porcentagem de cobertura de pasto, precipitação, vazão e evapotranspiração (ET) para cada sub-bacia da bacia do Ji-Paraná. Evapotranspiração calculada pela diferença entre precipitação e descarga. Dados referentes ao ano hidrológico de setembro de 1995 a agosto de 1996

\begin{tabular}{|c|c|c|c|c|c|c|}
\hline Sub-Bacia & $\begin{array}{l}\text { Área } \\
\left(\mathrm{km}^{2}\right)\end{array}$ & $\begin{array}{l}\text { Pasto } \\
(\%)\end{array}$ & $\begin{array}{l}\text { Precipitação } \\
\left(\mathrm{mm} \text { ano }^{-1}\right)\end{array}$ & $\begin{array}{c}\text { Vazão } \\
\left(\mathrm{mm}^{-1} \text { ano }^{-1}\right)\end{array}$ & $\begin{array}{c}\text { ET } \\
\left(\mathrm{mm}^{-1} \text { ano }^{-1}\right)\end{array}$ & $\begin{array}{c}\mathrm{ET} \\
\left(\mathrm{mm} \mathrm{dia}^{-1}\right)\end{array}$ \\
\hline $\begin{array}{l}\text { Mineração } \\
\text { Jacunda }\end{array}$ & 1130,47 & 9,41 & 2180 & 719 & 1461 & 4,00 \\
\hline Faz. Expansão & 3575,51 & 55,00 & 1998 & 678 & 1320 & 3,62 \\
\hline Jaru & 3952,05 & 61,40 & 1768 & 815 & 953 & 2,61 \\
\hline $\begin{array}{l}\text { Faz. Flor do } \\
\text { Campo }\end{array}$ & 4298,87 & 35,80 & 2187 & 810 & 1377 & 3,77 \\
\hline Piratininga & 4378,67 & 30,30 & 2280 & 867 & 1412 & 3,87 \\
\hline Comemoração & 5800,90 & 42,50 & 2201 & 844 & 1356 & 3,72 \\
\hline $\begin{array}{l}\text { Cachoeira } \\
\text { Primavera }\end{array}$ & 9598,84 & 49,40 & 1975 & 791 & 1183 & 3,24 \\
\hline Pimenta Bueno & 10079,92 & 50,50 & 1978 & 745 & 1232 & 3,38 \\
\hline Ji-Paraná & 32893,50 & 56,90 & 2018 & 796 & 1221 & 3,35 \\
\hline Tabajara & 60205,40 & 48,00 & 2024 & 806 & 1217 & 3,34 \\
\hline Média & & & 2061 & 787 & 1273 & 3,49 \\
\hline
\end{tabular}

A evapotranspiração real média diária das sub-bacias variou de 2,6 a $4 \mathrm{~mm} \mathrm{dia}{ }^{-1}$, sendo que a menor evapotranspiração ocorreu na sub-bacia Jaru, que tem o maior porcentagem de desmatamento. A sub-bacia Mineração Jacunda, com a menor porcentagem de pastagens, teve a maior evapotranspiração real. Estes resultados indicam que o desmatamento pode estar associado com a redução da evapotranspiração. Diversos estudos indicam que o desmatamento pode reduzir a evapotranspiração e aumentar a descarga da bacia (Bosh \& Hewlett, 1982; Bruijnzeel, 1996; Costa et al., 2003). 
Comparações diretas entre a evapotranspiração e a descarga das diferentes sub-bacias com seu grau de desmatamento não são válidas pois existem diferenças na precipitação das mesmas. A razão descarga/precipitação permite comparar melhor as diferentes subbacias, pois o efeito da precipitação é removido. Sub-bacias mais desmatadas apresentaram maior relação descarga/precipitação indicando que o desmatamento resulta em aumento na porcentagem da precipitação que deixa a bacia na forma de descarga (Figura 19). A relação ET/precipitação apresenta relação contrária (Figura 20), pois esta é complementar a relação descarga/precipitação, ou seja, a precipitação é a soma da descarga e da evapotranspiração ao final de um ano hidrológico.

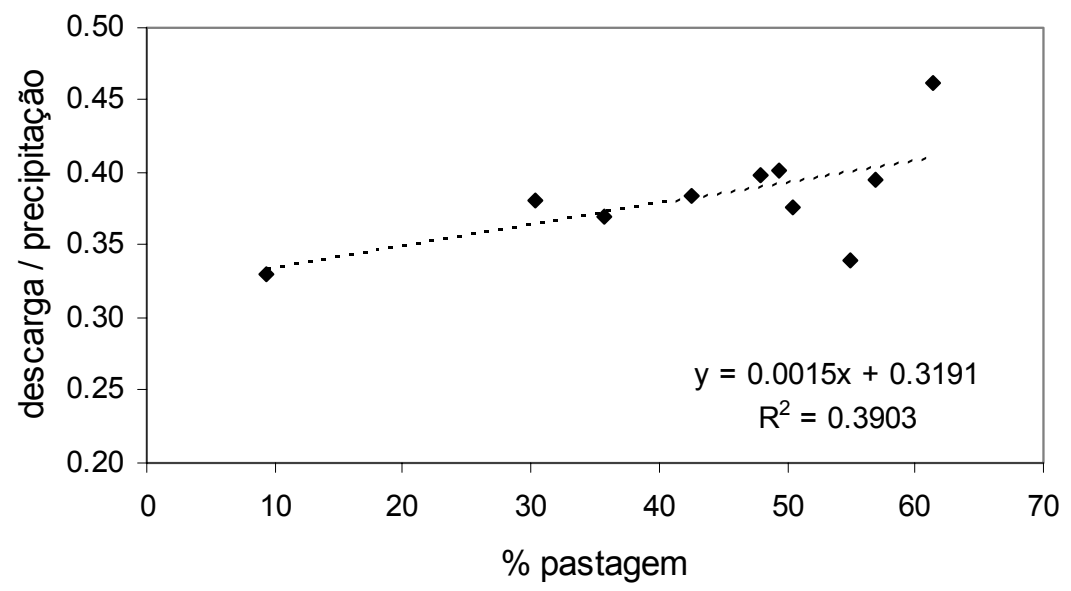

Figura 19 - Razão descarga/precipitação em relação ao desmatamento de cada sub-bacia. Regressão significativa a $95 \%$

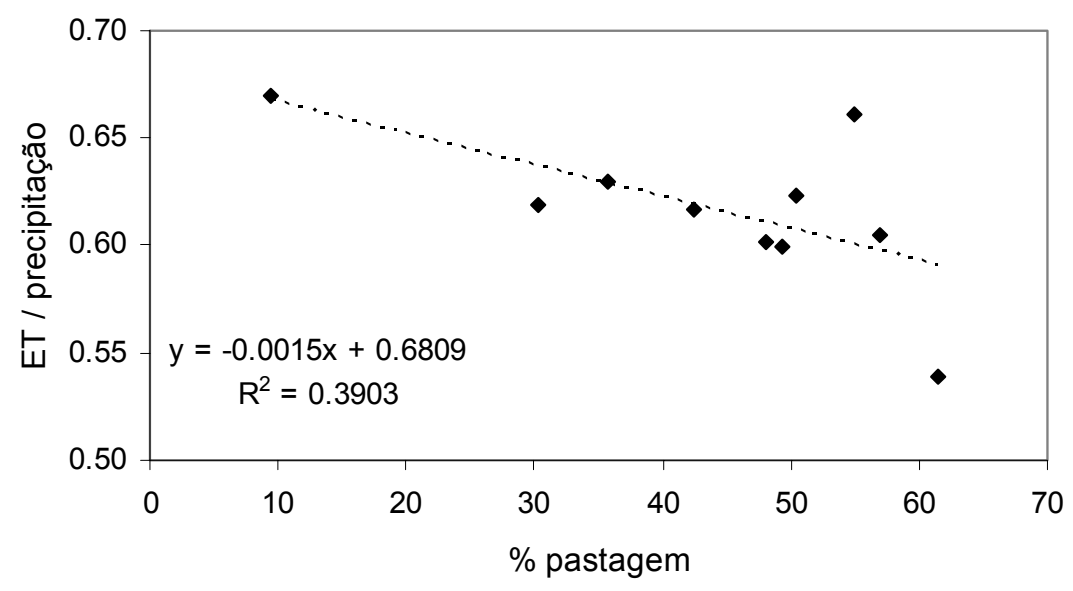

Figura 20 - Razão ET/precipitação em relação ao desmatamento de cada sub-bacia. Regressão significativa a $95 \%$ 
$\mathrm{O}$ balanço de massa das 10 sub-bacias confirma que o desmatamento altera o ciclo hidrológico, aumentando a descarga em relação à precipitação e reduzindo a evapotranspiração. Estas conclusões são baseadas em dados medidos de precipitação e descarga, mostrando o efeito do desmatamento no ciclo hidrológico sem o uso de modelos.

Verificou-se também que as sub-bacias mais desmatadas apresentam menor precipitação (Figura 21). Apesar de estudos a partir de modelos climáticos indicarem redução da precipitação com o desmatamento de grande escala da Amazônia (Shukla et al., 1990; Werth \& Avissar, 2002), este não é o caso das sub-bacias estudadas. O desmatamento do Ji-Paraná não pode ser considerado como sendo de grande escala, como é o caso da remoção completa da Amazônia. Além disso, o desmatamento do JiParaná é mais intenso na parte sul, região naturalmente com menor precipitação (Figura 22). Portanto, a menor precipitação observada nas sub-bacias mais desmatadas do JiParaná esta mais relacionada à localização da sub-bacia e não ao seu grau de desmatamento.

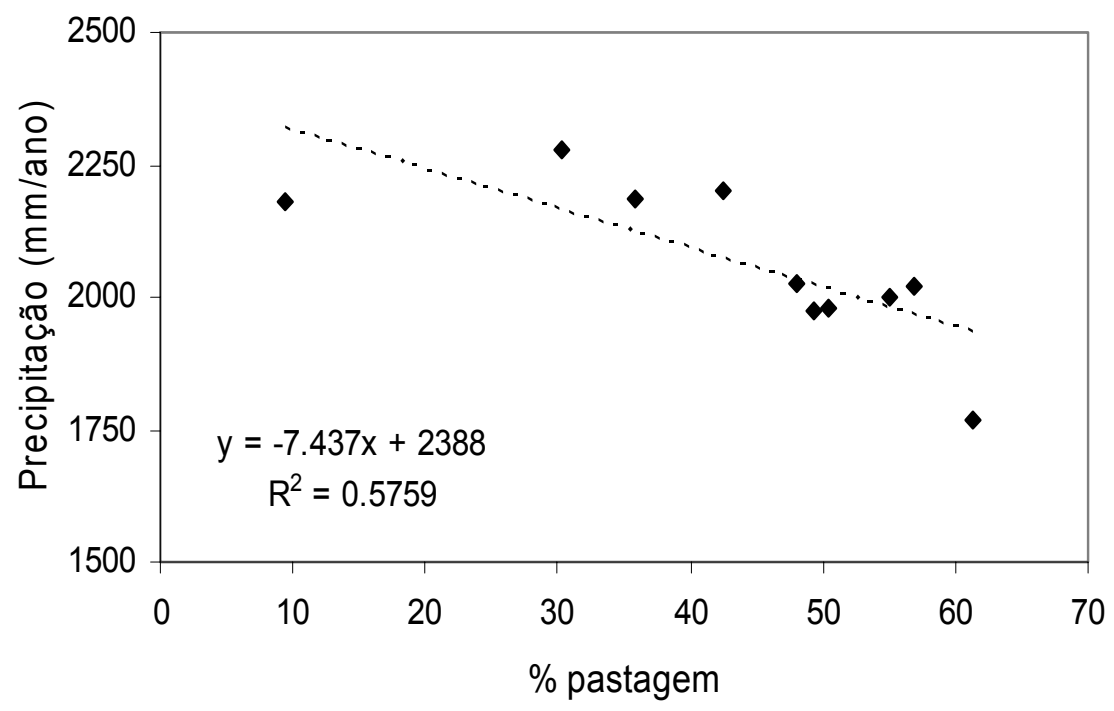

Figura 21 - Precipitação das 10 sub-bacias em relação a porcentagem de cobertura de pasto de cada uma 


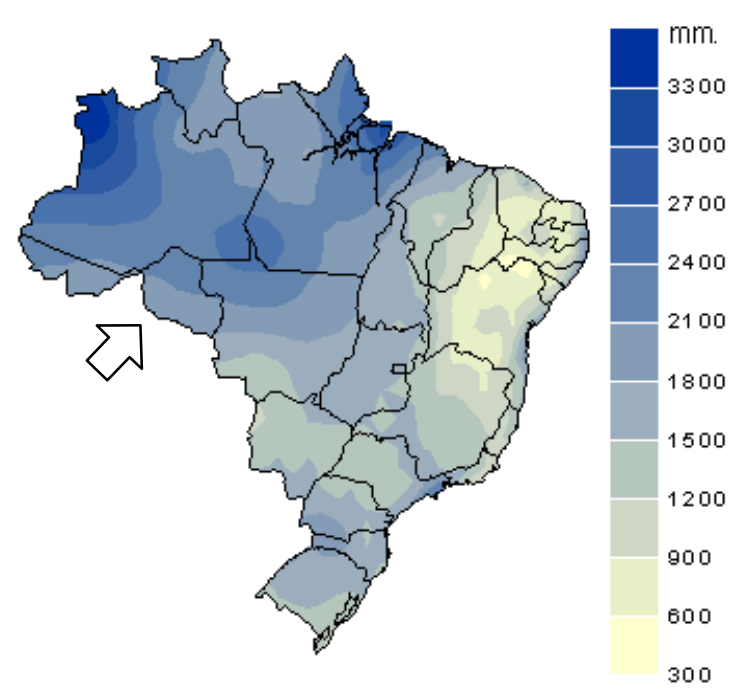

Figura 22 - Precipitação anual normal (média 1931 - 1990) no Brasil. Note a menor precipitação ao sul de Rondônia (Fonte: INMET)

\subsection{Imagens compostas de temperatura}

\subsubsection{Remoção de nuvens e média mensal das imagens diárias}

A análise visual das imagens antes e depois de passar pelo programa de deteç̧ão automática de nuvens mostrou que o algoritmo teve um desempenho muito bom, detectando as nuvens de maneira rápida e consistente, funcionando do mesmo modo para imagens de diferentes épocas do ano. Além de detectar nuvens, o algoritmo também se mostrou eficiente para a remoção de algumas áreas sob a influência de efeitos atmosféricos como o espalhamento causado por partículas de fumaça, freqüentes em Rondônia na época da seca devido às queimadas. As Figura 23e 24 apresentam um exemplo destes resultados. Na primeira, as núvens são representadas em tons amarelo, laranja e verde enquanto que na segunda, estas foram identificadas, sendo representadas pela máscara cor de rosa. 


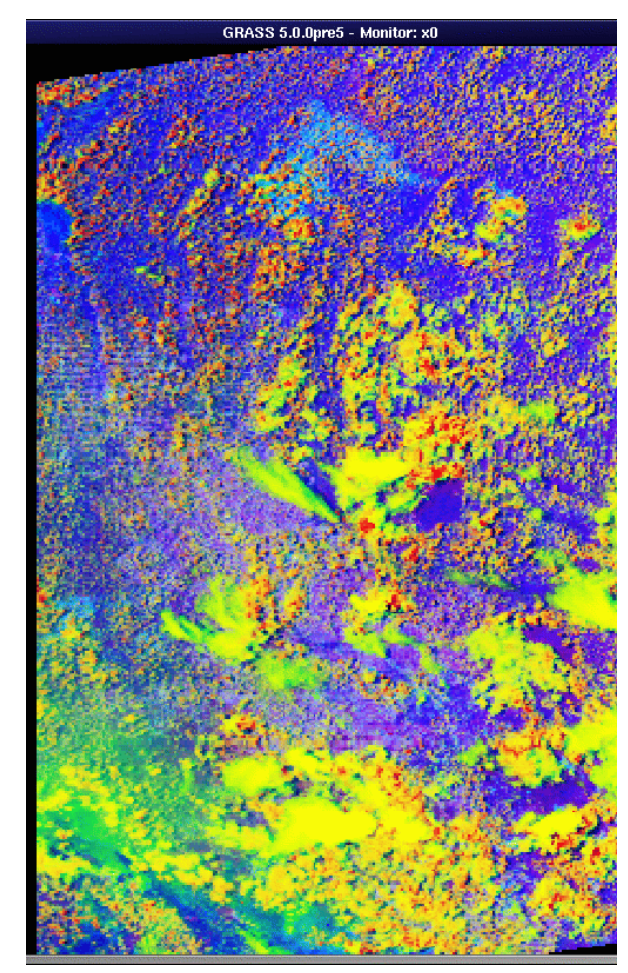

Figura 23 - Falsa composta colorida de imagem AVHRR sobre a bacia do Ji-paraná, março de 1995 (bandas 2, 4 e 3-4)

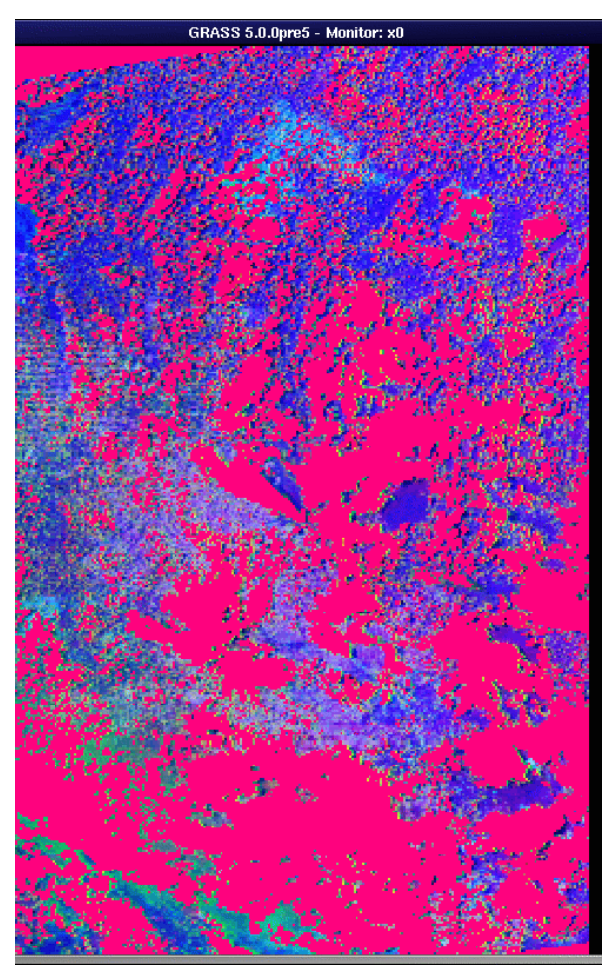

Figura 24 - Falsa composta colorida sobreposta por máscara gerada pelo algoritmo de detecção automática de nuvens

\subsubsection{Correção dos valores extremos e preenchimento de falhas}

As compostas mensais apresentavam algumas regiões sem dados de temperatura, por serem locais que em todas as imagens diárias utilizadas estavam cobertas por nuvens, ou pixeis com valores muito extremos, incompatíveis com a região, com valores irreais como $-37,6{ }^{\circ} \mathrm{C}$ ou $127,7^{\circ} \mathrm{C}$. Estes valores resultaram de pixeis com influência de nuvens ou fumaça de queimadas que não foram detectadas pelo algoritmo por serem menores que a resolução espacial, pixeis compostos por uma média de poucos valores ou píxeis com problemas devido ao mau funcionamento do sensor num determinado dia.

A correção aplicada alterou apenas os valores extremos das imagens compostas, mantendo a média, mediana e quartis quase inalterados. Como ilustração, são apresentados os valores da composta mensal de fevereiro de 1995, antes e após a correção (Tabela 4), além do gráfico de densidade da mesma (Figura 25). 
Tabela 4. Valores médio, mediano, quartis e extremos da imagem composta mensal de temperatura de fevereiro de 1995 da bacia do Ji-Paraná, antes e depois da aplicação do filtro. (em Celsius)

\begin{tabular}{ccccccc}
\hline Imagem & Mínima & $1^{\circ}$ Quartil & Mediana & Média & $3^{\circ}$ Quartil & Máxima \\
\hline Sem correção & $-37,6$ & 18,5 & 22,2 & 21,8 & 25,8 & 127,7 \\
Após correção & 10 & 18,6 & 22 & 21,9 & 25,2 & 32 \\
\hline
\end{tabular}

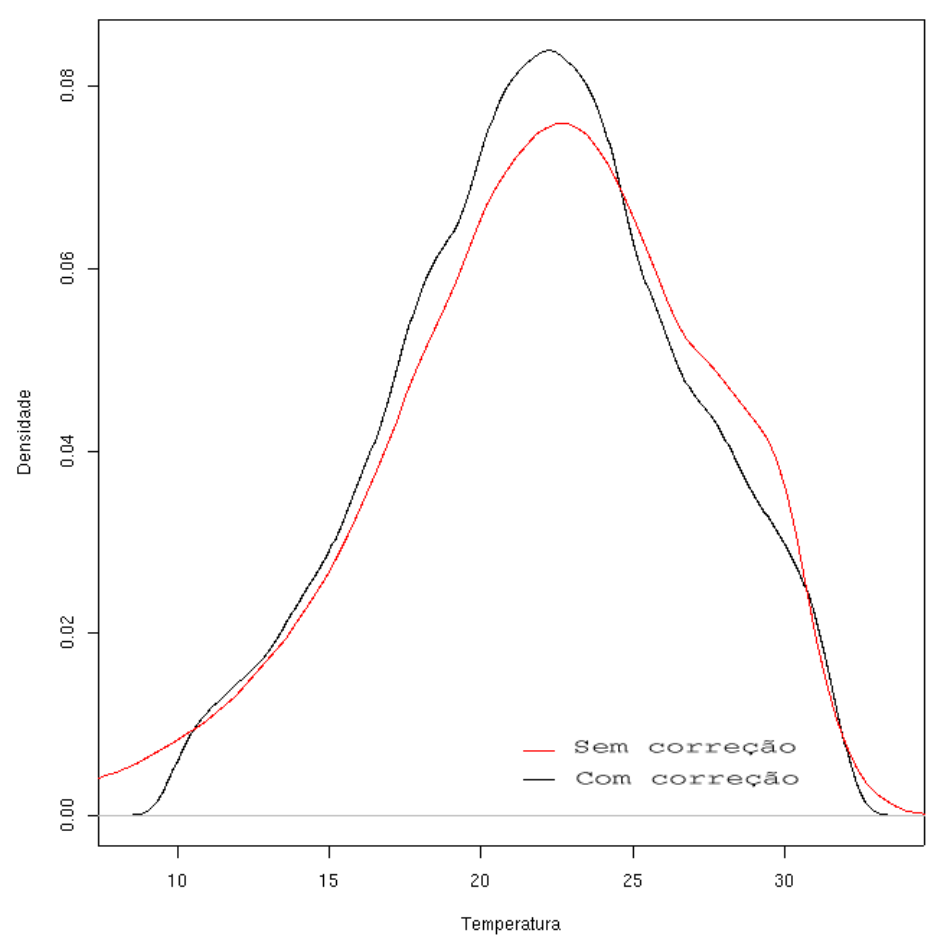

Figura 25 - Curva de densidade das compostas mensais de temperatura para fevereiro de 1995, antes (vermelha) e após (preta) aplicação do filtro e corte da bacia. Note-se que antes da aplicação do filtro, a curva de densidade se estende para fora do gráfico

Observa-se na Figura 25 pequenas diferenças na curva de densidade, pois além do filtro para correção dos valores extremos, as imagens compostas mensais também são cortadas no formato da bacia, removendo as células que estão nas bordas da imagem composta, o que altera ligeiramente o formato da curva de densidade.

Mesmo após a aplicação deste procedimento de correção dos valores extremos, algumas imagens apresentavam píxeis com valores fora da faixa determinada. Porém, analisando essas imagens individualmente, observou-se que estes valores extremos estavam bem próximos aos limites definidos pela média da imagem, mais ou menos 
duas vezes o desvio padrão. Além disso, estes valores ocorrem em píxeis isolados pela imagem, muitos deles fora da bacia de estudo. Isso demonstra que o método empregado foi eficaz na remoção de grandes áreas com valores discrepantes, restando apenas alguns poucos pontos isolados fora do intervalo determinado, com valores muito próximos aos limites.

Algumas imagens compostas mensais apresentavam temperaturas muito baixas ou altas para a região, mesmo após a remoção dos valores extremos (Tabela 5). Temperaturas muito elevadas, geralmente ocorrem em células onde a temperatura mensal é calculada com apenas um ou dois dias de observação do satélite. Tal padrão foi observado em células da imagem de Julho de 1995, que apresenta temperatura máxima de $41^{\circ} \mathrm{C}$. Já temperaturas muito baixas, como por exemplo, $10^{\circ} \mathrm{C}$ em fevereiro de 1995 ou $11^{\circ} \mathrm{C}$ em novembro de 1996 , podem ser resultantes de dois erros. O primeiro é a contaminação por nuvens menores que a resolução espacial da imagem $(1$ x $1 \mathrm{~km})$, não detectadas pelo algoritmo utilizado e que reduzem a temperatura do pixel. O segundo, e mais influente, está relacionado ao cálculo da emissividade, utilizada no cálculo da temperatura da superfície.

Pozo Vázquez et al. (1997) identificaram dois grandes problemas na estimativa da temperatura utilizando satélites: efeitos atmosféricos e estimativa da emissividade da superfície. O primeiro problema é sanado uma vez que o algoritmo para o cálculo da temperatura de Ulivieri et al. (1994) utiliza duas bandas espectrais adjacentes, as bandas 4 e 5 do sensor AVHRR, para a correção do efeito da atmosfera, um método conhecido como "split window". Quanto à emissividade, esta foi determinada através da relação com o IDVN, de acordo com Van de Griend \& Owe ${ }^{1}$. Segundo os autores, a diferença entre as temperaturas medidas in loco e estimadas por satélite, utilizando o IDVN para o cálculo da emissividade, foi inferior a $3{ }^{\circ} \mathrm{C}$. No entanto, o método utilizado para a determinação da emissividade pelo IDVN requer correção atmosférica nas bandas 1 e 2 do sensor AVHRR, o que não foi efetuado neste trabalho. Mesmo sendo o algoritmo de Ulivieri et al. (1994) o que apresenta a menor propagação de erros provindos de uma

\footnotetext{
${ }^{1}$ citados por Kerényi \& Putsay (2000)
} 
estimativa errada da emissividade (Pozo Vázquez et al., 1997), esta é a mais provável fonte de erro na estimativa das imagens de temperatura, subestimando as temperaturas.

Tabela 5. Temperaturas Mínima, Média e Máxima de cada composta mensal antes da correção para temperatura média mensal da bacia do Ji-Paraná, expresso em Celsius

\begin{tabular}{ccccc}
\hline Mês / Ano & Número de imagens & $\begin{array}{c}\text { Temp } \\
\text { Mínima }\left({ }^{\circ} \mathrm{C}\right)\end{array}$ & $\begin{array}{c}\text { Temp Média } \\
\left({ }^{\circ} \mathrm{C}\right)\end{array}$ & $\begin{array}{c}\text { Temp } \\
\text { Máxima }\left({ }^{\circ} \mathrm{C}\right)\end{array}$ \\
\hline Fevereiro 95 & 8 & 10 & 21 & 31 \\
Março 95 & 13 & 14 & 24 & 36 \\
Abril 95 & 16 & 14 & 23 & 28 \\
Maio 95 & 23 & 16 & 22 & 32 \\
Junho 95 & 31 & 21 & 26 & 34 \\
Julho 95 & 31 & 26 & 30 & 41 \\
Agosto 95 & 28 & 23 & 30 & 39 \\
Setembro 95 & 28 & 22 & 28 & 38 \\
Outubro 95* & $*$ & 22 & 26 & 35 \\
Novembro 96 & 17 & 11 & 22 & 33 \\
Dezembro 95 & 30 & 15 & 22 & 28 \\
Janeiro 96 & 28 & 12 & 20 & 26 \\
Fevereiro 96 & 15 & 14 & 22 & 29 \\
Março 96 & 23 & 14 & 22 & 28 \\
Abril 96 & 22 & 14 & 22 & 28 \\
Maio 96 & 31 & 20 & 25 & 28 \\
Junho 96 & 17 & 22 & 28 & 34 \\
Julho 96 & 27 & 27 & 31 & 36 \\
Agosto 96 & 19 & 25 & 29 & 34 \\
Setembro 96 & 16 & 19 & 27 & 35 \\
Outubro 96 & 14 & 20 & 27 & 34 \\
Novembro 96 & 16 & 11 & 23 & 31 \\
Dezembro 96 & 14 & 14 & 23 & 29 \\
\hline
\end{tabular}

Mesmo assim, as áreas com temperaturas extremas são pequenas. No caso da composta de fevereiro de $1995,9,4 \%$ da imagem possui temperaturas abaixo de $15^{\circ} \mathrm{C}$, sendo apenas $1,17 \%$ apresenta temperatura inferior a $11^{\circ} \mathrm{C}$ (Figura 26). Para novembro de 1996 , apenas $2,21 \%$ da imagem esta abaixo dos $15^{\circ} \mathrm{C}$ (Figura 27). 


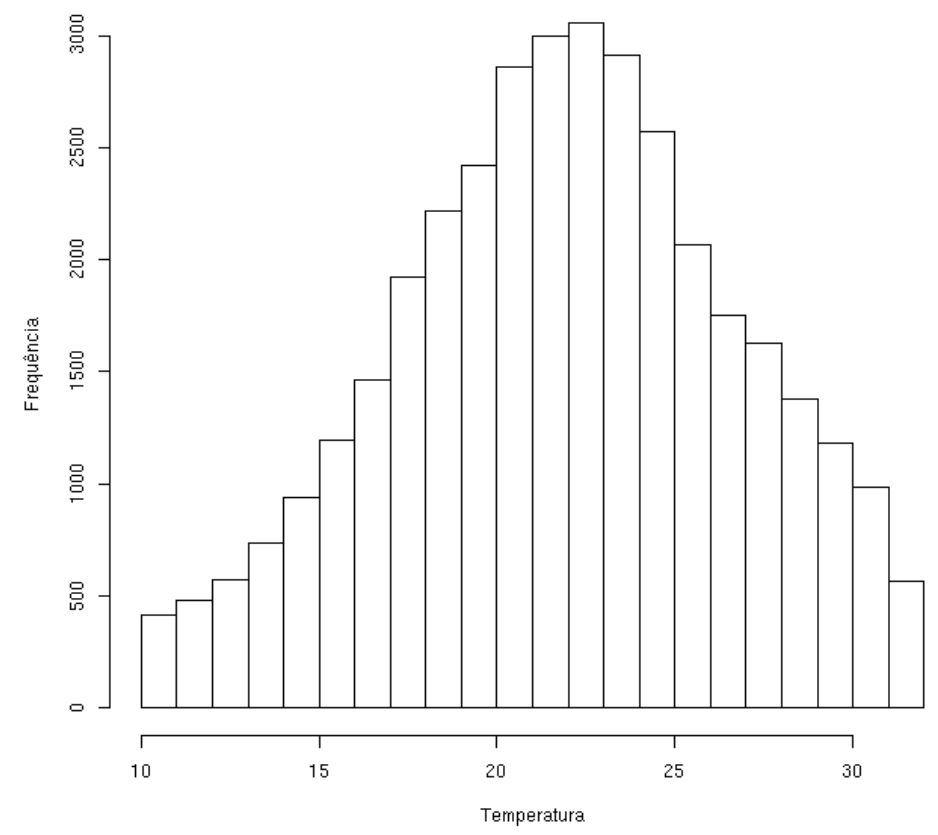

Figura 26 - Histograma de freqüência da imagem de temperatura mensal de Fevereiro de 1995, composta a partir de imagens diárias de AVHRR, na resolução de 1 x $1 \mathrm{~km}$, para a bacia do Ji-Paraná (temperatura em ${ }^{\circ} \mathrm{C}$ )

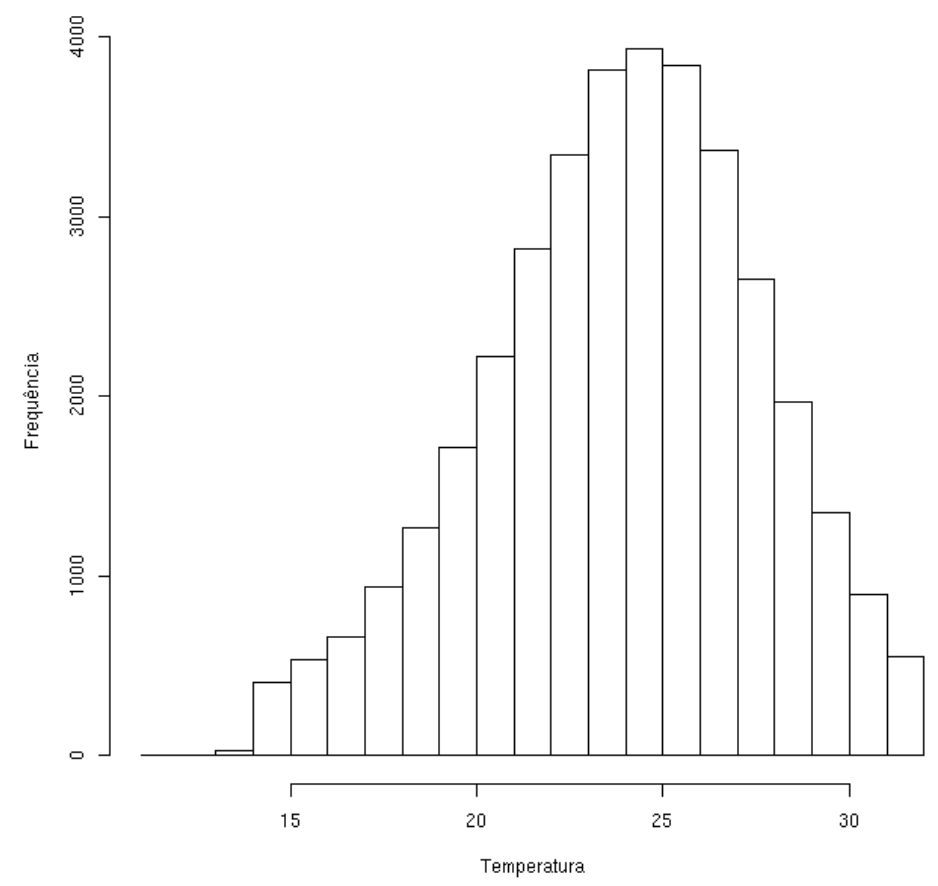

Figura 27 - Histograma de freqüência da imagem de temperatura mensal de Novembro de 1996, composta a partir de imagens diárias de AVHRR, na resolução de 1 x $1 \mathrm{~km}$, para a bacia do Ji-Paraná (temperatura $\mathrm{em}^{\circ} \mathrm{C}$ ) 


\subsubsection{Correção das imagens compostas de temperatura}

Comparando-se os valores das temperaturas mínima, média e máxima antes e após a correção (Tabela 5 e Tabela 6 , respectivamente), observa-se que a mesma reduziu as temperaturas muito altas encontradas em algumas imagens (redução de $11{ }^{\circ} \mathrm{C}$ em julho e $9{ }^{\circ} \mathrm{C}$ em agosto de 1995), além de elevar algumas temperaturas mínimas muito baixas. De modo geral, a correção reduziu a amplitude da imagem composta de temperatura em $6^{\circ} \mathrm{C}$, passando de $15^{\circ} \mathrm{C}$ para $9{ }^{\circ} \mathrm{C}$.

Tabela 6. Temperaturas mínima, média e máxima de cada composta mensal da bacia do Ji-Paraná, expresso em Celsius

\begin{tabular}{cccc}
\hline Mês - Ano & Temp Mínima $\left({ }^{\circ} \mathrm{C}\right)$ & Temp Média $\left({ }^{\circ} \mathrm{C}\right)$ & Temp Máxima $\left({ }^{\circ} \mathrm{C}\right)$ \\
\hline Fevereiro-95 & 13 & 20 & 26 \\
Março-95 & 16 & 21 & 27 \\
Abril-95 & 16 & 21 & 24 \\
Maio-95 & 17 & 20 & 26 \\
Junho-95 & 19 & 22 & 26 \\
Julho-95 & 22 & 25 & 30 \\
Agosto-95 & 20 & 25 & 30 \\
Setembro-95 & 20 & 24 & 30 \\
Outubro-95 & 20 & 23 & 29 \\
Novembro-95 & 13 & 21 & 26 \\
Dezembro-95 & 16 & 21 & 24 \\
Janeiro-96 & 14 & 20 & 23 \\
Fevereiro-96 & 15 & 21 & 25 \\
Março-96 & 16 & 20 & 24 \\
Abril-96 & 16 & 20 & 24 \\
Maio-96 & 19 & 22 & 24 \\
Junho-96 & 20 & 24 & 27 \\
Julho-96 & 23 & 25 & 29 \\
Agosto-96 & 22 & 24 & 27 \\
Setembro-96 & 18 & 23 & 29 \\
Outubro-96 & 19 & 24 & 28 \\
Novembro-96 & 13 & 22 & 26 \\
Dezembro-96 & 16 & 21 & 25 \\
\hline
\end{tabular}

No entanto, a correção também reduziu as temperaturas médias das imagens compostas excessivamente, fazendo com que para certos meses, a temperatura média da 
imagem estivesse abaixo das temperaturas mínimas normais da região (Figura 28). A mesma correção também reduziu em muito as temperaturas mínimas das imagens compostas (Figura 29). Além disso, as temperaturas medidas nas torres meteorológicas do projeto ABRACOS mostram que a temperatura média mensal durante os anos de 1995 e 1996 se assemelham à média normal (Figura 10, pág. 23). Isso indica que a correção das imagens compostas, utilizando a relação entre a temperatura máxima e média de cada mês, não foi eficiente.

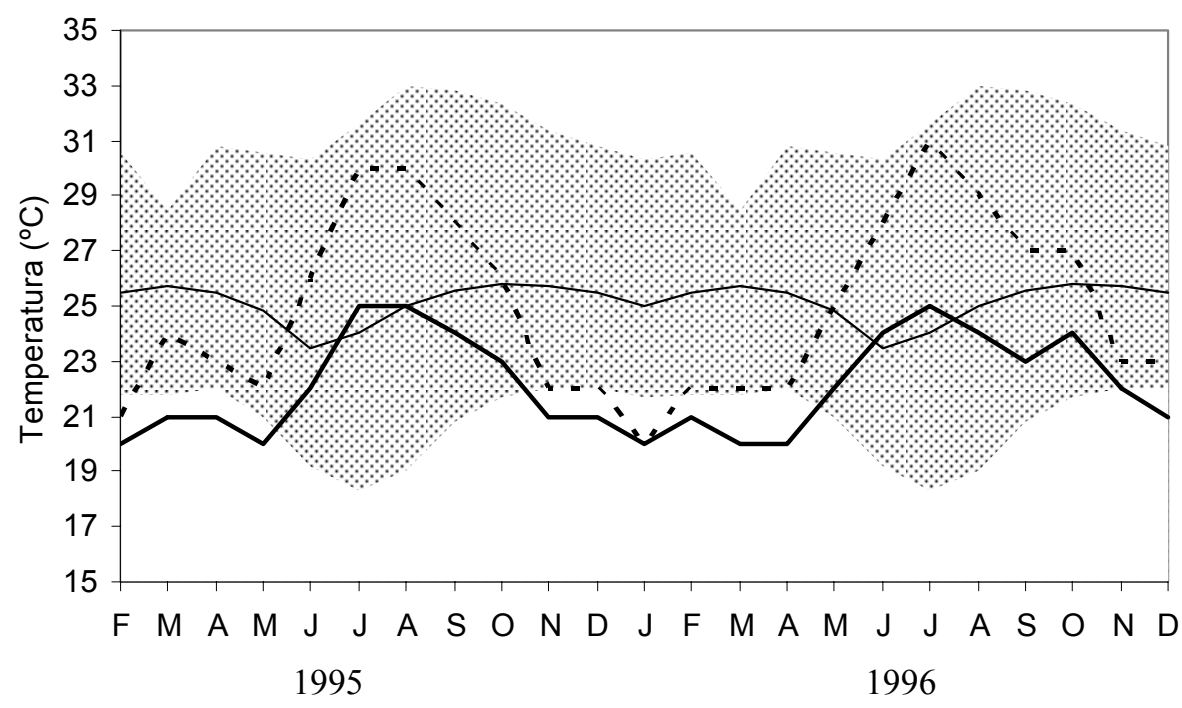

- - - - sem correção — com correção — Normal histórica

Figura 28 - Temperatura média da bacia do Ji-Paraná, a partir da composta mensal do sensor AVHRR, sem a correção e com a correção devido ao horário de passagem do satélite, para os anos de 1995 e 1996. Faixa pontilhada representa o intervalo entre as temperaturas máxima e mínima normais de Porto Velho (INMET) 


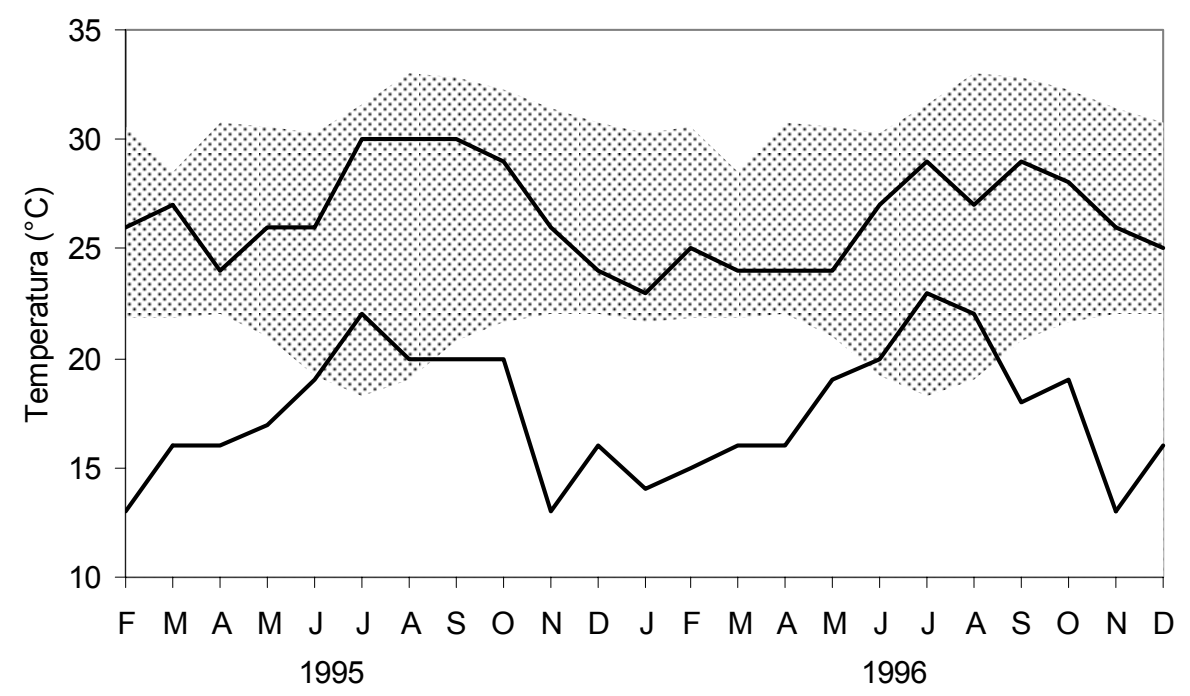

Amplitude das imagens corrigidas

Figura 29 - Temperaturas máxima e mínima das imagens compostas corrigidas pelo filtro de máxima vs. média (linhas contínuas), comparada as temperaturas máxima e mínima normais de Porto Velho (RO) (INMET)

Estas constatações, aliadas ao fato que as evapotranspirações potenciais, calculadas com as imagens compostas mensais corrigidas utilizando o método da relação entre a temperatura máxima e média, foram interiores a evapotranspiração real calculada pelo balanço de massa, e a falta da correção atmosférica para o cálculo do IDVN, indicam que as temperaturas médias mensais das imagens compostas estão subestimadas.

Foi então utilizada uma outra correção para as imagens compostas mensais, baseadas no fato das temperaturas médias do período estarem próximas à normal, possibilitando a correção dessas à partir dos dados climáticos da região, conforme descrito no item 2.6.6. Foi escolhido um fator de 0,7 pois este mostrou-se suficiente para elevar a temperatura média das imagens compostas mensais a valores próximos da temperatura média normal, além de manter as temperaturas máximas e mínimas de cada imagem dentro da faixa que compreende as temperaturas máximas e mínimas normais (Figura 30). 


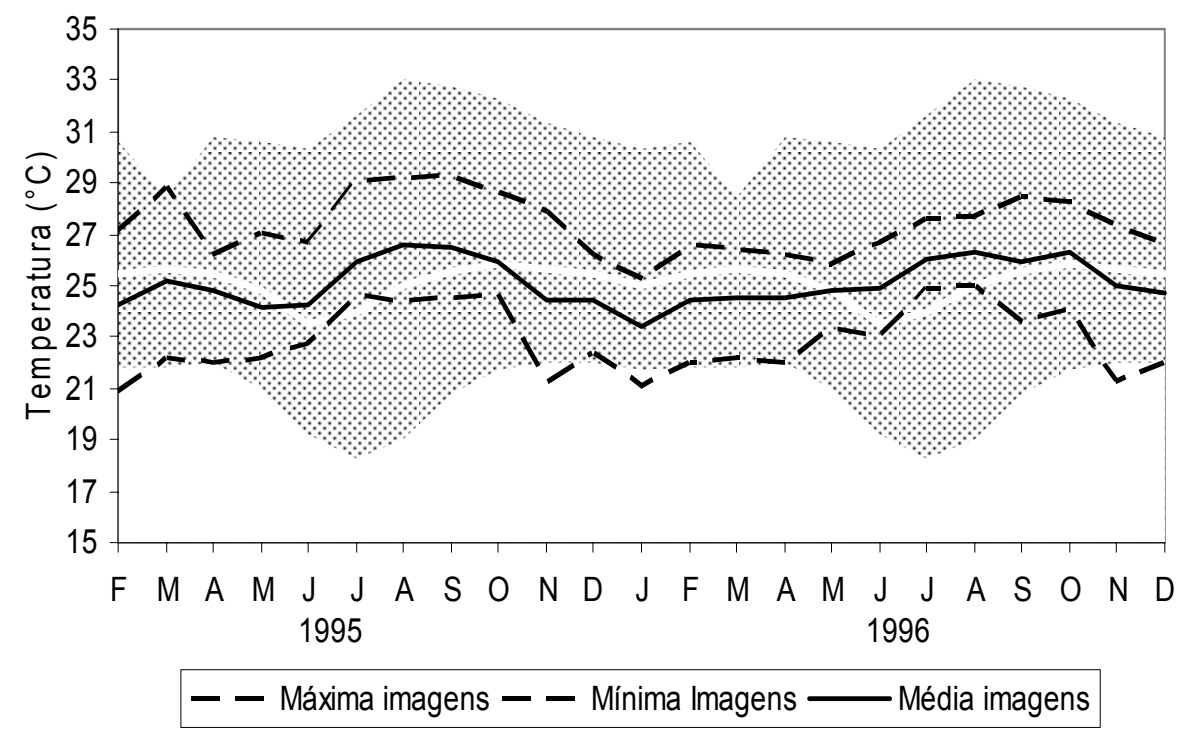

Figura 30 - Temperaturas máxima, mínima e média das imagens compostas mensais corrigidas utilizando a temperatura média normal, comparadas à amplitude térmica normal (faixa pontilhada) e à média climatológica (linha branca na faixa pontilhada)

Enquanto a correção que relaciona a máxima mensal com a média é eficiente na remoção das temperaturas muito elevadas, esta não é capaz de corrigir as temperaturas muito baixas, como $13^{\circ} \mathrm{C}$ em fevereiro e dezembro de 1995 , fazendo com que a amplitude térmica de cada imagem seja muito elevada. Já a correção utilizando a temperatura média normal reduziu as temperaturas muito elevadas a valores semelhantes aos obtidos com a primeira correção, além de aumentar as temperaturas muito baixas, mantendo a variação da imagem dentro da variação mensal normal (Figura 31). 


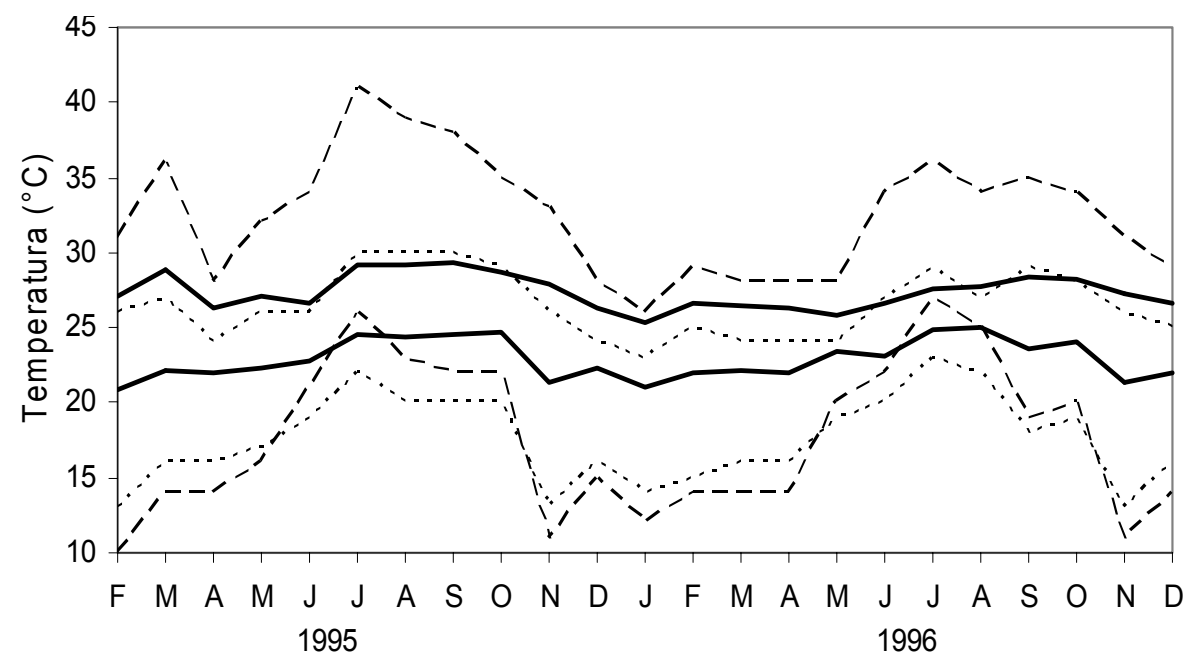

- - - - Original ....... Filtro Máx vs. Méd _ Filtro Normal

Figura 31 - Temperaturas máximas e mínimas das imagens compostas mensais originais (tracejado), corrigidas pela relação Máx vs. Méd (pontilhado) e corrigidas utilizando-se a média normal (preto).

As imagens compostas de temperatura mensal (Figura 32 e 33), quando contrapostas ao mapa de cobertura vegetal (Figura 5, pág. 19), indicam que nos meses mais secos (junho, julho e agosto) as temperaturas nas áreas de pastagem são mais elevadas que as das áreas florestadas. Lyra et al. (1997) mostram que, o fato das pastagens possuírem uma menor quantidade de água disponível, resulta em déficit hídrico nos meses mais secos. Com isso, a energia disponível na superfície é convertida em calor sensível, aquecendo a superfície. O inverso ocorre nas áreas florestadas que, devido à maior disponibilidade hídrica, mantêm a evapotranspiração nos meses mais secos, convertendo a energia disponível na superfície em calor latente, sem aquecimento. Medidas da razão de Bowen ( $\beta=$ calor sensível / calor latente) efetuadas na região de estudo, mostram que nos meses secos existe uma maior quantidade de calor sensível sobre a pastagem $(\beta=1,02)$, enquanto sobre a floresta o fluxo de calor latente é maior $(\beta=0,12)$ (Lyra et al., 1997). O mesmo não acontece nos meses chuvosos, uma vez que existe água disponível nas pastagens. 

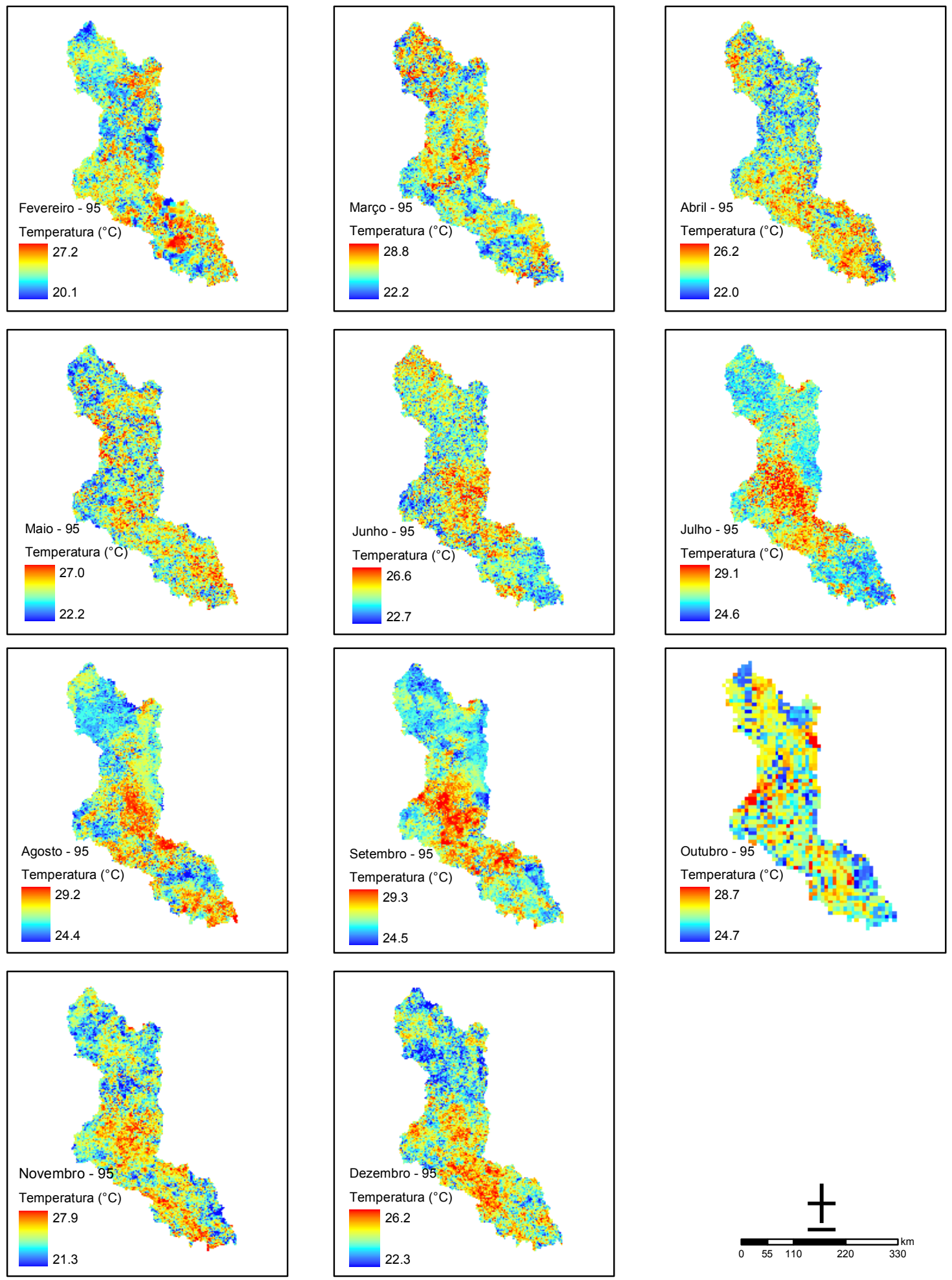

Figura 32 - Imagens compostas de temperatura mensal para o ano de 1995, resolução de $1 \mathrm{~km}$ da bacia do Ji-Paraná. A imagem de outubro tem resolução de $8 \mathrm{~km}$ 

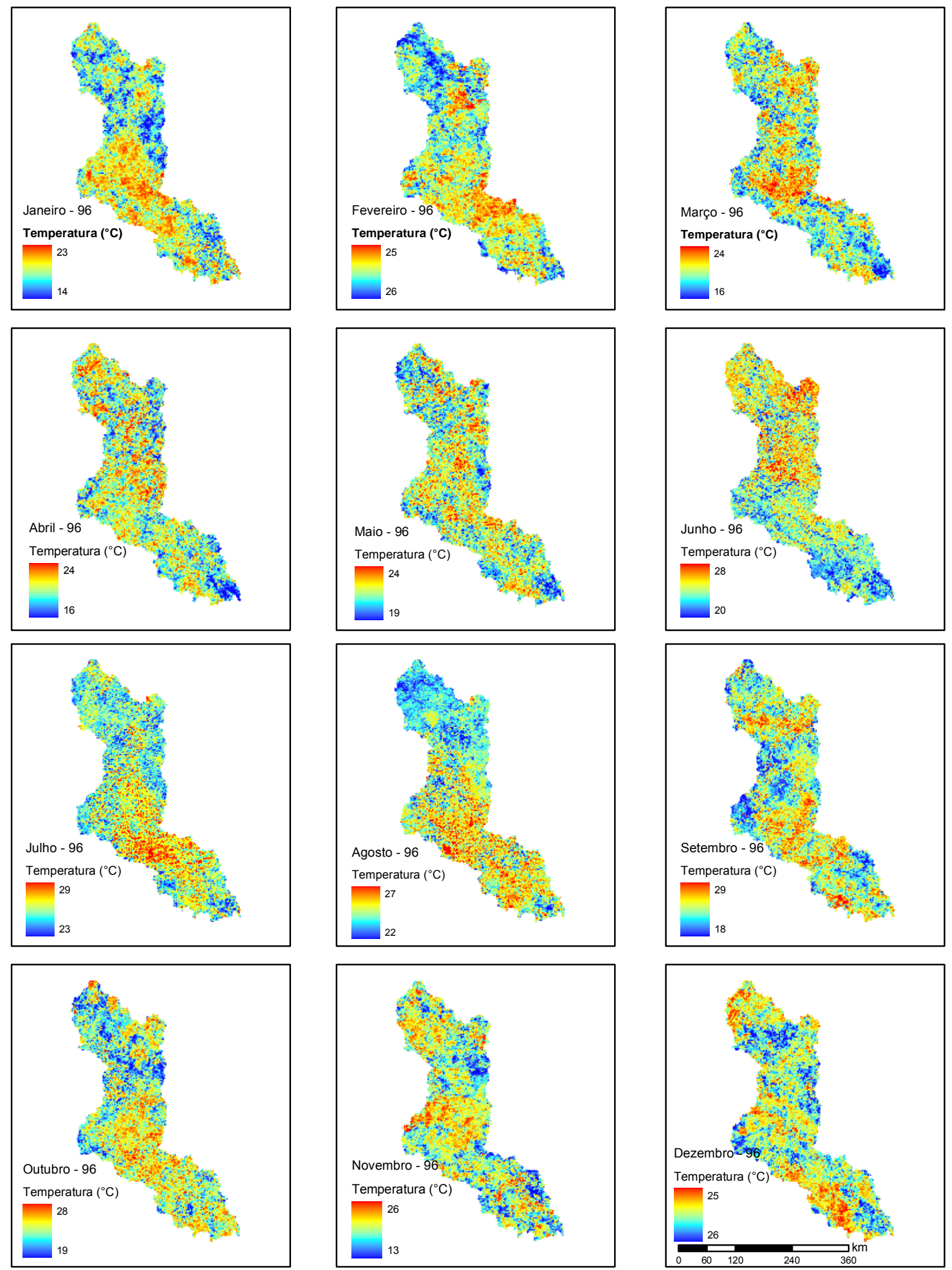

Figura 33 - Imagens compostas de temperatura mensal para o ano de 1996, resolução de 1 km, da bacia do Ji-Paraná 
No entanto, a diferença observada na temperatura média sobre pastagem e floresta é pequena. Em média, a temperatura da pastagem foi apenas $0,23{ }^{\circ} \mathrm{C}$ mais elevada que a da floresta ao longo dos dois anos (Tabela 7). Esta diferença é menor que o desvio padrão das temperaturas sobre as duas coberturas. Vale ressaltar que esta é uma temperatura média mensal e não contempla a variação diurna da temperatura, onde se encontram as maiores diferenças entre as temperaturas sobre pasto e floresta, uma vez que a amplitude térmica da pastagem é superior a da floresta (Culf, et al., 1996). Embora importante, essa variação diurna não pode ser medida pelo método aqui utilizado, pois o sensor orbital faz apenas uma observação por dia.

Tabela 7. Temperaturas médias e desvio padrão das imagens compostas mensais nas áreas de floresta e pastagem da bacia do Ji-Paraná

\begin{tabular}{|c|c|c|c|c|c|}
\hline & \multicolumn{2}{|c|}{ Pastagem } & \multicolumn{2}{|c|}{ Floresta } & \multirow{2}{*}{$\begin{array}{c}\text { Média } \\
\text { Pastagem - } \\
\text { Floresta } \\
\left({ }^{\circ} \mathrm{C}\right) \\
\end{array}$} \\
\hline & Média $\left({ }^{\circ} \mathrm{C}\right)$ & $\begin{array}{l}\text { Desvio } \\
\text { Padrão }\end{array}$ & Média $\left({ }^{\circ} \mathrm{C}\right)$ & $\begin{array}{l}\text { Desvio } \\
\text { Padrão }\end{array}$ & \\
\hline Fev-95 & 24,41 & 1,42 & 24,16 & 1,42 & 0,24 \\
\hline Mar-95 & 25,21 & 0,99 & 25,19 & 1,02 & 0,01 \\
\hline Abr-95 & 24,94 & 0,68 & 24,74 & 0,69 & 0,19 \\
\hline Mai-95 & 24,17 & 0,66 & 24,08 & 0,67 & 0,09 \\
\hline Jun-95 & 24,32 & 0,56 & 24,20 & 0,48 & 0,11 \\
\hline Jul-95 & 26,15 & 0,60 & 25,75 & 0,45 & 0,40 \\
\hline Ago-95 & 26,74 & 0,67 & 26,43 & 0,55 & 0,31 \\
\hline Set-95 & 26,84 & 0,86 & 26,22 & 0,72 & 0,61 \\
\hline Out-95 & 25,95 & 0,51 & 25,93 & 0,53 & 0,01 \\
\hline Nov-95 & 24,71 & 0,87 & 24,32 & 0,85 & 0,39 \\
\hline Dez-95 & 24,70 & 0,71 & 24,27 & 0,71 & 0,43 \\
\hline Jan-96 & 23,55 & 0,78 & 23,32 & 0,76 & 0,23 \\
\hline Fev-96 & 24,57 & 0,97 & 24,32 & 0,93 & 0,25 \\
\hline Mar-96 & 24,59 & 0,75 & 24,42 & 0,69 & 0,16 \\
\hline Abr-96 & 24,62 & 0,72 & 24,50 & 0,70 & 0,11 \\
\hline Mai-96 & 24,92 & 0,42 & 24,71 & 0,43 & 0,20 \\
\hline Jun-96 & 24,94 & 0,51 & 24,82 & 0,47 & 0,12 \\
\hline Jul-96 & 26,31 & 0,41 & 25,89 & 0,41 & 0,41 \\
\hline Ago-96 & 26,61 & 0,46 & 26,18 & 0,47 & 0,42 \\
\hline Set-96 & 25,99 & 0,72 & 25,85 & 0,59 & 0,14 \\
\hline Out-96 & 26,49 & 0,74 & 26,18 & 0,73 & 0,31 \\
\hline Nov-96 & 25,02 & 1,14 & 24,99 & 1,08 & 0,03 \\
\hline Dez-96 & 24,72 & 0,87 & 24,65 & 0,84 & 0,06 \\
\hline Média & 25,24 & & 25,01 & & 0,23 \\
\hline
\end{tabular}


Convertendo o mapa de cobertura em uma máscara binária com o valor 1 para floresta e 0 para pastagem, rebrota e cerrado, pode-se então correlacionar espacialmente as imagens compostas de temperatura mensal com o uso/cobertura da bacia (r). Valores negativos indicam que, à medida que passamos da pastagem (0) para a floresta (1), a temperatura diminui, ou seja, existe uma correlação inversa entre dominância da floresta e a temperatura da imagem composta mensal de temperatura (Tabela 8)

Tabela 8. Índices de correlação espacial entre as imagens compostas de temperatura e o mapa de cobertura da bacia do Ji-Paraná nos meses de fevereiro de 1995 a dezembro de 1996

\begin{tabular}{ccc}
\hline & \multicolumn{2}{c}{ Correlação entre cobertura e } \\
& $\mathrm{r}$ & $\mathrm{r}^{2}$ \\
\hline Fev-95 & $-0,088$ & 0,007744 \\
Mar-95 & $-0,009$ & 0,000081 \\
Abr-95 & $-0,145$ & 0,021025 \\
Mai-95 & $-0,072$ & 0,005184 \\
Jun-95 & $-0,104$ & 0,010816 \\
Jul-95 & $-0,348$ & 0,121104 \\
Ago-95 & $-0,247$ & 0,061009 \\
Set-95 & $-0,359$ & 0,128881 \\
Out-95 & $-0,021$ & 0,000441 \\
Nov-95 & $-0,213$ & 0,045369 \\
Dez-95 & $-0,3$ & 0,09 \\
Jan-96 & $-0,14$ & 0,0196 \\
Fev-96 & $-0,121$ & 0,014641 \\
Mar-96 & $-0,106$ & 0,011236 \\
Abr-96 & $-0,078$ & 0,006084 \\
Mai-96 & $-0,231$ & 0,053361 \\
Jun-96 & $-0,128$ & 0,016384 \\
Jul-96 & $-0,436$ & 0,190096 \\
Ago-96 & $-0,407$ & 0,165649 \\
Set-96 & $-0,104$ & 0,010816 \\
Out-96 & $-0,195$ & 0,038025 \\
Nov-96 & $-0,023$ & 0,000529 \\
Dez-96 & $-0,034$ & 0,001156 \\
\hline
\end{tabular}

Apesar dos valores de $\mathrm{r}^{2}$ estarem muito baixos, algumas informações importantes podem ser obtidas dos índices de correlação. Conforme esperado, a correlação (r) aumenta (fica mais negativa) à medida que a diferença entre a temperatura média da 
pastagem e da floresta se acentua. Porém, observa-se que os meses secos (março a agosto) apresentam maior correlação entre temperatura e cobertura do solo do que os meses chuvosos (Figura 34). Para uma mesma diferença entre a temperatura média das duas coberturas nas imagens compostas mensais, as imagens da época seca apresentam maior correlação espacial do que as da época chuvosa. É importante lembrar que a correção utilizando a normal climatológica reduziu a amplitude das imagens de temperatura. Porém, ainda assim é possível notar nas imagens compostas que, no período seco, a diferenciação entre as temperaturas sobre as duas coberturas é maior que no período chuvoso, devido às diferenças entre as relações entre calor sensível e latente (Lyra et al., 1997).

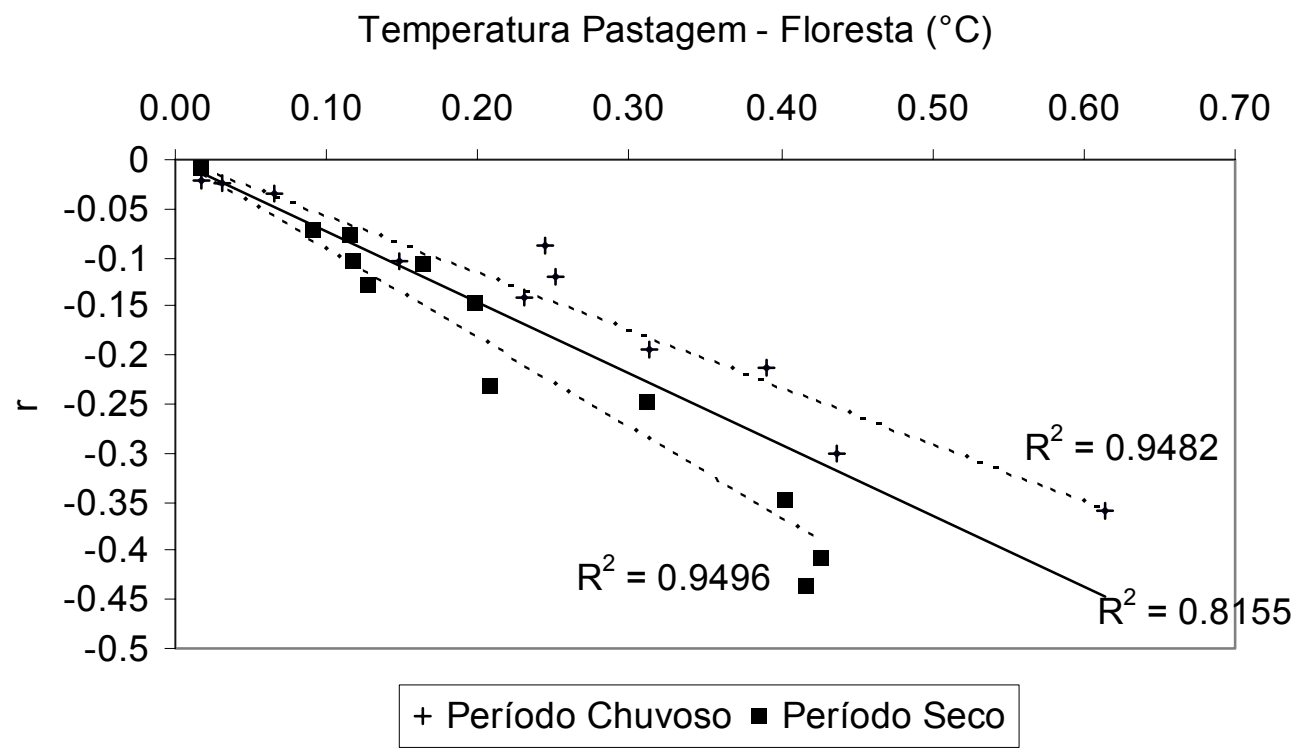

Figura 34 - Relação entre a diferença entre temperatura média sobre pastagem e floresta e a correlação espacial entre a máscara de floresta e a imagem composta de temperatura. Note que, independentemente da diferença das temperaturas médias entre as das coberturas, a correlação espacial é sempre maior (mais negativa) para os meses secos 


\subsection{Evapotranspiração potencial}

A evapotranspiração potencial anual da bacia Ji-Paraná, para o ano hidrológico de setembro de 1995 a agosto de 1996 foi de $1379 \mathrm{~mm}$. Os meses com as maiores taxas de evapotranspiração potencial acompanham os meses com as temperaturas mais elevadas (Figura 35), estando em torno de $140 \mathrm{~mm}$ nos meses de outubro.

Conforme esperado, as imagens de evapotranspiração potencial (Figura 36 e 37) apresentam grande semelhança com as de temperatura (Figura 32 e 33), uma vez que pelo modelo de Thornthwaite, a temperatura média mensal é a única variável utilizada no cálculo da evapotranspiração potencial.

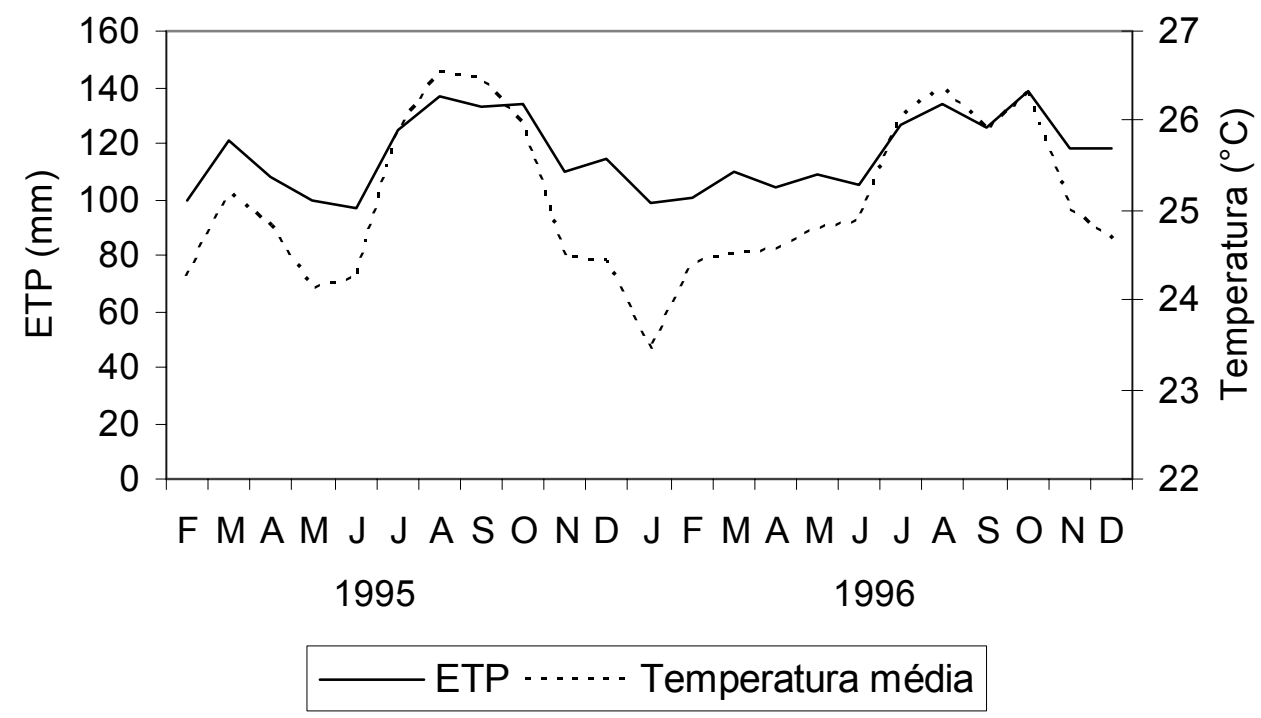

Figura 35 - Evapotranspiração potencial (ETP) e temperatura média da bacia ao longo do período de estudo 

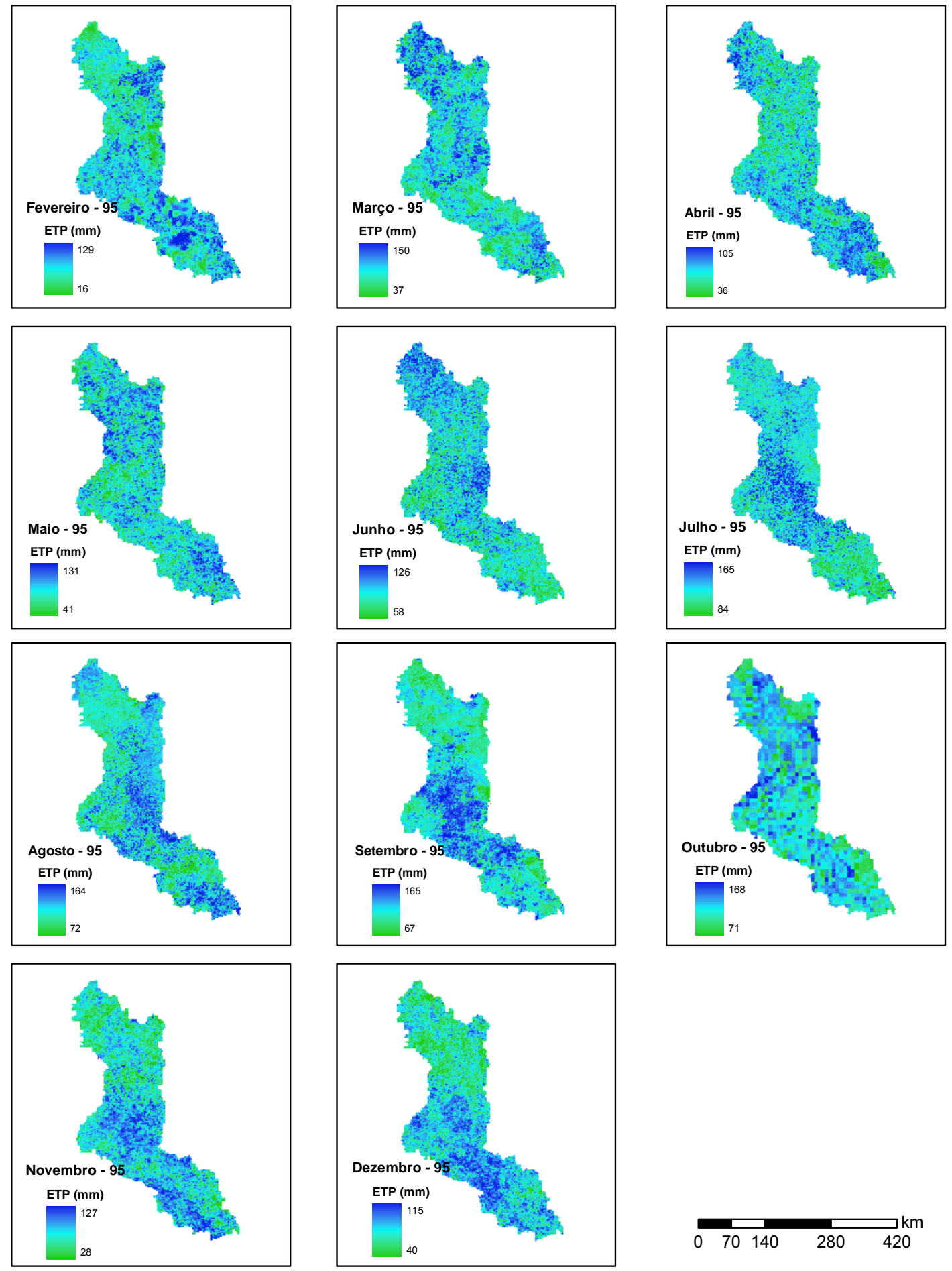

Figura 36 - Evapotranspiração potencial (ETP) modelada na bacia do Ji-Paraná pelo método de Thornthwaite para o ano de 1995 

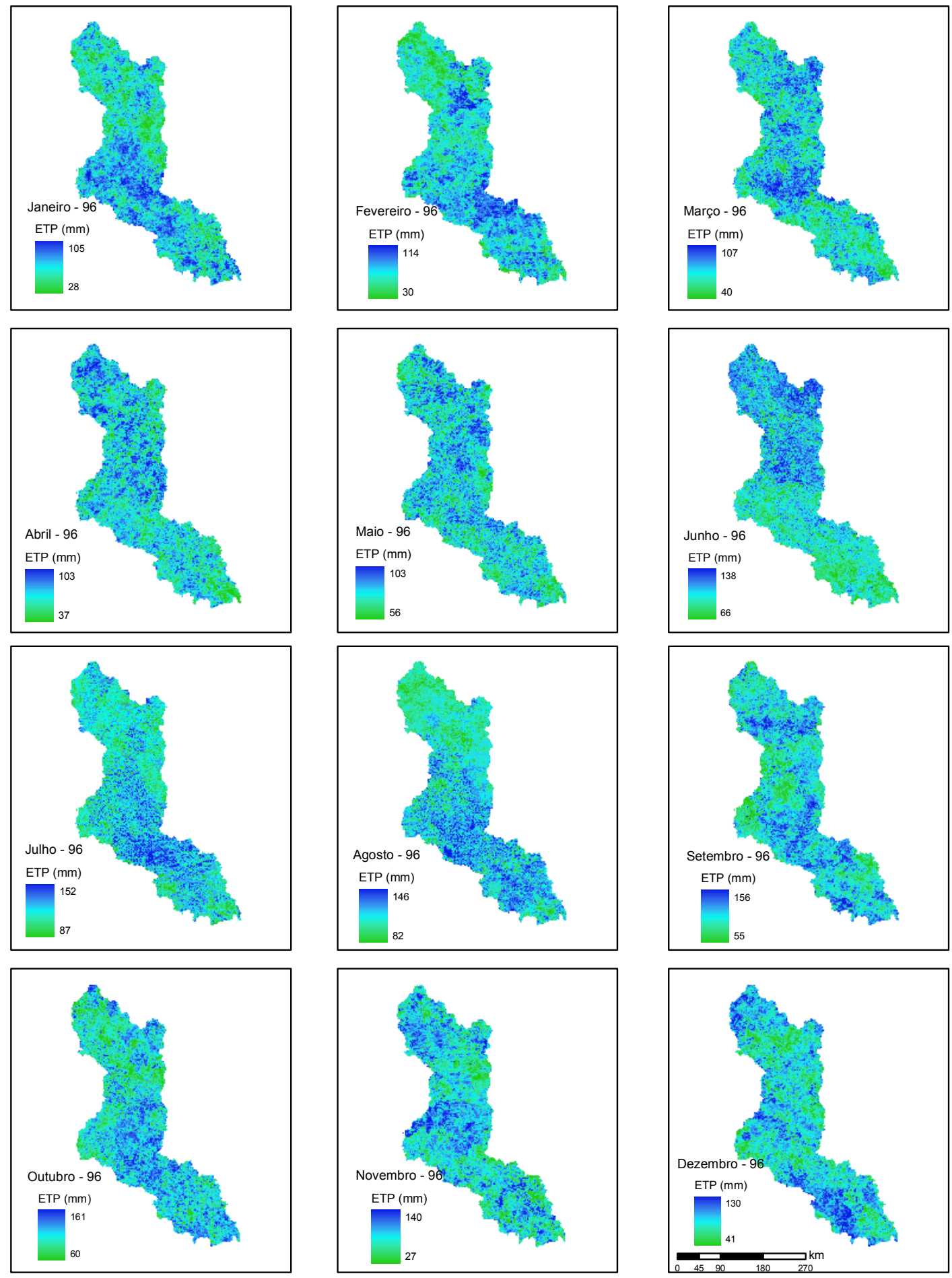

Figura 37 - Evapotranspiração potencial modelada na bacia do Ji-Paraná pelo método de Thornthwaite para o ano de 1996 


\subsection{Capacidade de água disponível}

\subsubsection{Mapa de teor de argila e classe textural}

O teor médio de argila da bacia é de $30 \%$, variando de 6 a $76 \%$ (Figura 38a). A maior parte da bacia (61\%) apresenta solos com textura média. Solos com textura argilosa ou muito argilosa totalizam $32 \%$ da área. O restante (7\%) possui textura arenosa, estando a maior parte na porção sudeste da bacia (Figura 38b).

Devido à menor quantidade de pontos amostrais na porção norte da bacia, a interpolação gerou algumas feições improváveis, como quebras bruscas e retas nos mapas de teor de argila (Figura 38a). Estas poderiam ser removidas e a interpolação melhorada, utilizando-se mapas pedológicos e geológicos da bacia no modelo geoestatístico. Porém, tal estudo excederia o objetivo deste trabalho. No entanto, a maioria dessas feições é removida quando o mapa de teor de argila é reclassificado em classes texturais (Figura 38b), restando apenas algumas áreas problemáticas. Estas, devido à natureza do modelo, propagam-se para o mapa de CAD (Figura 39) e para os resultados finais (Figura 44), principalmente nos mapas de evapotranspiração das épocas secas. 


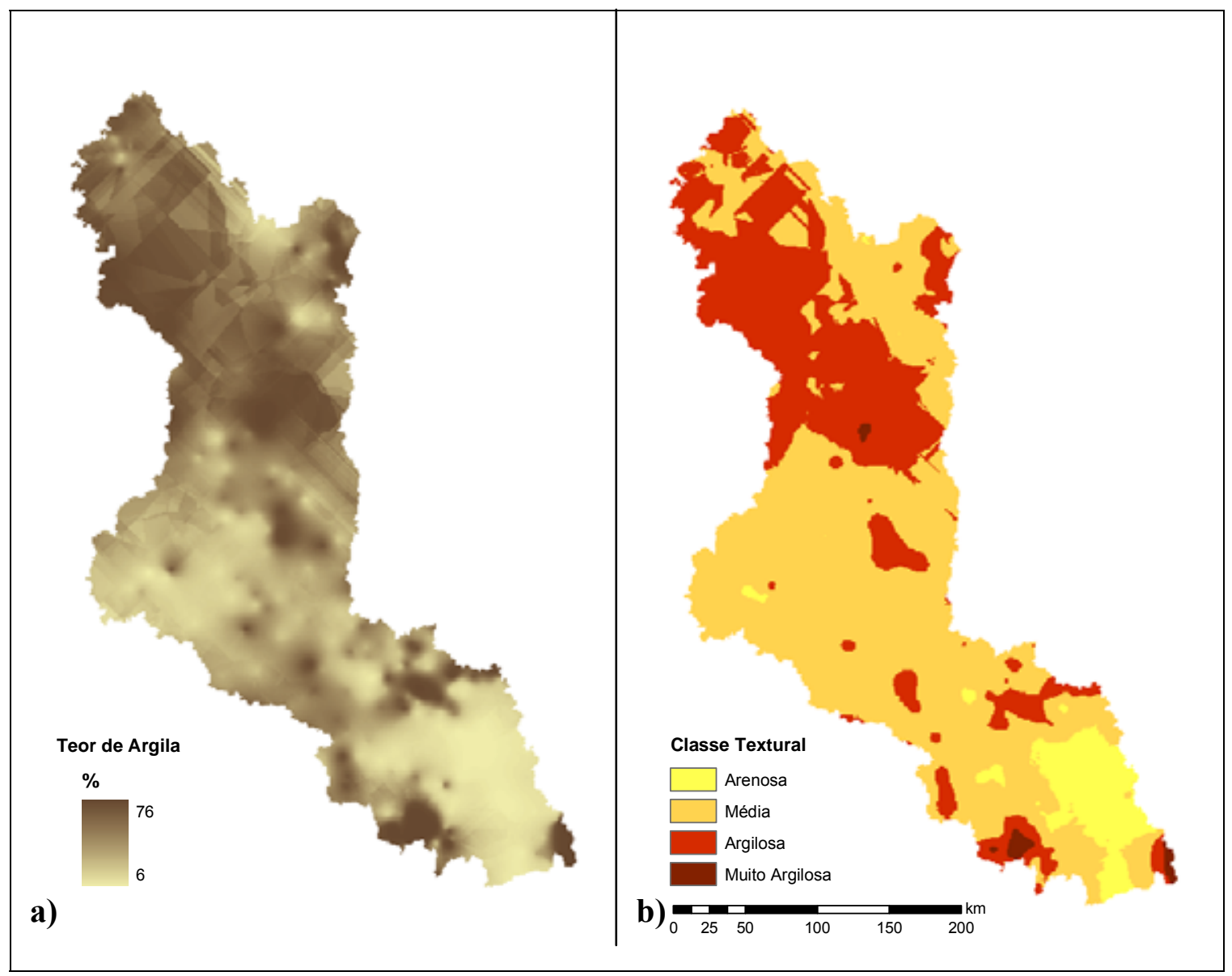

Figura 38 - a) Teores de argila e b) Classes texturais da bacia do Ji-Paraná

\subsubsection{Mapa da capacidade de água disponível (CAD)}

A CAD é influenciada tanto pela classe textural do solo, quanto pela cobertura, que define a profundidade de solo explorado pelas raízes. A grande pressão antrópica a qual a bacia do Ji-Paraná está submetida fez com que, em 1996, esta apresentasse $28 \%$ de sua cobertura nativa substituída por pastagens (Hanada, 2004) influenciando a CAD, principalmente na porção sul e central da bacia, onde se concentra o desmatamento (Figura 39). A CAD média nas áreas de pastagem foi de $165 \mathrm{~mm}$ enquanto que esta foi de $430 \mathrm{~mm}$ nas áreas de floresta.

Alterações dessa natureza podem afetar o funcionamento hidrológico da bacia como um todo, uma vez que, a conversão para pastagens reduz a quantidade de água 
disponível para a evapotranspiração (redução da CAD). Além disso, alteram outras propriedades hidrológicas, como a interceptação da precipitação, modificação da condutividade hidráulica e aumento do escoamento superficial (Bruijnzeel, 1996). Muitos trabalhos realizados em micro-bacias $\left(<1 \mathrm{~km}^{2}\right)$ mostram que o desmatamento resulta em aumento da vazão dos rios (Bosch \& Hewlett, 1982). Mais recentemente, Costa et al. (2003) observaram este mesmo resultado em uma bacia de meso escala (175.360 km² - Estação Porto Nacional, Rio Tocantins), comprovando que a alteração do uso do solo afeta o regime hidrológico de grandes áreas tropicais. Portanto, o crescente desmatamento nesta bacia tem como conseqüência a redução da água disponível, o que pode resultar na redução da evapotranspiração, além da intensificação do déficit hídrico da bacia.

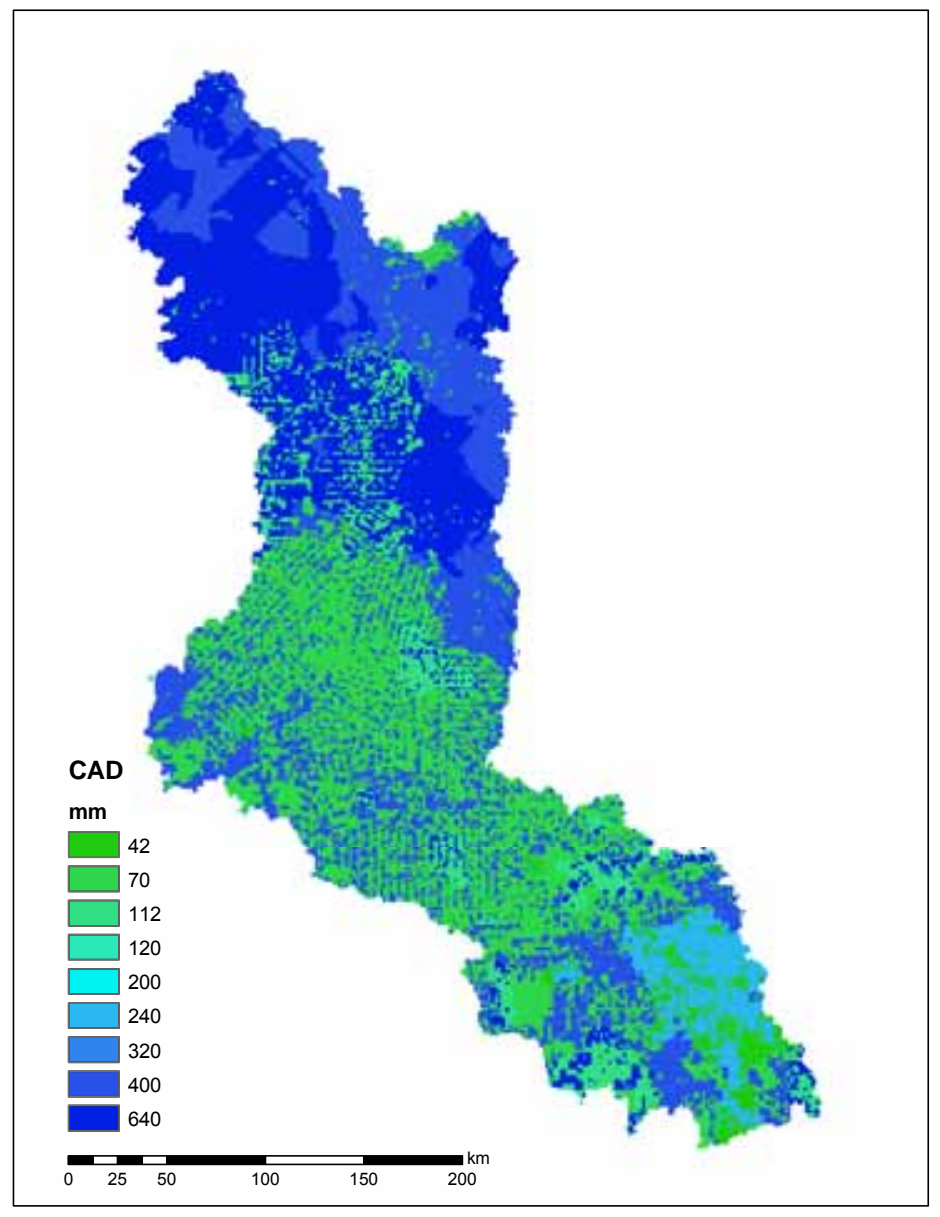

Figura 39 - Capacidade de Água disponível (CAD) da bacia do Ji-Paraná 
A CAD média da bacia foi de $325 \mathrm{~mm}$, variando de $42 \mathrm{~mm}$ a $640 \mathrm{~mm}$. Das subbacias estudadas, a que apresentou a maior CAD foi Mineração Jacunda (592 mm) e a menor, a sub-bacia Jaru $(197 \mathrm{~mm})$. Esta diferença se dá devido a dois fatores. Primeiramente, todos os solos da sub-bacia Mineração Jacunda possuem textura argilosa. Os solos da sub-bacia Jaru possuem textura média. Além disso, a sub-bacia Mineração Jacunda possui apenas $10 \%$ de sua área com pastagens, sendo que o restante está recoberto por florestas. Já a sub-bacia Jaru apresenta mais de $61 \%$ de sua área coberta por pastagens.

Como será visto mais adiante, alterações na CAD modificam o comportamento do modelo, principalmente quanto ao déficit e excedente hídrico.

\subsection{Balanço hídrico da bacia do Ji-Paraná}

A modelagem hidrológica da bacia do Ji-Paraná mostra que esta apresenta, claramente, um período de déficit hídrico, com início em junho e estendendo-se até outubro (Figura 40). Este período de seca se inicia a partir do momento em que as chuvas na região tornam-se insuficientes para suprir a demanda atmosférica, ocasionando a diferenciação entre a evapotranspiração real (ETr) e potencial (ETP). Este resultado indica que o funcionamento do modelo foi coerente ao longo do tempo.

O período de déficit também está em concordância com os dados climáticos da região (Figura 41), com déficit hídrico de junho a outubro. No entanto, a intensidade do déficit hídrico obtido utilizando-se as normais de Porto Velho é inferior ao modelado. Isto ocorre porque a precipitação normal em Porto Velho é superior à precipitação média da bacia (2354 mm e $2043 \mathrm{~mm}$, respectivamente), principalmente no período de seca. Também existe um pico na precipitação normal no mês de agosto, que não é observado na precipitação média interpolada (Figura 15). Outro fato importante é que Porto Velho se encontra fora da bacia do Ji-Paraná, podendo ter o balanço hídrico distinto do balanço médio da bacia estudada. 


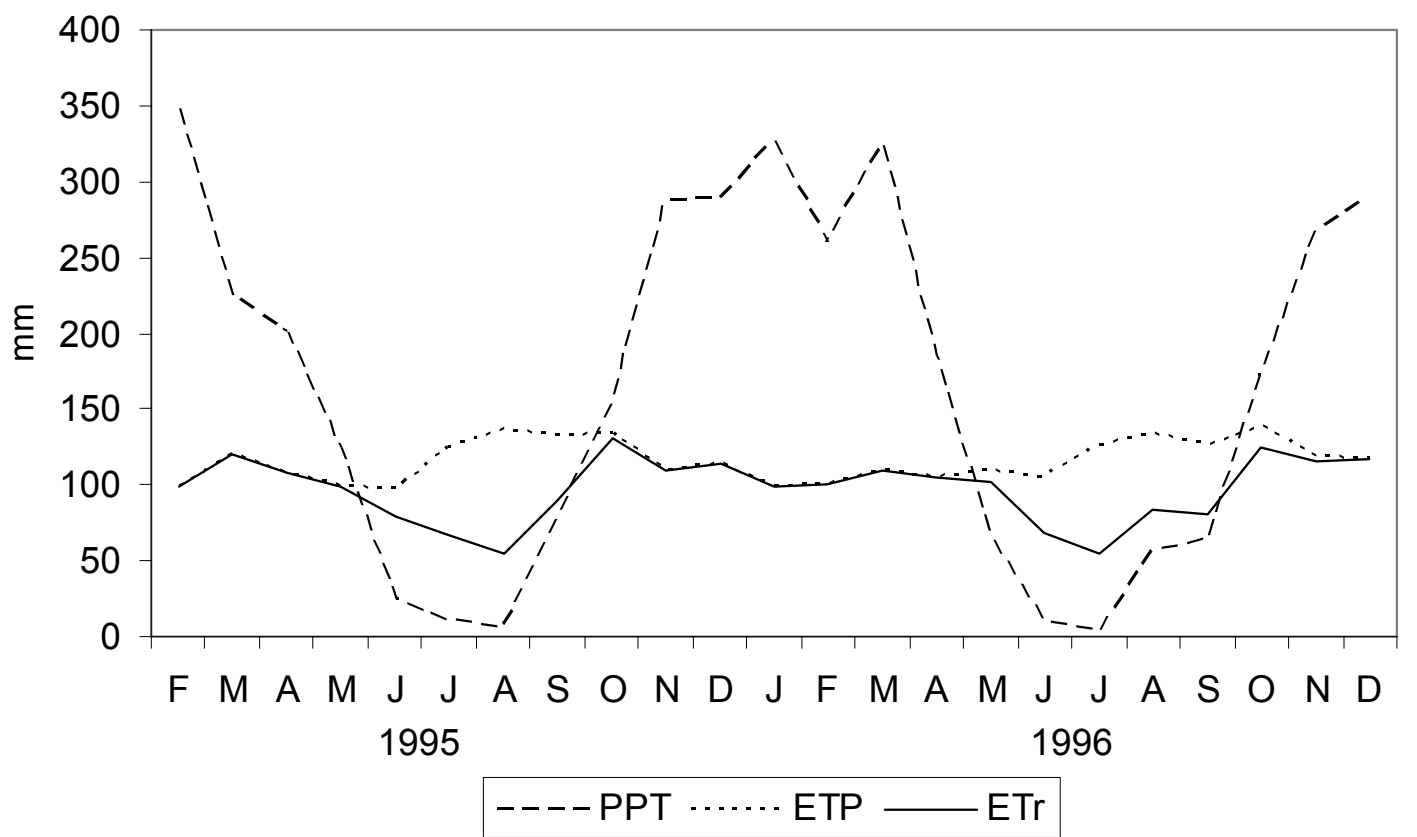

Figura 40 - Balanço hídrico modelado para a bacia do Ji-Paraná. PPT = Precipitação; ETP = Evapotranspiração potencial e ETr = Evapotranspiração real

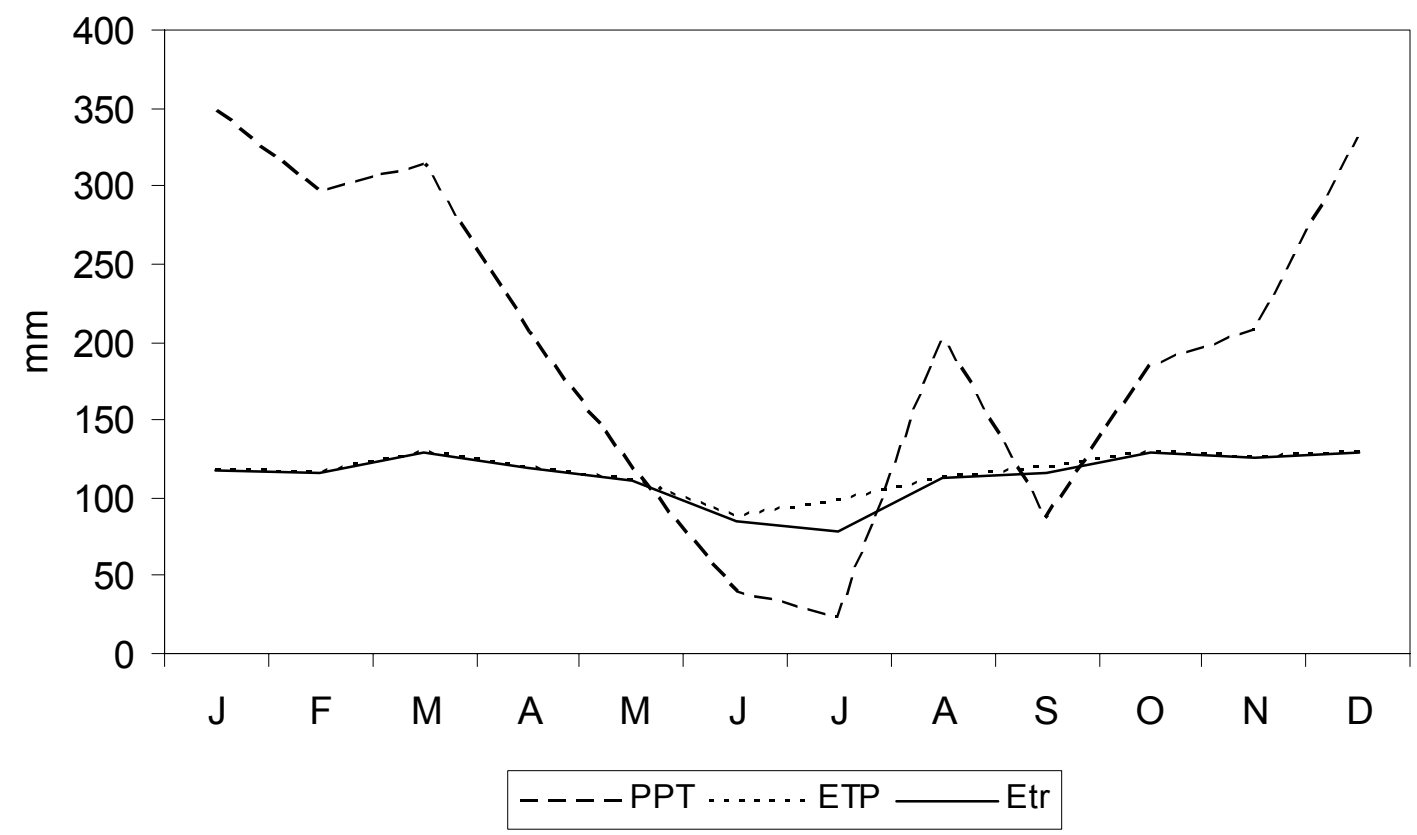

Figura 41 - Balanço hídrico normal mensal para Porto Velho com CAD igual a 300 mm (FONTE: Sentelhas, 1999) 
A evapotranspiração potencial de toda a bacia do Ji-Paraná durante o período estudado foi de $1379 \mathrm{~mm}^{-1}$ (cerca de $3,8 \mathrm{~mm} \mathrm{dia}^{-1}$ ), com a máxima ocorrendo nos meses de agosto a outubro (139 mm em outubro de 1996, aprox. 4,5 mm dia ${ }^{-1}$ ) e a mínima nos meses de maio e junho para o ano de 1995 (96 mm em junho, ou 3,2 mm $\mathrm{dia}^{-1}$ ) e janeiro e fevereiro, em 1996 (100 mm em janeiro; aprox. 3,2 mm dia ${ }^{-1}$ ). Esta sazonalidade da evapotranspiração potencial acompanha a variação da temperatura (Figura 35).

Estimativas da evapotranspiração potencial efetuadas para a Reserva Duke (região central da Amazônia, próxima a Manaus), mostram que esta é, em média, $4 \mathrm{~mm}$ $\operatorname{dia}^{-1}$, com a máxima ocorrendo nos meses de agosto a outubro. A evapotranspiração potencial anual foi estimada em $1503 \mathrm{~mm}$, utilizando o método de Thornthwaite (1948) e 1573 mm, utilizado o método de Penman (1956) (Ribeiro \& Villa Nova, 1979). Nesta região, a variação da temperatura média é menor, fazendo com que a evapotranspiração potencial esteja sempre acima dos $120 \mathrm{~mm}^{\mathrm{mês}}{ }^{-1}$. Estes resultados são diferentes dos obtidos para a bacia do Ji-Paraná. Nesta, a temperatura mensal média apresenta maior sazonalidade, com valores mais baixos (Figura 42 ), $1,5{ }^{\circ} \mathrm{C}$ na média, o que reduz a evapotranspiração potencial. Portanto, as diferenças encontradas entre os valores de Ribeiro \& Villa Nova e este estudo são esperadas e se devem ao fato de estes se referirem a localidades distintas.

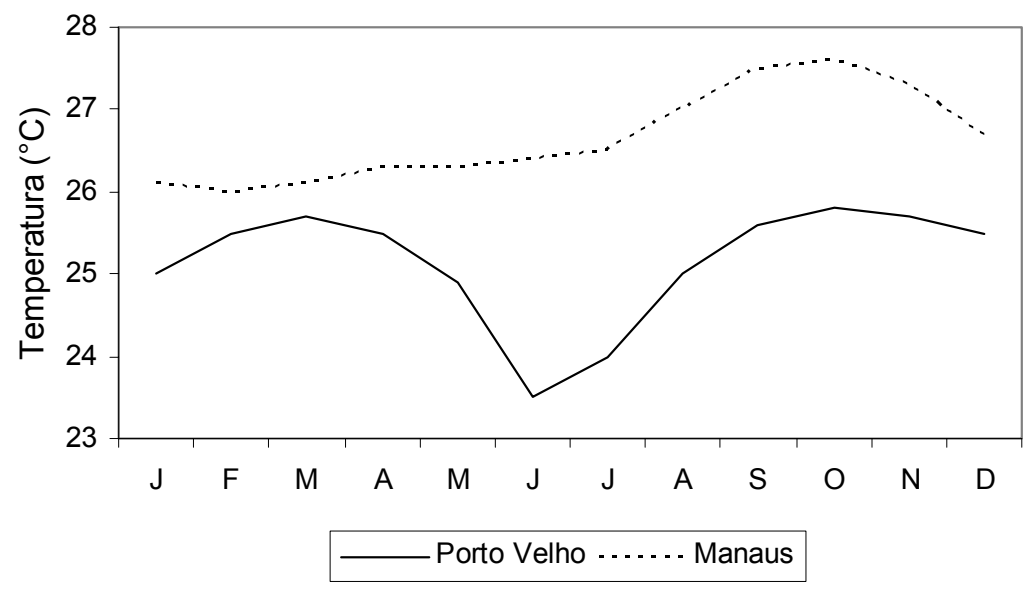

Figura 42 - Temperatura média normal (1961 - 1990) para Manaus e Porto Velho. (Fonte: INMET) 
A evapotranspiração real da bacia do Ji-Paraná foi de $1166 \mathrm{~mm}^{\text {ano }}{ }^{-1}$ (aprox. 3,2 $\left.\mathrm{mm} \mathrm{dia}{ }^{-1}\right)$, com máxima no início das chuvas no mês de outubro (131 mm em 1995 e $125 \mathrm{~mm}$ em 1996; aprox. 4,2 $\mathrm{mm} \mathrm{dia}^{-1}$ ) e mínima no auge da seca, julho e agosto (54 mm em agosto de 1995; aprox. 1,7 $\mathrm{mm} \mathrm{dia}^{-1}$ ). O pico na evapotranspiração real no início das chuvas e a reduzida evapotranspiração na seca indicam que o modelo utilizado é fortemente controlado pela água disponível, seja esta na forma de precipitação ou armazenada no solo.

Outros modelos e métodos estimaram a evapotranspiração real da Amazônia em torno de 3 a $5 \mathrm{~mm} \mathrm{dia}^{-1}$ (Leopoldo et al., 1982; Werth \& Avissar, 2004). No entanto, a sazonalidade da evapotranspiração depende muito da forma como esta é modelada (Werth \& Avissar, 2004). Willmott et al. (1985), utilizando medidas de estações climatológicas e a metodologia de balanço hídrico de Thornthwaite-Mather, estimaram a evapotranspiração da Amazônia variando de 3 a $5 \mathrm{~mm} \mathrm{dia}^{-1}$, média de $4 \mathrm{~mm} \mathrm{dia}{ }^{-1}$, com a máxima no período de Janeiro a Abril, coincidindo com o período de chuvas e indicando que a limitação da evapotranspiração é governada pela disponibilidade hídrica. Shuttleworth $^{2}$ calculou a evapotranspiração da região da Reserva Duke, próxima a Manaus, variando de 3 a $4 \mathrm{~mm} \mathrm{dia}{ }^{-1}$, com a máxima ocorrendo no equinócio de inverno. Isso mostra que o principal controlador da evapotranspiração neste modelo é a radiação incidente, máxima no inverno devido à baixa cobertura de nuvens. Já o controle efetuado pela vegetação é fraco (Werth \& Avissar, 2004). O modelo de circulação geral do Instituto de Estudos Espaciais de Goddard (GISS-GCM) calcula a evapotranspiração da região amazônica variando entre $3,5 \mathrm{~mm} \mathrm{dia}^{-1}$ no verão (época das chuvas) e 1,2 mm dia ${ }^{-}$ ${ }^{1}$ no final do inverno (setembro), quando o solo está mais seco (Werth \& Avissar, 2004). Este desencontro com o modelo de Shuttleworth se deve ao fato do modelo GISS-GCM apresentar um forte controle da evapotranspiração pela umidade do solo.

O excedente hídrico calculado para a bacia do Ji-paraná foi de $909 \mathrm{~mm}^{\mathrm{ano}}{ }^{-1}$, enquanto que o déficit foi de $239 \mathrm{~mm}^{\mathrm{ano}}{ }^{-1}$. A diferença de $32 \mathrm{~mm}$ encontrada entre a precipitação anual (2043 mm) e a evapotranspiração real mais o excedente hídrico (1166 mm mais $909 \mathrm{~mm}$, respectivamente) ocorre devido ao fato destes valores terem sido

\footnotetext{
2 citado por Werth \& Avissar, 2004
} 
calculados utilizando valores médios mensais. Além disso, existirem diferenças entre o armazenamento de água no início e fim do período estudado.

Os resultados do modelo também podem ser analisados de forma espacial, através das imagens de evapotranspiração potencial, real, déficit e excedente hídrico. Nestas, pode-se observar que a evapotranspiração só consegue ser máxima (potencial) caso haja água disponível (Figura 43), seja esta na forma de chuva ou armazenada no solo. Por outro lado, o déficit hídrico ocorre apenas nas áreas em que a evapotranspiração real foi inferior ao potencial. Outro aspecto que pode ser observado é a propagação dos dados de entrada (precipitação e CAD) aos resultados finais. Efeitos relativos aos artifícios da interpolação geoestatística podem ser mais facilmente observados nas épocas secas (Figura 44), quando a única fonte de água provém do armazenamento do solo. Como o armazenamento é fortemente influenciado pela CAD, as feições provenientes da interpolação geoestatística dos dados de textura do solo se propagam para o resultado final.

A partir destes dados pode-se concluir que o modelo de balanço hídrico de Thorthwaite - Matther, inserido no SIG, está funcionando temporalmente e espacialmente da forma esperada, sem grandes discrepâncias. 

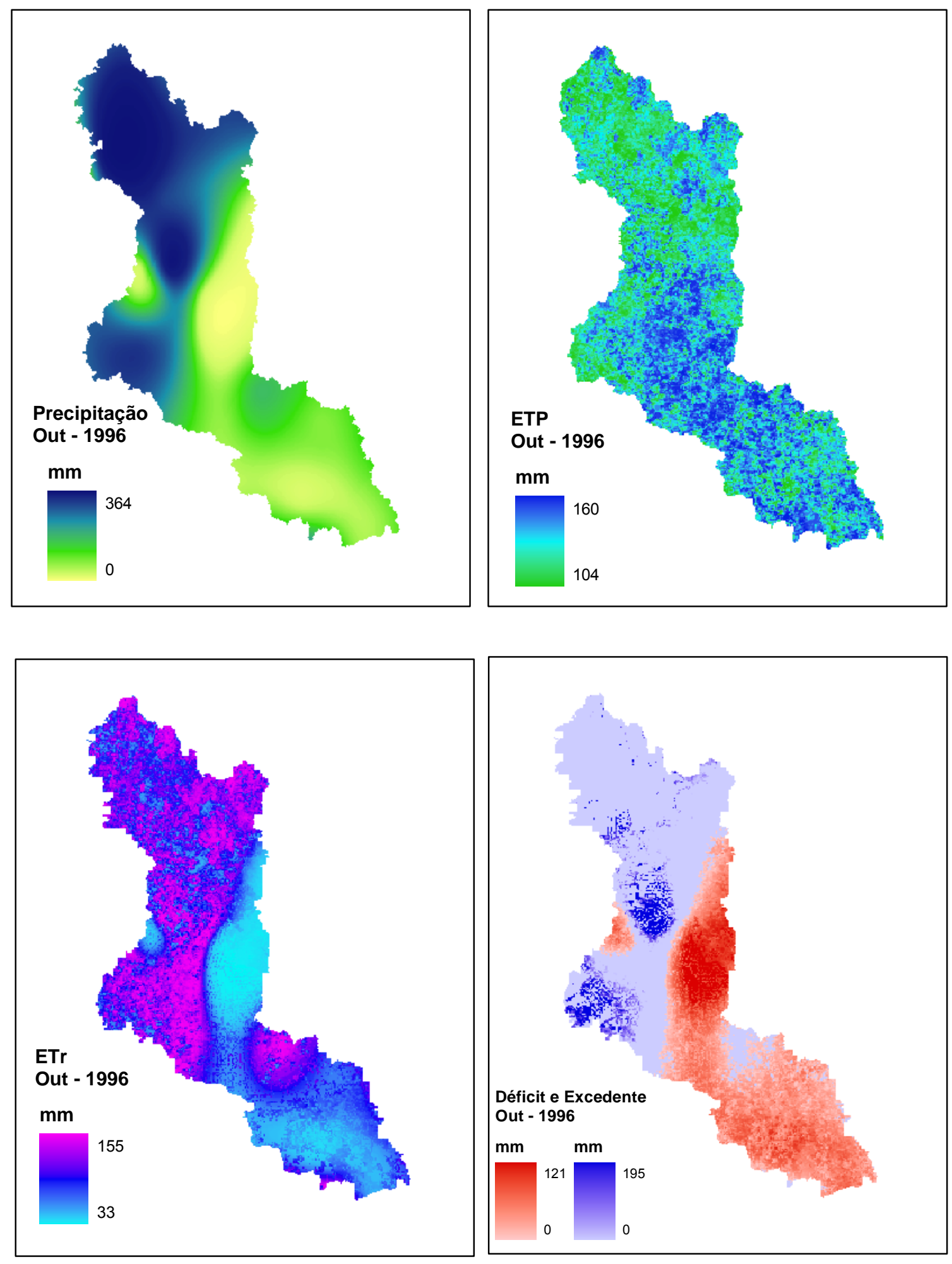

Figura 43 - Precipitação, Evapotranspiração Potencia (ETP), Evapotranspiração Real (ETr), Déficit e Excedente hídrico de outubro de 1996, modelados para a bacia do Ji-Paraná (RO) 

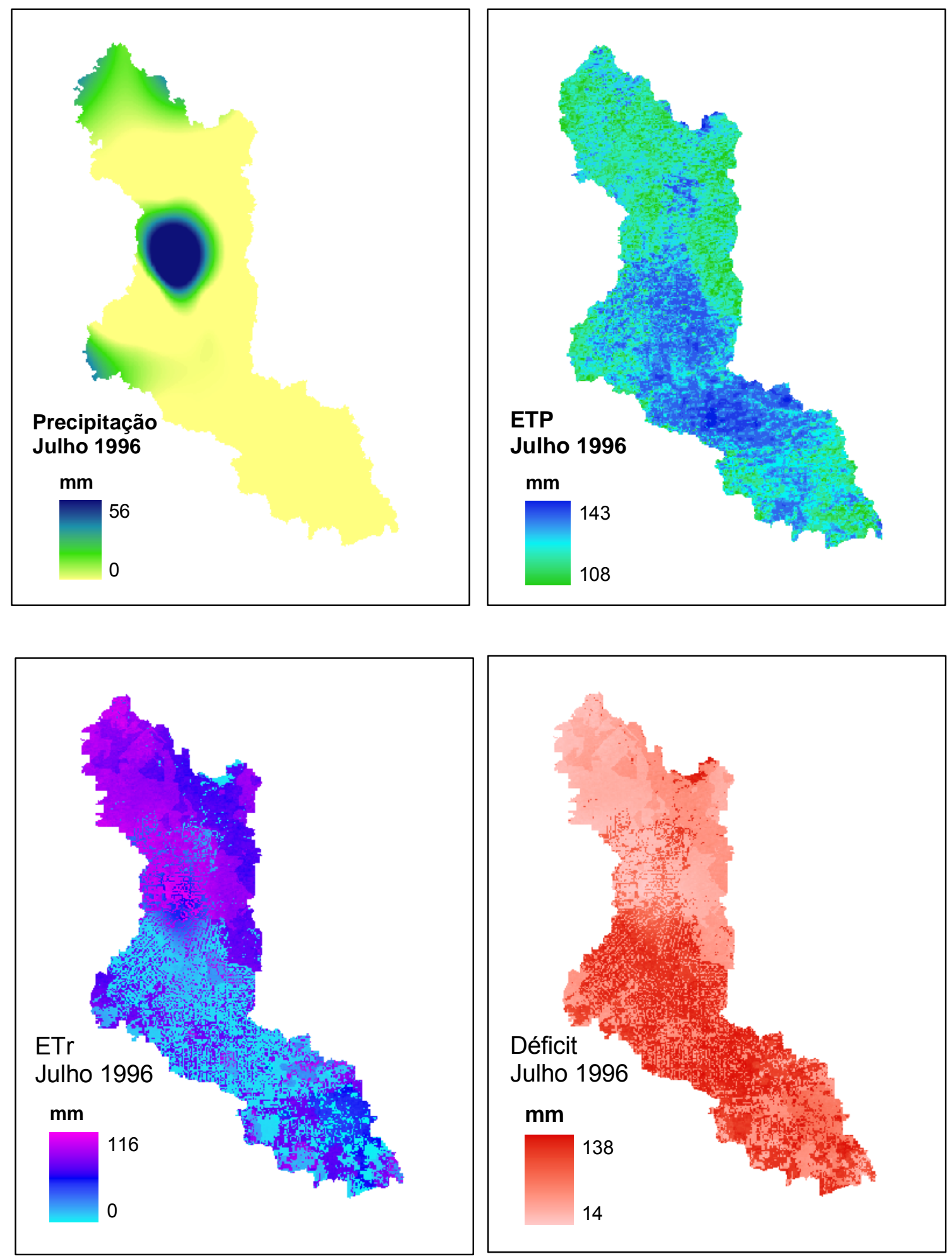

Figura 44 - Precipitação, Evapotranspiração Potencia (ETP), Evapotranspiração Real (ETr) e Déficit hídrico de julho de 1996, modelados para a bacia do Ji-Paraná (RO) 
Os balanços hídricos para as 10 sub-bacias, obtido pelo modelo, mostram que todas apresentam a mesma sazonalidade (Figura 45, 46, 47 e 48). As sub-bacias Mineração Jacunda (Figura 46a) e Piratininga (Figura 47b) apresentam um menor déficit hídrico ao longo do ano (diferença entre ETP e ETr), justamente por estas serem as duas sub-bacias com as maiores capacidades de armazenamento de água (CAD).

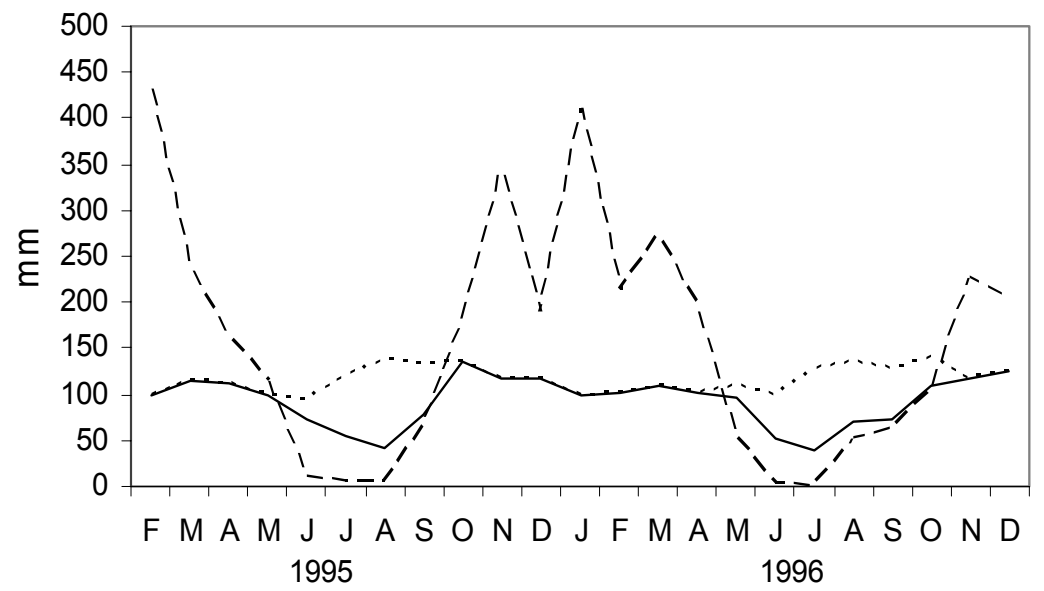

a)

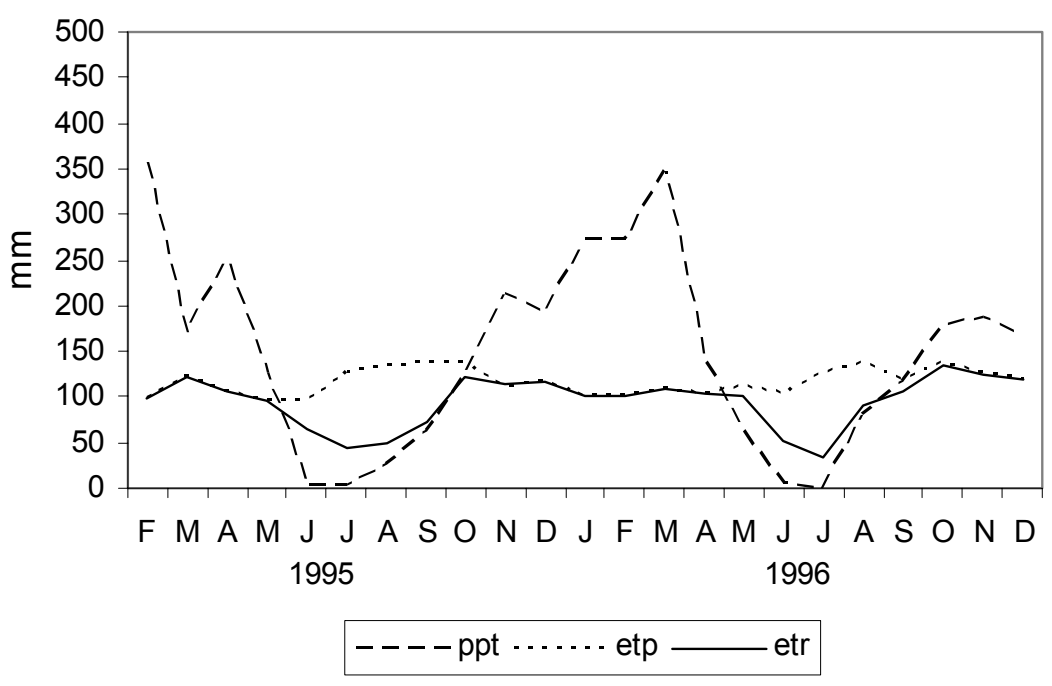

Figura 45 - Balanço hídrico modelado para as sub-bacias a) Cachoeira Primavera e b) Jaru de fevereiro de 1995 a dezembro de 1996. PPT = precipitação; ETP = Evapotranspiração potencial; ETr $=$ Evapotranspiração real 


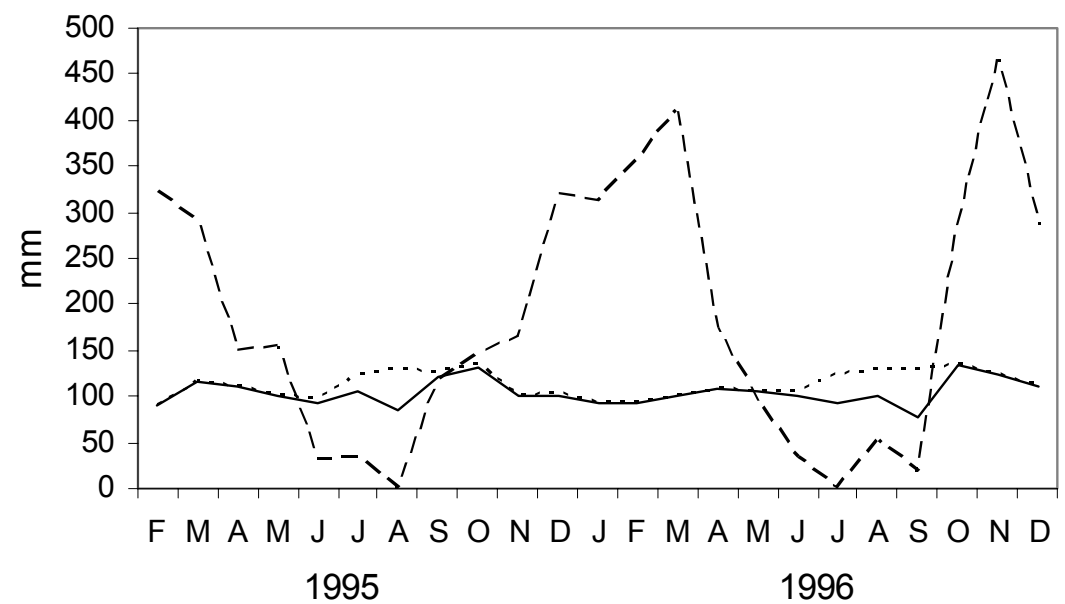

a)

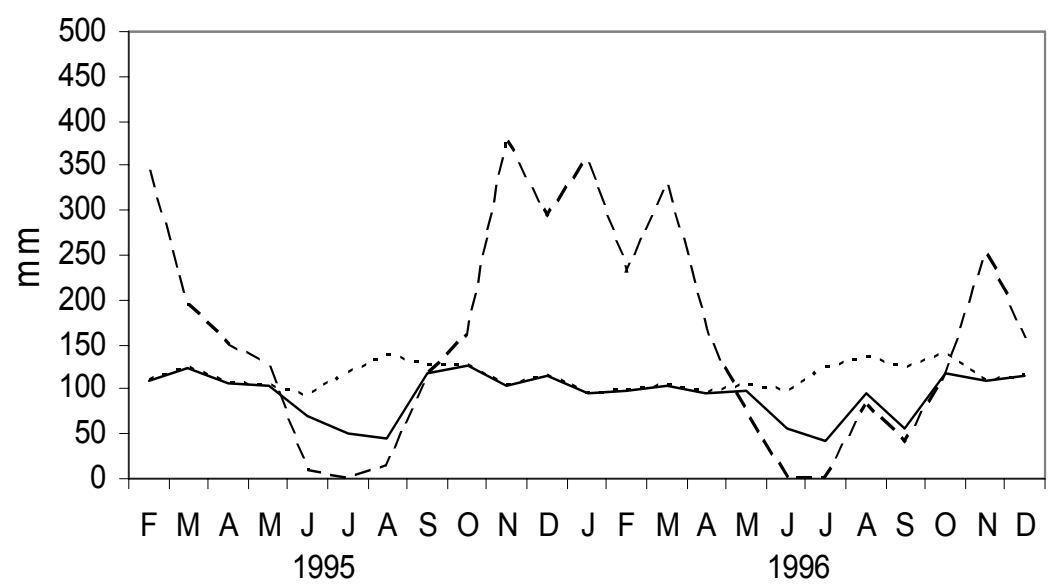

b)

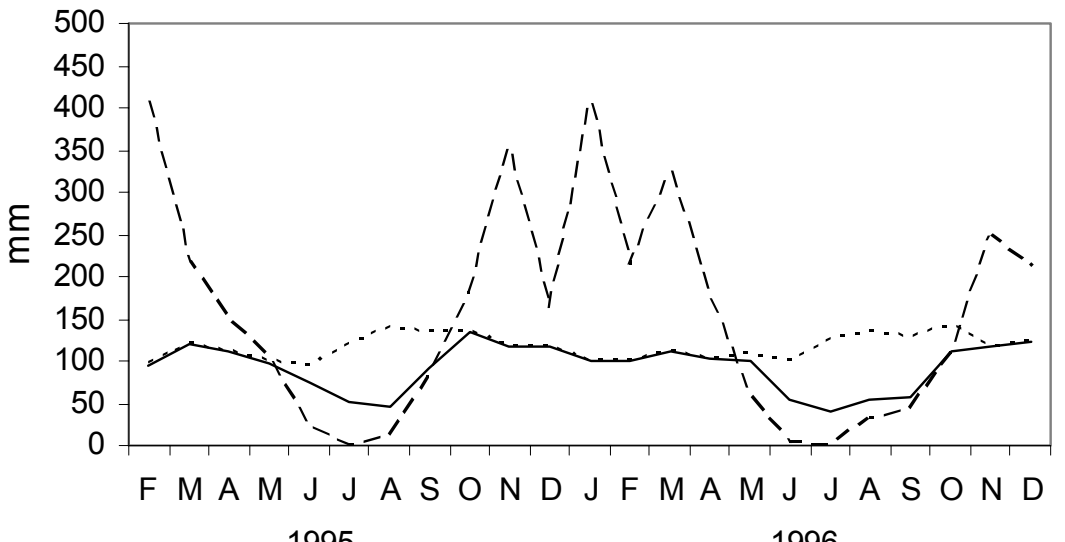

c)

$$
\text { - - - - ppt ..... - etp — etr }
$$

Figura 46 - Balanço hídrico modelado para as sub-bacias a) Mineração Jacunda, b) Flor do Campo e c) Expansão de fevereiro de 1995 a dezembro de 1996. PPT = precipitação; ETP = Evapotranspiração potencial; $\mathrm{ETr}$ = Evapotranspiração real 


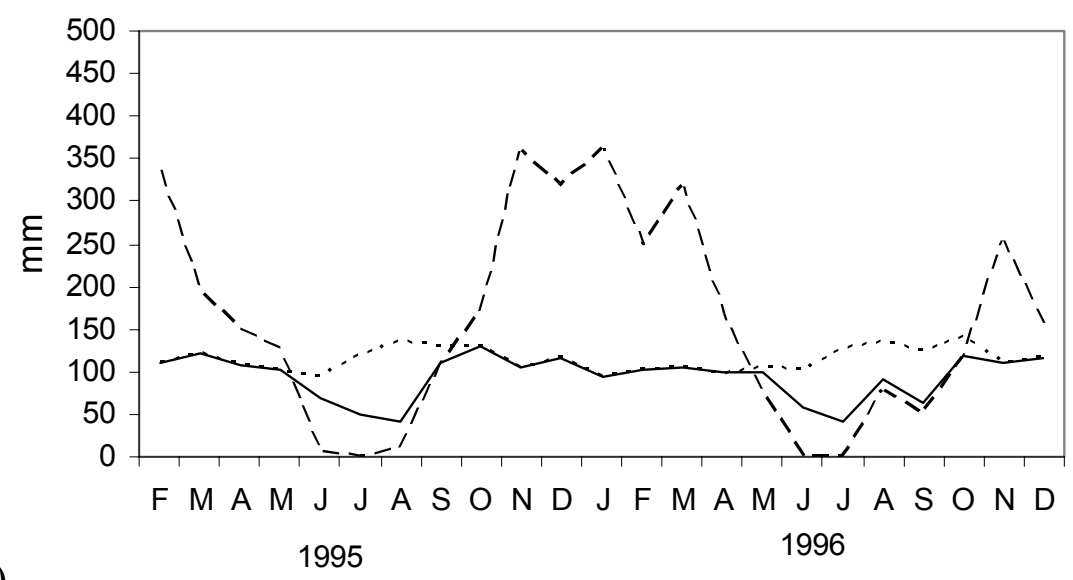

a)

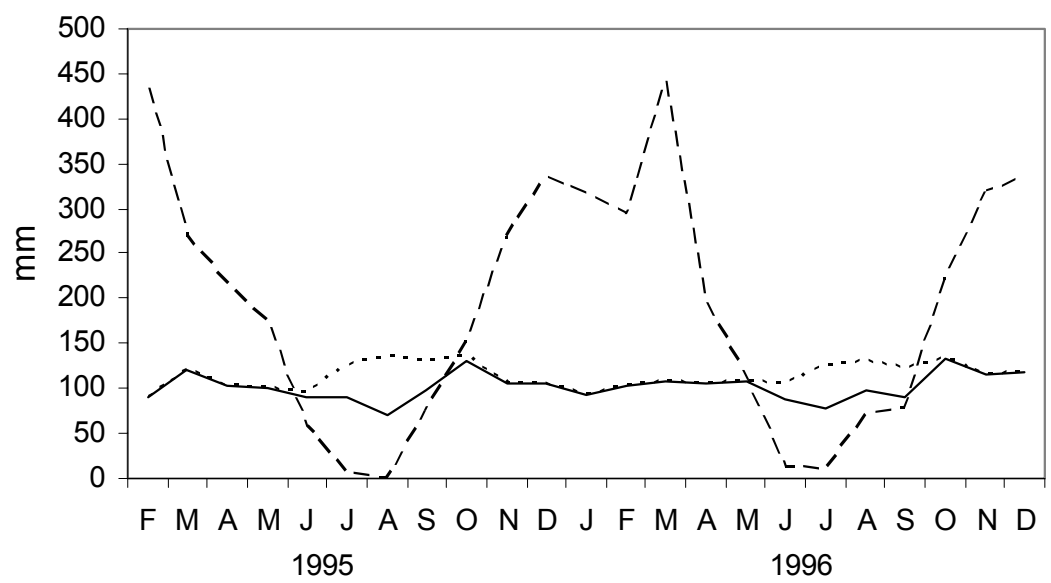

b)

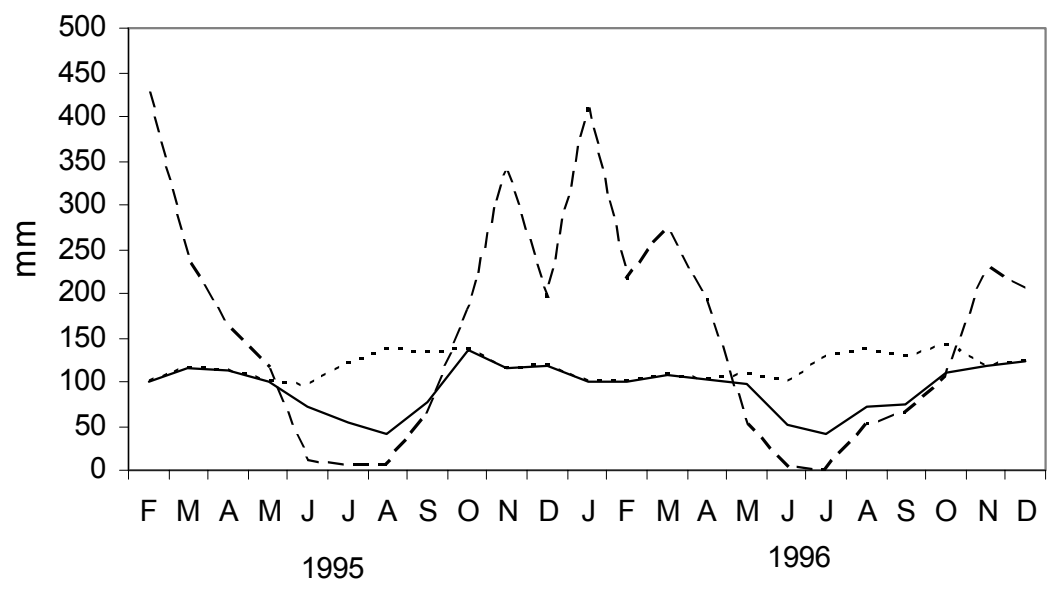

c)

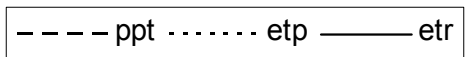

Figura 47 - Balanço hídrico modelado para as sub-bacias a) Comemoração, b) Piratininga e c) Pimenta Bueno de fevereiro de 1995 a dezembro de 1996. PPT = Precipitação ETP = Evapotranspiração potencial; ETr = Evapotranspiração real 


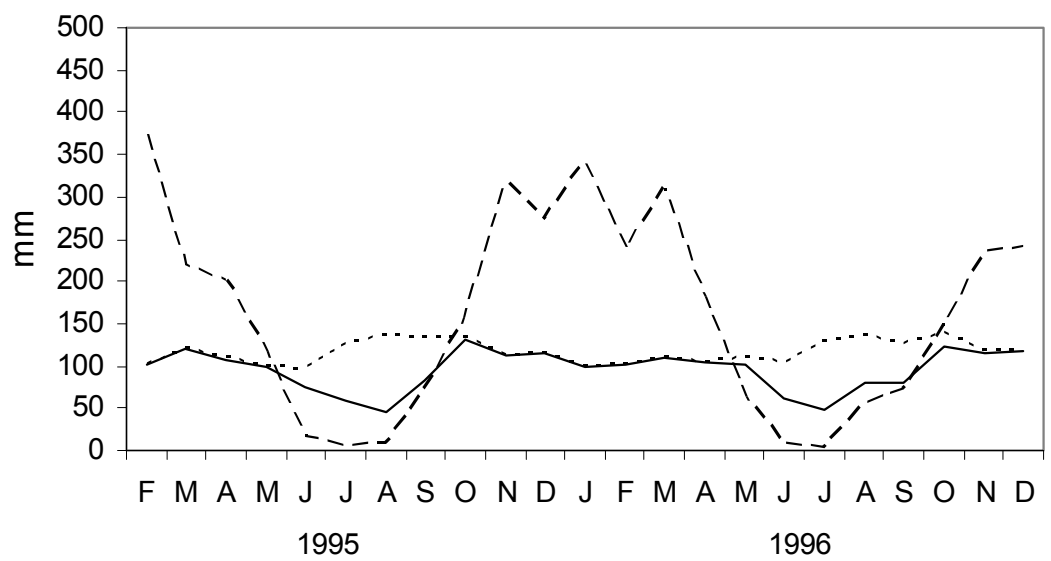

a)

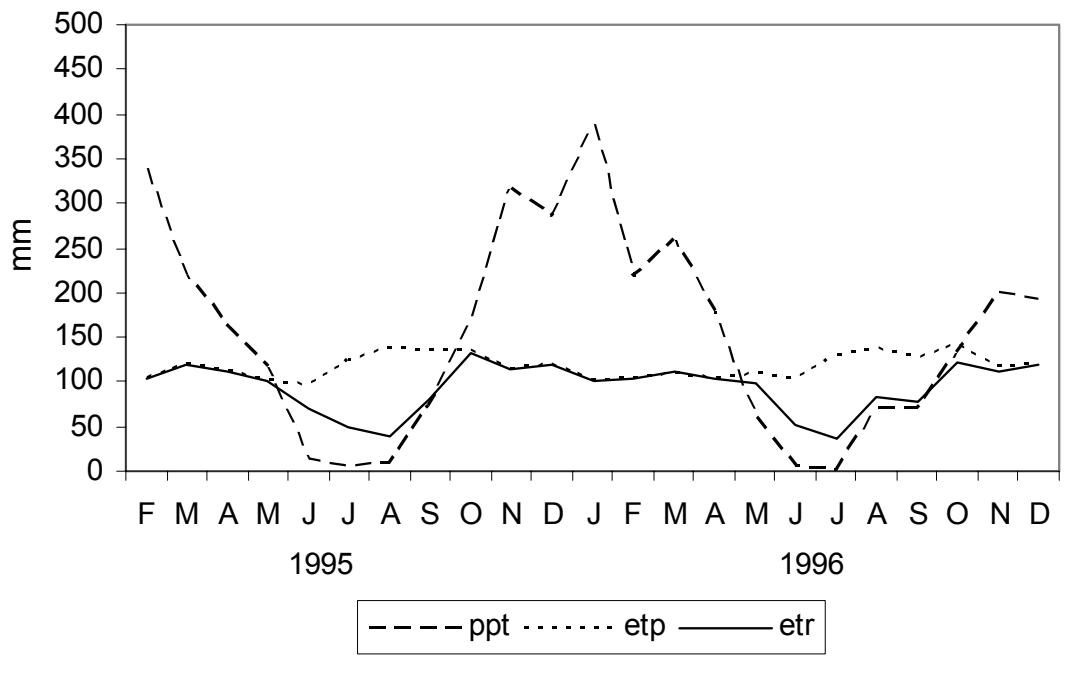

Figura 48 - Balanço hídrico modelado para a sub-bacia a) Tabajara e b) Ji-Paraná de fevereiro de 1995 a dezembro de 1996. $\mathrm{PPT}=$ precipitação; $\mathrm{ETP}=$ Evapotranspiração potencial; $\mathrm{ETr}=$ Evapotranspiração real

O balaço hídrico das 10-sub-bacias foi utilizado na comparação do excedente hídrico modelado com a descarga de cada sub-bacia e a evapotranspiração real modelada com a evapotranspiração anual calculada pelo balanço de massa, de modo a avaliar o funcionamento do modelo (Tabela 9). 
Tabela 9. Evapotranspiração real e excedente hídrico para as 10 sub-bacias, comparando valores modelados e medidos $($ razão $=$ modelado $/$ medido $)$

\begin{tabular}{ccccccc}
\hline & \multicolumn{3}{c}{ Etr $(\mathrm{mm}$ ano-1) } & \multicolumn{3}{c}{ Excedente (mm ano-1) } \\
Sub-Bacia & Modelada & Medida & razão & Modelado & Medido & razão \\
\hline Mineiração Jacunda & 1249,1 & 1461,4 & 0,85 & 941,1 & 719,1 & 1,31 \\
Faz. Expansão & 1119,8 & 1320,4 & 0,85 & 890,6 & 678,0 & 1,31 \\
Jaru & 1114,9 & 953,1 & 1,17 & 671,7 & 815,7 & 0,82 \\
Faz. Flor do Campo & 1152,0 & 1377,3 & 0,84 & 1032,7 & 810,2 & 1,27 \\
Piratininga & 1224,6 & 1412,5 & 0,87 & 1057,3 & 867,8 & 1,22 \\
Comemoração & 1150,9 & 1356,9 & 0,85 & 1048,4 & 844,4 & 1,24 \\
Cachoeira Primavera & 1119,0 & 1183,5 & 0,95 & 863,9 & 791,7 & 1,09 \\
Pimenta Bueno & 1117,6 & 1232,9 & 0,91 & 868,2 & 745,5 & 1,16 \\
Ji-Paraná & 1133,2 & 1221,9 & 0,93 & 896,8 & 796,8 & 1,13 \\
Tabajara & 1146,7 & 1217,5 & 0,94 & 903,7 & 806,6 & 1,12 \\
\hline
\end{tabular}

A média da evapotranspiração real modelada para as 10 sub-bacias foi de 1152,8 $\mathrm{mm}$, enquanto a obtida pelo balanço de massa foi de $1273,7 \mathrm{~mm}$. A média do excedente modelado foi de $917,5 \mathrm{~mm}$ e a calculada pelo balanço de massa de 787,6 $\mathrm{mm}$. Pode-se observar que o modelo utilizado subestima, na média, $9 \%$ a evapotranspiração real da bacia e superstima a vazão em 17 \%. A diferença entre o erro na evapotranspiração real e a vazão pode ser devida a diversos fatores. O mais provável está no fato da precipitação utilizada no cálculo do balanço de massa ser a mesma usada no modelo, fazendo com que os dados modelados e os utilizados para a verificação do resultado estejam relacionados. O mesmo não ocorre quando a verificação é efetuada utilizando-se os dados de vazão das sub-bacias, pois estes não apresentam relação com o excedente modelado.

A regressão entre a evapotranspiração real modelada e a calculada pelo balanço de massa para as 10 sub-bacias mostrou-se significativa a $95 \%$ de confiança, com $\mathrm{r}^{2}$ igual a 0,5 (Figura 49). É importante salientar que dentre as 10 sub-bacias estudadas, apenas 5 são espacialmente independentes, ou seja, sem ligação entre elas (Jacunda, Piratininga, Jaru, Cachoeira Primavera e Flor do Campo). A mesma regressão apresentada na Figura 49, quando efetuada apenas com as bacias independentes, ainda é significativa a $95 \%$ de confiança, com $r^{2}$ igual a 0,68 . 


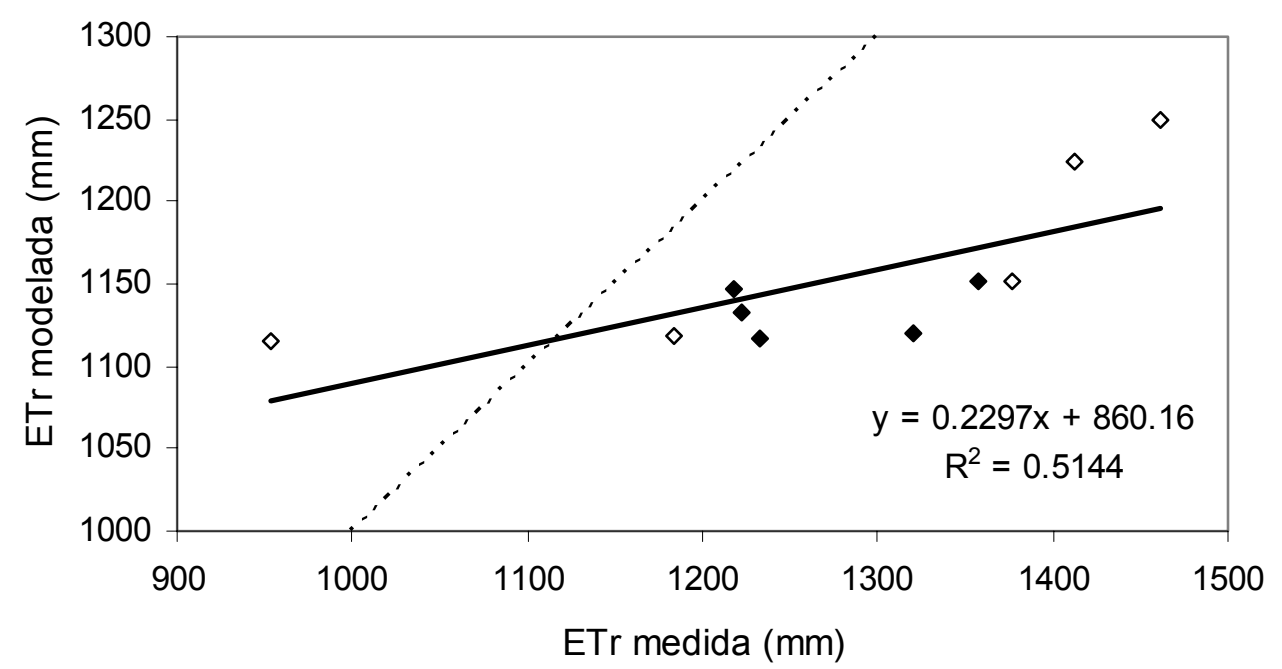

Figura 49 - Evapotranspiração real modelada vs. medida por balanço de massa para as 10 sub-bacias do JiParaná. Símbolos vazios indicam sub-bacias independentes. Linha pontilhada representa relação 1:1

A regressão entre o excedente modelado e a descarga das 10 sub-bacias (Figura 50) também mostrou-se significativa a $95 \%$ de confiança, porém com $r^{2}$ reduzido, igual a 0,08 . A regressão utilizando apenas as sub-bacias independentes não foi significativa.

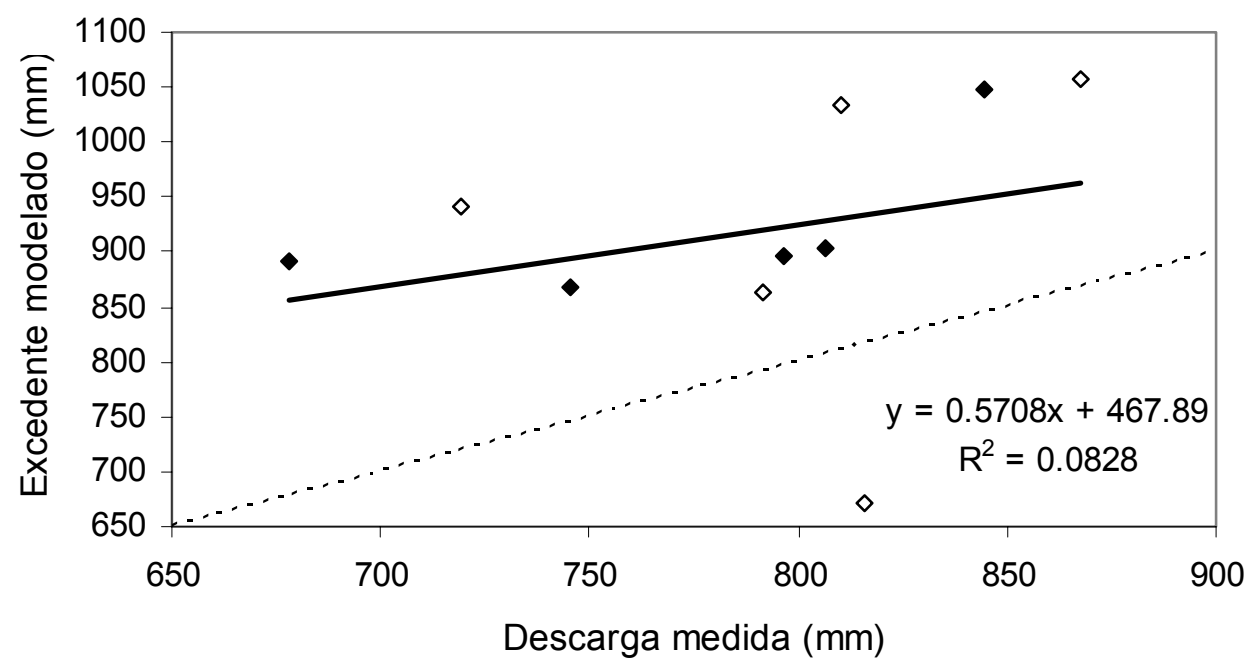

Figura 50 - Excedente hídrico modelado vs. descarga observada para as 10 sub-bacias do Ji-Paraná. Símbolos vazios indicam as sub-bacias independentes. Linha pontilhada representa relação 1:1 
Verifica-se que, na Figura 49, a maioria dos pontos se encontra abaxio da reta 1:1 (pontilhada), mostrando que o modelo esta subestimando a evapotranspiração real. Já na Figura 50, a maioria dos pontos estão acima da reta 1:1, indicando superestimativa do excedente hídrico. Porém, ambas figuras, contém um ponto que se difere dos demais, indicando superestimativa da evapotranspiração real e subestimativa do excedente hídrico. Este ponto discrepante representa a sub-bacia Jaru, com $61 \%$ de sua área desmatada, a maior dentre as sub-bacias, resultando na sub-bacia com a menor CAD $(197 \mathrm{~mm})$. Isso indica que a profundidade de raízes de pastagem utilizada no modelo pode estar muito elevada. Enquanto que a profundidade de raízes de pastagem utilizada no modelo foi de $70 \mathrm{~cm}$, Pagoto (2001) concluiu que $76 \%$ das raízes vivas de pasto Tanzânia (Panicum maximum, Jacq.) são encontradas nos primeiros $20 \mathrm{~cm}$ de solo. Portanto, a CAD das áreas de pastagem podem estar muito elevadas, fazendo com que a evapotranspiração real seja superestimada e o excedente, subestimado. Porém, outras sub-bacias com elevado grau de desmatamento, como Ji-Paraná (57 \%) e Fazenda Expansão (55 \%), não apresentam tal comportamento, indicando que pode haver algum outro fator que esteja influenciando o resultado da sub-bacia Jaru.

Em relação aos métodos de comparação dos erros (razão entre modelado e medido), nota-se que ambos erros estão relacionados. À medida que se diminui o erro na estimativa do excedente, diminui-se o erro na estimativa da evapotranspiração (Figura 51). Isto ocorre porque os parâmetros utilizados na verificação são dependentes. Uma maior vazão implica em uma menor evapotranspiração calculada pelo balanço de massa, ou seja, quanto maior a superestimativa da vazão, mais subestimada estará a evapotranspiração real. Mais uma vez pode-se notar um ponto discrepante na figura, representando a sub-bacia Jaru. 


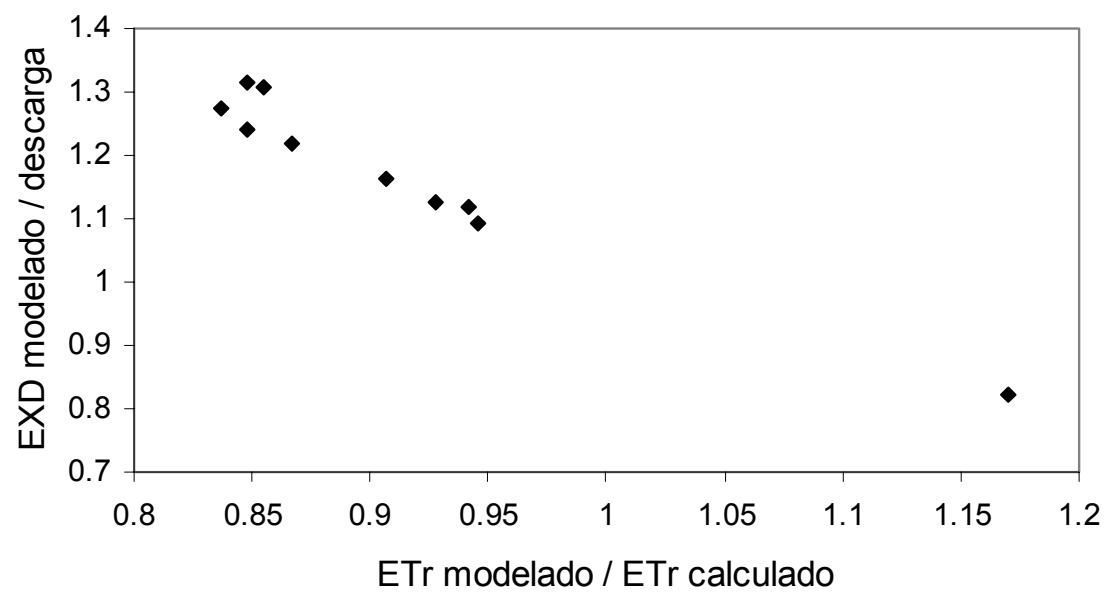

Figura 51 - Relação entre o erro da estimativa do excedente hídrico com a estimativa da evapotranspiração real

Os valores modelados e os respectivos erros não apresentam relação com a área de cada sub-bacia (Figura 52). Também não existe grande tendência de mudança dos erros em relação a CAD média de cada sub-bacia (Figura 53).

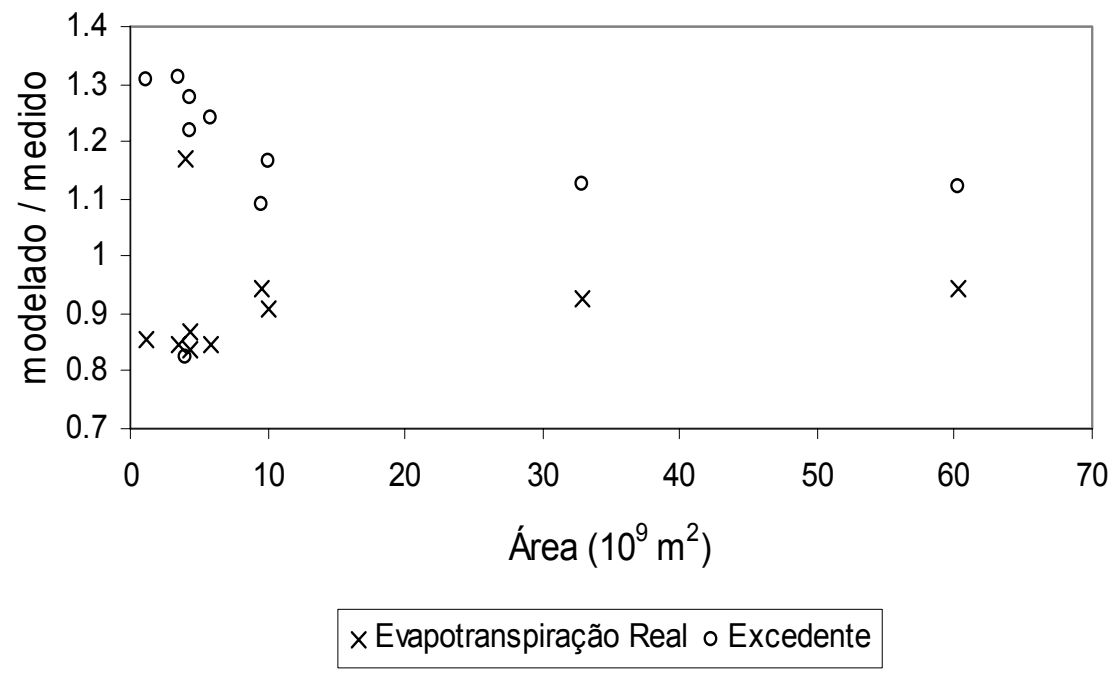

Figura 52 - Erros estimados do excedente hídrico e da evapotranspiração real modelada em relação à área da sub-bacia 


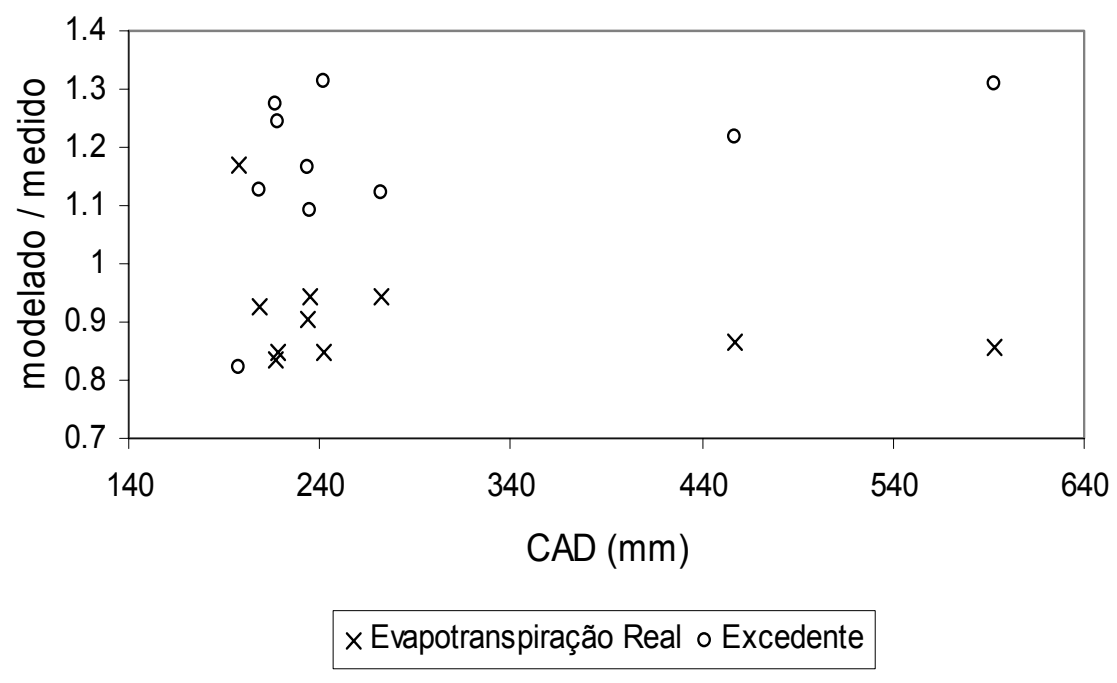

Figura 53 - Erros estimados do excedente hídrico e da evapotranspiração real modelada em relação à CAD média da sub-bacia

Os erros observados nas figuras anteriores indicam um excesso de água que se transforma em escoamento, superestimando a vazão e subestimando a evapotranspiração. Algumas das possíveis fontes destes erros são:

a) Excesso na entrada de água: caso a interpolação dos dados pluviométricos tenha resultado em uma superestimativa da precipitação sobre a bacia, o efeito observado no modelo seria um maior excedente hídrico. No entanto, este não parece ser o caso, uma vez que as precipitações para as diferentes estações e a média interpolada são inferiores à normal climatológica, conforme visto nas figuras de precipitação acumulada (Figura 16).

b) Subestimativa da evapotranspiração potencial: Whright et al. (1996), medindo o balanço de energia em dois locais em Rondônia de abril a julho de 1993, constataram que a energia disponível para a evapotranspiração se encontrava, na maior parte das vezes, acima de $4 \mathrm{~mm} \mathrm{dia}^{-1}$, superior aos 3,8 $\mathrm{mm} \mathrm{dia}^{-1}$ obtidos pelo modelo utilizado neste estudo. No entanto, neste mesmo trabalho, medidas de evaporação para pasto e floresta se mantém em torno de 3 a $4 \mathrm{~mm} \mathrm{dia}^{-1}$, próximas aos valores de evapotranspiração real modelados. 
c) Subestimativa da CAD: Uma CAD muito reduzida implica em menor armazenamento de água, o que resulta em maior déficit hídrico $\mathrm{e}$ evapotranspiração real subestimada. Ao mesmo tempo, uma CAD menor implica em uma menor quantidade de água armazenada no solo. Com isso, logo no início da estação chuvosa, o armazenamento atinge o máximo, gerando excedente hídrico mais cedo, superestimando o excedente hídrico total. Portanto, os erros encontrados podem ser devido a uma estimativa errada da CAD. No caso da sub-bacia Jaru, onde se tem uma superestimativa da evapotranspiração e subestimativa do excedente, provavelmente ocorre o contrário, ou seja, a CAD esta superdimensionada. Esta bacia difere das outras por apresentar uma grande área desmatada (61\%), o que nos leva a concluir que a profundidade de raiz de $0,7 \mathrm{~m}$, utilizada para as pastagens é muito elevada, superdimensionando a CAD.

Portanto, o erro mais provável é a subestimativa da CAD. No modelo utilizado, convencionou-se que as raízes das florestas atingem $4 \mathrm{~m}$ de profundidade. No entanto, estudos realizados na região leste da Amazônia (Paragominas, PA) mostraram que árvores da floresta podem retirar água de até $8 \mathrm{~m}$ de profundidade (Nepstad, 1994). Além disso, o fato da evapotranspiração real da floresta na região de Ji-Paraná não apresentar redução com o declínio da umidade dos primeiros 3,6 $\mathrm{m}$ de solo, indica que a mesma retira água de camadas mais profundas de solo. $\mathrm{O}$ aumento da profundidade de raízes da floresta pode elevar a evapotranspiração real na estiagem, além de retardar a geração de excedente hídrico no início das chuvas, reduzindo o excedente hídrico total. Enquanto que o modelo aqui utilizado apresenta uma CAD média de $325 \mathrm{~mm}$, com máximo de $640 \mathrm{~mm}$, alguns modelos utilizam valores bem maiores, como o GCM do Goddard Earth Observing System, com armazenamento de 1600 mm (Werth \& Avissar, 2004). Já para as pastagens, conforme visto na sub-bacia Jaru, há necessidade de redução da profundidade de raízes, elevando o déficit hídrico, reduzindo a evapotranspiração e aumentando o excedente hídrico, uma vez que este é gerado mais cedo. 


\subsection{Efeito do desmatamento}

A remoção da cobertura nativa afeta o ciclo hidrológico de diversas maneiras, alterando a interceptação das chuvas, a velocidade de infiltração de água no solo, modificando o escoamento superficial e a evapotranspiração (Bruijnzeel, 1996), além de alterar o balanço de energia da superfície (Culf et al., 1996; Lyra et al., 1997).

No presente modelo, o efeito do desmatamento foi simulado através da alteração na profundidade das raízes, que altera o cálculo da CAD. Não existe nenhum mecanismo para simular a alteração no balanço de energia acarretado pelo desmatamento, pois este não é necessário, uma vez que o balanço energético afetaria a temperatura da superfície, a qual é medida a partir de imagens de sensores orbitais.

Para estudar o efeito do desmatamento, e mais precisamente o efeito da CAD, o modelo foi executado com três diferentes cenários: 1) considerando-se que toda a bacia esta coberta por pastagens (profundidade radicular de $0,7 \mathrm{~m}$ ); 2 ) toda a bacia esta coberta por florestas (profundidade de raízes de $2 \mathrm{~m}$ ) e 3 ) com toda a bacia coberta por florestas com profundidade radicular de $5 \mathrm{~m}$.

No primeiro cenário, apenas com pastagens, a CAD média foi de $81 \mathrm{~mm}$, com mínimo de $42 \mathrm{~mm}$ e máximo de $112 \mathrm{~mm}$. Já para a floresta com raízes de $2 \mathrm{~m}$ de profundidade (segundo cenário), a CAD média foi de $233 \mathrm{~mm}$, variando entre 120 e 320 mm. No último cenário, a CAD variou de 300 a $800 \mathrm{~mm}$, com média de $582 \mathrm{~mm}$.

Mudanças na CAD alteram a quantidade de água disponível para a evapotranspiração, sendo que quanto mais água disponível, mais a evapotranspiração real se mantém próxima da potencial nos períodos em que não se tem entrada de água pela precipitação (Figura 54), aumentando a evapotranspiração real da bacia como um todo. No primeiro cenário, com a bacia completamente coberta por pastagens, a evapotranspiração real foi de $1070 \mathrm{~mm}$ ano ${ }^{-1}$. Para o segundo cenário, com a bacia recoberta por florestas com profundidade radicular de $2 \mathrm{~m}$, a evapotranspiração real foi de $1172 \mathrm{~mm} \mathrm{ano}^{-1}$. Já no terceiro cenário, com raízes com $5 \mathrm{~m}$ de profundidade, a evapotranspiração real da bacia foi de $1267 \mathrm{~mm} \mathrm{ano}^{-1}$. 


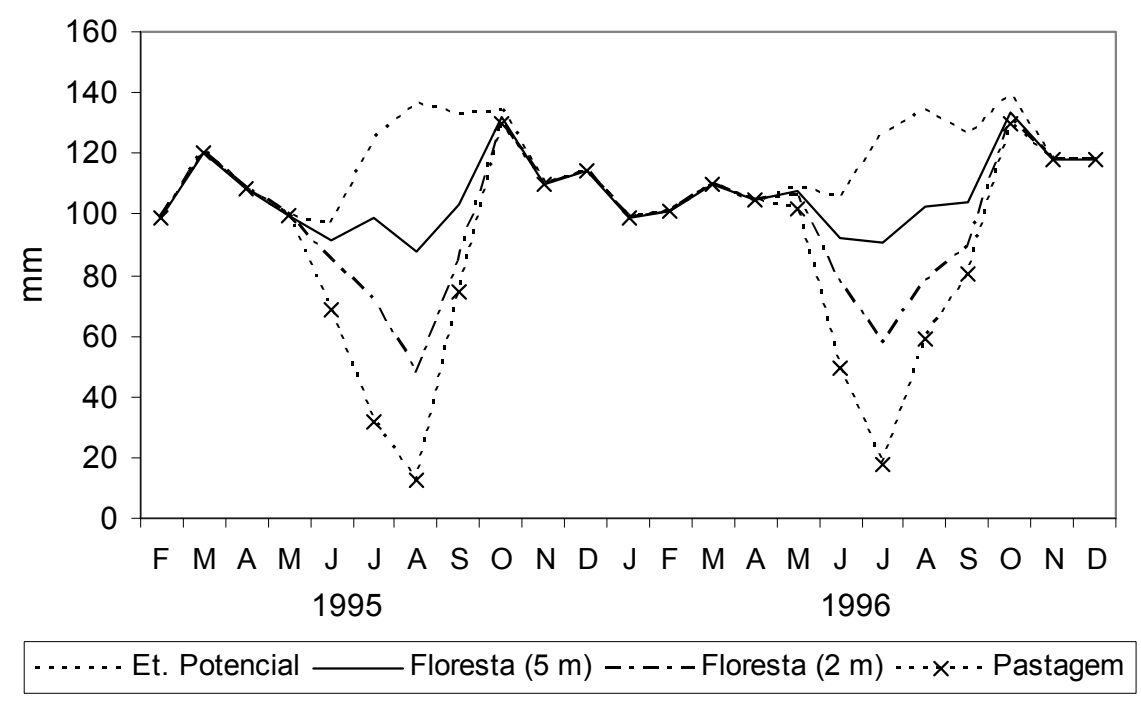

Figura 54 - Evapotranspiração real média da bacia do Ji-Paraná para diferentes cenários e evapotranspiração potencial

O déficit hídrico também é afetado, sendo que este é reduzido com o aumento da CAD, além de demorar mais para se formar (Figura 55). O déficit hídrico total com a bacia coberta por pastagens foi de $334 \mathrm{~mm} \mathrm{ano}^{-1}$. Já nos cenários em que a bacia apresenta apenas cobertura florestal, o déficit diminui para $228 \mathrm{~mm}^{-1}$ e $125 \mathrm{~mm}$ ano${ }^{1}$, para profundidade radicular de 2 e $5 \mathrm{~m}$, respectivamente.

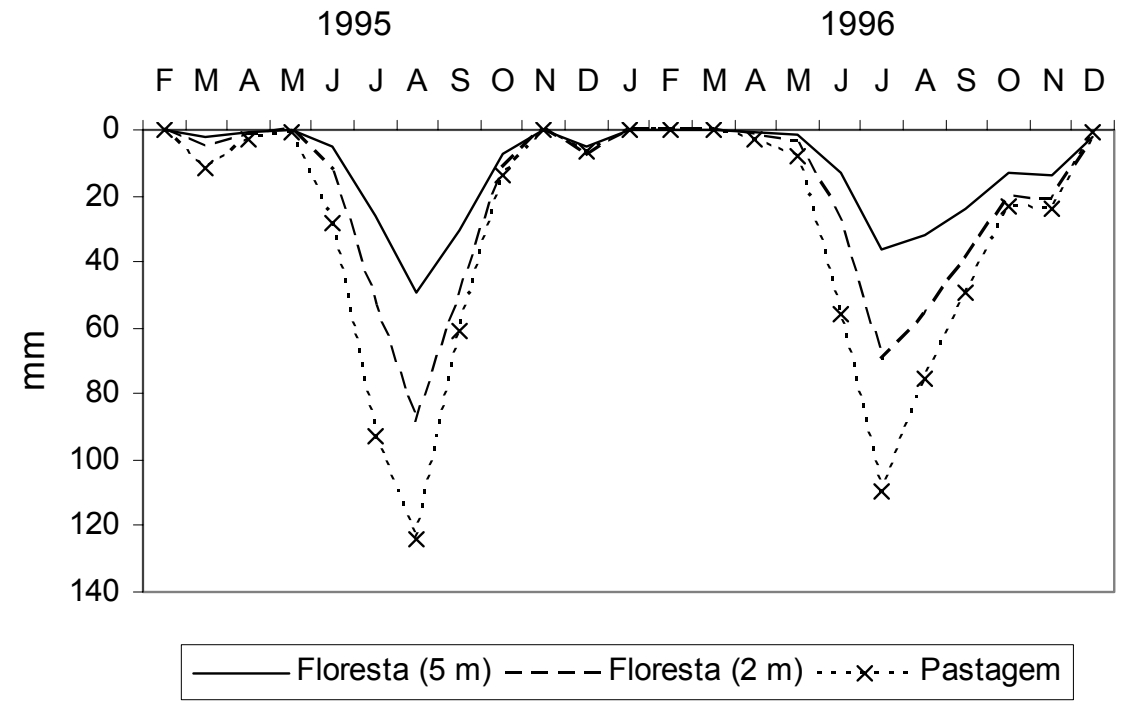

Figura 55 - Déficit hídrico médio da bacia do Ji-Paraná para diferentes cenários 
O excedente hídrico também é afetado, demorando mais tempo para ser gerado, pois este só ocorre após a saturação do armazenamento do solo (Figura 56). O excedente hídrico para a bacia com pastagens foi de $986 \mathrm{~mm} \mathrm{ano}^{-1}$ enquanto que para a floresta foi de $883 \mathrm{~mm}^{-1}$ e $789 \mathrm{~mm}^{-1} \mathrm{ano}^{-1}$, com profundidades de 2 e $5 \mathrm{~m}$, respectivamente.

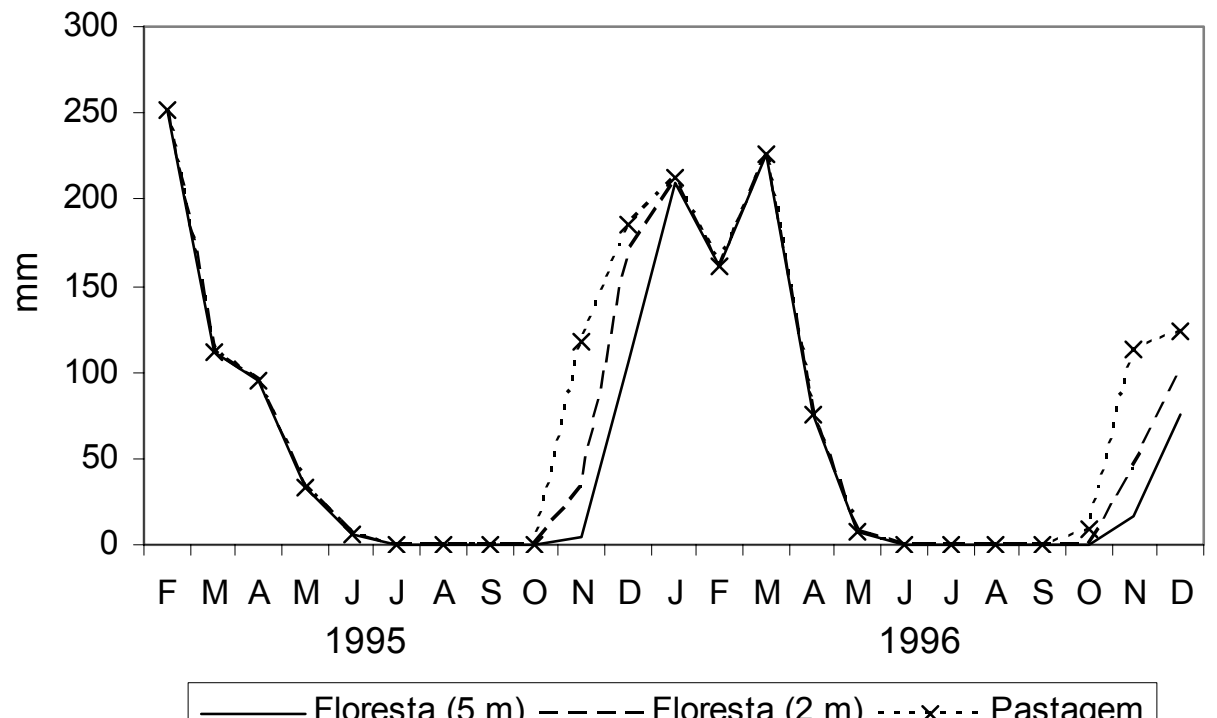

Figura 56 - Excedente hídrico médio da bacia do Ji-Paraná para diferentes cenários

Portanto, a redução da $\mathrm{CAD}$, simulando a remoção da floresta, resultou na diminuição da evapotranspiração potencial, no aumento do excedente e déficit hídrico e aumento do período em que a bacia apresenta déficit. Em uma extensa revisão, Bosh \& Hewlett (1982) mostraram que o desmatamento de pequenas bacias hidrográficas (cerca de $1 \mathrm{~km}^{2}$ ) tem como conseqüência um aumento na descarga destas, devido principalmente a redução da evapotranspiração. Através do estudo de séries históricas de vazão e precipitação, o mesmo efeito também foi observado na bacia de Porto Nacional, TO, com aproximadamente $175,000 \mathrm{~km}^{2}$ (Costa et al., 2003). A redução da evapotranspiração devido à remoção da floresta também foi observada por um modelo complexo que considera a interação biosfera-atmosfera. No entanto, a vazão simulada foi menor após a retirada da floresta. Isso porque, de acordo com o modelo, a remoção da floresta reduziu as chuvas, afetando a descarga (Shukla et al., 1990). 
$\mathrm{O}$ aumento do excedente hídrico da bacia em aproximadamente $100 \mathrm{~mm}$ ano ${ }^{-1}$, quando esta foi completamente coberta por pastagens, indica um aumento da descarga anual do rio Ji-Paraná de 7,54 x $10^{9} \mathrm{~m}^{3}$ ano ${ }^{-1}$. Considerando que este aumento ocorre no período em que o armazenamento do solo esta sendo recarregado (outubro a janeiro Figura 56), isto significa que nestes 4 meses, a vazão aumentaria em aproximadamente $730 \mathrm{~m}^{3} \mathrm{~s}^{-1}$. Este aumento representa mais da metade da vazão média destes quatro meses, que é de $1083 \mathrm{~m}^{3} \mathrm{~s}^{-1}$. Significa também um aumento duas vezes maior que a vazão média do mês com a menor vazão (setembro, $314 \mathrm{~m}^{3} \mathrm{~s}^{-1}$ ).

Tanto a evapotranspiração real e o excedente hídrico modelado no terceiro cenário (1267 mm ano ${ }^{-1}$ e $789 \mathrm{~mm} \mathrm{ano}^{-1}$, respectivamente) estão muito próximos dos valores médios calculados pelo balanço de massa das sub-bacias $\left(1222,42 \mathrm{~mm}^{2} \mathrm{ano}^{-1} \mathrm{e}\right.$ $795,59 \mathrm{~mm}$ ano ${ }^{-1}$ ), indicando que as diferenças encontradas entre o balanço hídrico modelado e o calculado para as 10 sub-bacias são devidas a sub-estimativa da evapotranspiração real na época seca, atribuídas ao reduzido armazenamento de água no solo. 


\section{CONCLUSÕES}

A partir dos dados de precipitação e descarga das sub-bacias do Ji-Paraná, já é possível detectar influência do desmatamento no ciclo hidrológico, sem o uso de modelos. Bacias mais desmatadas apresentaram maior descarga em relação à precipitação.

A correção atmosférica das imagens do sensor AVHRR é importante na obtenção das imagens de temperatura da superfície. A utilização de produtos prontos do sensor orbital MODIS pode facilitar esta etapa do trabalho, uma vez que já estão disponíveis compostas mensais de temperatura, sem a influência de nuvens e com a correção atmosférica já aplicada.

Artifícios de interpolação se propagam pelo modelo até o resultado final. Estudos comparativos entre diferentes métodos de interpolação da precipitação são necessários a fim de avaliar a melhor metodologia a ser aplicada.

Medidas de precipitação por sensores remotos, com resolução espacial de alguns quilômetros estão disponíveis a partir de 1998. Estas podem ser utilizadas de forma a acelerar as estimativas de evapotranspiração, tornando possíveis estimativas em tempo real do déficit hídrico de uma região.

Problemas de interpolação dos dados de solo são mais perceptíveis na época seca, quando a água armazenada no solo é crítica para a manutenção da evapotranspiração.

A substituição da floresta por áreas de pastagem reduz a capacidade de armazenamento de água, aumentando do déficit hídrico da bacia e prolongando o período de déficit. Também resulta em aumento do excedente hídrico no início das 
chuvas e por conseqüência, da descarga. Ocorre também a redução da evapotranspiração real da bacia.

A estimativa da evapotranspiração potencial pelo método empírico de Thornthwaite, juntamente com a utilização do balanço hídrico de Thornthwaite - Mather dentro de um sistema de informações geográficas mostrou-se viável, com resultados coerentes temporalmente e espacialmente.

A principal vantagem desta metodologia é a capacidade de estimar o balanço hídrico de uma bacia com erros relativamente pequenos, levando-se em conta a simplicidade do modelo e a necessidade de poucos dados de entrada, sendo de especial interesse para regiões com poucas informações. No entanto, esta não visa substituir os modelos mais complexos já existentes, sendo uma ferramenta complementar para a compreensão do balanço hídrico, de forma rápida e simples. 


\section{REFERÊNCIAS BIBLIOGRÁFICAS}

\section{AGÊNCIA NACIONAL DE ÁGUAS. HidroWeb, Sistema de Informações}

Hidrológicas. http://hidroweb.ana.gov.br/hidroweb/ (27.ago.2004).

BALLESTER, M.V.R.; VICTORIA, D. C.; COBURN, R.; VICTORIA, R.L.; RICHEY, J.E.; KRUSCHE, A.V.; LOGSDON, M.G.; MAYORGA, E.; MATRICARDI, E. Land use/cover of the Ji-Paraná river basin: building a GIS-based physical template to support the understanding of the biogeochemistry of surface waters in a mesoscale river in Western Amazonia. Remote Sensing of the Environment, v. 87, n. 4, p. $429-445$, Nov. 2003.

BIVAND, R.S. Using the R statistical data analysis language on GRASS 5.0 GIS database files. Computers \& Geosciences. v. 26, p. 1043-1052, 2000.

BOSH, J.M.; HEWLETT, J.D. A review of catchment experiments to determine the effect of vegetation changes on water yield and evapotranspiration. Journal of Hydrology, v. 55, p. 3 - 23, 1982.

BRUIJINZEEL, L.A. Predicting the hydrological impacts of land cover transformation in the humid tropics: the need for integrated research. In: GASH, J.H.C.; NOBRE, C.A; ROBERTS, J.M.; VICTORIA, R.L. (Ed.). Amazonian deforestation and climate. Chichester: John Wiley, 1996. cap. 2, p. $15-55$.

COCHRANE, T. T.; COCHRANE, T.A. SIGTERON: Sistema de Informação Geográfica para os terrenos e solos do Estado de Rondônia, Brasil (Software). Porto Velho: Tecnosolo, DHV Consultants, 1998

COSTA, M.H.; BOTTA, A.; CARDILLE, J.A. Effects of large-scale changes in land cover on the discharge of the Tocantins River, Southeastern Amazonia. Journal of Hydrology, v. 283, p. $206-217,2003$. 
CUlF, A.D.; ESTEVES, J.L.; MARQUES FILHO, A.O.; ROCHA, H.R. Radiation, temperature and humidity over forest and pasture in Amazonia. In: GASH, J.H.C.; NOBRE, C.A; ROBERTS, J.M.; VICTORIA, R.L. (Ed.). Amazonian Deforestation and Dlimate. Chichester: John Wiley, 1996. cap. 10, p. 175 - 191.

DUNNE, T.; LEOPOLD, L.B.. Water in environmental planning. New York: W. H. Freeman, 1978.818 p.

EMPRESA BRASILEIRA DE PESQUISA AGROPECUÁRIA. Sistema brasileiro de classificação de solos. Brasília: EMBRAPA, Centro Nacional de Pesquisa de Solos, 1999. $412 \mathrm{p}$.

ENVIRONMENTAL SYSTEMS RESEARCH INSTITUTE. ArcGIS Desktop, v. 8.1. (software) Redlands. 2001.

GASH, J.H.C.; NOBRE, C.A.; ROBERTS, M.J.; VICTORIA, R.L. Amazonian deforestation and climate. Chichester: John Wiley, 1996. 611 p.

GEOGRAPHIC RESOURCES ANALYSIS SUPPORT SYSTEM. GRASS GIS (software). http://grass.itc.it (12.fev.2002).

HANADA, L.C. Mudanças do uso da cobertura do solo na fronteira agrícola da Amazônia ocidental, bacia do Ji-Paraná - Rondônia. Piracicaba, 2004. 98 p. Dissertação (Mestrado) - Escola Superior de Agricultura "Luiz de Queiroz", Universidade de São Paulo.

HUNSAKER C.T.; LEVINE D.A. Hierarchical Approaches to the Study of Water Quality in Rivers. BioScience, v. 45, 193-203, 1995.

INTITUTO NACIONAL DE METEOROLOGIA. http://www.inmet.gov.br (15.jan.2004).

INSTITUTO NACIONAL DE PESQUISAS ESPACIAIS. Pre-LBA initiative CDROM data sets (compact disc). Cachoeira Paulista: CPTEC, 1998.

INSTITUTO NACIONAL DE PESQUISAS ESPACIAIS. Monitoring of the Brazilian Amazon forest by satellite 1999-2000. http://www.grid.inpe.br/amz/prodes2000/ (15.jan.2003). 
KERÉNYI, J.; PUTSAY, M. Investigation of land surface temperature algorithms using NOAA AVHRR images. Advances in Space Research, v. 26, n. 7, p 1077 - 1080, 2000 .

L'VOVICH, M.I.; WHITE, G.F.; BELYAEV, A.V.; KORONKEVIC, N.I.; LEE, T.R.; VOROPAEV, G.V. Use and transformation of terrestrial water systems. In: TUNER II, B.L.; CLARK, W.C.; KATES, R. W.; RICHARDS, J.F.; MATHEWS, J.T.; MEYER, W.B. (Ed.). The earth as transformed by human action. Global and regional changes in the biosphere over the past 300 years. New York: Cambrige University Press, 1995. p 233-252.

LEOPOLDO, P. R.; FRANKEN, W.; SALATI, E. Balanço hídrico de pequena bacia hidrográfica em floresta amazônica de terra firme. Acta Amazônica, v. 12, n. 2, p. $333-337,1982$.

LEOPOLDO, P.R.; FRANKEN, W.K.; VILLA NOVA, N.A. Real evapotranspiration and transpiration through a tropical rain forest in central Amazônia as estimated by the water balance method. Forest Ecology and Management. v. 73, p. 185 - 195, 1995.

LYRA, R.; SOUZA, S. S. de; FISCH, G. Comparação floresta pastagem através dos balanços à superfície, durante a estação seca. In: CONGRESSO BRASILEIRO DE Agrometeorologia, 10, Piracicaba, 1997. Anais. Piracicaba: SBA, 1997. p. $552-554$.

MEIXNER, F.X.; EUGSTER, W. Effects of landscape pattern and topography in emissions and transport. In: TENHUNEN, J.D.; KABAR, P. (Ed.). Integrating hydrology, ecosystem dynamics, and biogeochemistry in complex landscapes. New York: Wiley, 1999. p. 147- 175.

Nepstad, D. C.; CARVALHO, C.D. de; DAVIDSON, E.A.; JIPP, P.H.; LEFEBVRE, P.A.; NEGREIROS, G.H.; SILVA, E.D. da; STONE, T.A.; TRMBORE, S.E.; VIEIRA, S. The role of deep roots in the hydrological and carbon cycles of the Amazonian forest and pastures. Nature, v.372, p. 666 - 669, Dec. 1994. 
PAGOTO, D.S. Comportamento do sistema radicular do capim Tanzânia (Panicum maximum, Jacq.) sob irrigação e submetido a diferentes intensidades de pastejo. Piracicaba, 2001. 51 p. Dissertação (Mestrado) - Escola Superior de Agricultura “Luiz de Queiroz”, Universidade de São Paulo.

PEREIRA, A.R.; ANGELOCCI, L.R.; SENTELHAS, P.C. Agrometeorologia: fundamentos e aplicações práticas. Guaíba: Editora Agropecuária, 2002. 478 p.

POZO VAZQUES, D.; OLMO Reyes, F.J.; ALADOS ARBOLEDAS, L. A comparative study of algorithms for estimating land surface temperature from AVHRR data. Remote Sensing of the Envitonment, v. 62, p. 215 - 222, 1997.

R DEVELOPMENT CORE TEAM. R Foundation for Statistical Computing. R: A language and environment for statistical computing (software). Viena, 2004. http://www.r-project.org (12.mar.2003).

RIBEIRO, M.N.G.; VILLA NOVA, N.A. Estudos climatológicos da Reserva Florestal Duke, Manaus, AM. III. Evapotranspiração. Acta Amazônica, v. 9, n. 2, p 305 309, 1979.

SALA, O.E; CHAPIN III, F.S.; ARMESTO, J.J; BERLOW, E.; BLOOMFIELD, J.; DIRZO, R.; HUBER-SANWALD, E.; HUENNEKE, L.F.; JACKSON, R.B.; KINZIG, A.; LEEMANS, R.; LODGE, D.M.; MOONEY, H.A.; OESTERHELD, M.; POFF, N.L.; SYKES, M.T.; WALKER, B.H.; WALKER, M.; WALL, D.H. Global biodiversity scenarios for the year 2100. Science, v. 287, p. 1770-1774, 2000. SHARPLEY, A.N.; HEDLEY, M.J.; SIBBESEN, E.; HILLBRICHT-ILKOWSKA, A.; HOUSE, W.A.; RYSZKOWSKI, L. Phosphorus transfers from terrestrial to aquatic systems. In: TIESSEN, H. (Ed.). Phosphorus in the global environment. New York: John Wiley, 1995. p. 171-200.

SHUKLA, J; NOBRE, C.; SELLERS, P. Amazon deforestation and climate change. Science, v. 247, p. $1322-1325,1990$.

SENTELHAS, P.C.; PEREIRA, A.R.; MARIN, F.R.; ANGELOCCI, L.R.; ALFONSI, R.R.; CARAMORI, P.H.; SWART, S. Balanços hídricos climatológicos do Brasil 500 balanços hídricos de localidades brasileiras(compact disc). Piracicaba: ESALQ, 1999. 
SIMPSON, J.J.; GOBAT, J.I. Improved cloud detection for daytime AVHRR scenes over land. Remote Sensing of the Environment, v. 55, p. 21 - 49, 1996.

SWANK, W. T.; GROSSLEY, D. A. Forest hydrology and ecology at coweeta. New York: Springer-Verlag, 1988. 469 p.

TATEISHI, R.; AHN, C.H. Mapping evapotranspiration and water balance for global land surfaces. ISPRS Journal of Photogrametry \& Remote Sensisng, v. 51, p. $209-215,1996$.

THORNTHWAITE, C.W. An approach toward a rational classification of climate. Geographical Review, v.38, p.55-94, 1948.

THORNTHWAITE, C.W.; MATHER, J.R. The water balance. New Jersey: Drexel Institute of Technology, 1955. $104 \mathrm{p}$

TUCCI, C. E. M. Hidrologia: ciência e aplicação. Porto Alegre: Ed. da Universidade. ABRH, 1993.944p.

UNITED NATIONS ENVIRONMENT PROGRAMME. Vital water graphics. http://www.unep.org/vitalwater/resources.htm (12.ago.2004)

VICTORIA, D.C.; BALlESTER, M.V.R.; PEREIRA, A.R.; VILLA NOVA, N.A. Estimativa do balanço hídrico da bacia do Ji-Paraná (RO) através de sensoriamento remoto e geoprocessamento (compact disc). In: SIMPÓSIO BRASILEIRO DE SENSORIAMENTO REMOTO, 11, Belo Horizonte, 2003. Anais. São José dos Campos: INPE, 2003a. p.2693- 2647.

VICTORIA, D.C.; BALLESTER, M.V.R.; VICTORIA, R.L.; MARTINELLI, L.A. Estimativa das características do solo da bacia do Ji-Paraná (RO). In: CONGRESSO DE ECOLOGIA DO BRASIL, 6, Fortaleza, 2003. Anais. Fortaleza: Editora da Universidade Federal do Ceará, 2003b. p. 618 - 620.

VILLA NOVA, N.A.; SALATI, E.; MATSUI, E. Estimativa da evapotranspiração na Bacia Amazônica. Acta Amazônica, v.6, n. 2, p. 215 - 228, 1976.

VITOUSEK, P.M.; MELILLO, J.M. Nitrate losses from disturbed ecosystems. Science, v. 204, p. 469-474, 1979

WERTH, D.; AVISSAR, R. The local and global effects of Amazon deforestation. Journal of Geophysical Research, v. 107, n. D20, p. 8087, 2002. 
WERTH, D.; AVISSAR, R. The regional evapotranspiration of the Amazon. Journal of Hydrometeorology, v. 5, p. $100-109,2004$.

WILLMOT, C.J.; ROWE, C.M. Climatology of the terrestrial seasonal water cycle. Journal of Climatology. v. 5, p. 589 - 606, 1985.

WRIGTH, I.R.; GASH, J.H.C.; ROCHA, H.R. da; ROBERTS, J.M. Modeling surface conductance for Amazonian pasture and forest. In: GASH, J.H.C.; NOBRE, C.A; ROBERTS, J.M.; VICTORIA, R.L. (Ed.). Amazonian deforestation and climate. Chichester: John Wiley, 1996. cap. 26, p. $437-458$.

ZIEGLER, A.D.; GIAMBELLUCA, T.W.; TRAN, L.T; VANA, T.T.; NULLET M.A.; FOX, J.; VIEN, T.D.; PINTHONG, J.; MAXWELL, J.F; EVETT, S. Hydrological consequences of landscape fragmentation in mountainous northern Vietnam: evidence of accelerated overland flow generation. Journal of Hydrology, v. 287, n. 1/4, p. $124-146$, Feb. 2004. 